\title{
Massage to prevent pressure ulcers: Knowledge, beliefs, practice and effectiveness
}

Citation for published version (APA):

Peeters-Duimel, I. G. P. (2005). Massage to prevent pressure ulcers: Knowledge, beliefs, practice and effectiveness. [Doctoral Thesis, Maastricht University]. Maastricht University. https://doi.org/10.26481/dis.20051215ip

Document status and date:

Published: 01/01/2005

DOI:

10.26481/dis.20051215ip

Document Version:

Publisher's PDF, also known as Version of record

\section{Please check the document version of this publication:}

- A submitted manuscript is the version of the article upon submission and before peer-review. There can be important differences between the submitted version and the official published version of record.

People interested in the research are advised to contact the author for the final version of the publication, or visit the DOI to the publisher's website.

- The final author version and the galley proof are versions of the publication after peer review.

- The final published version features the final layout of the paper including the volume, issue and page numbers.

Link to publication

\footnotetext{
General rights rights.

- You may freely distribute the URL identifying the publication in the public portal. please follow below link for the End User Agreement:

www.umlib.nl/taverne-license

Take down policy

If you believe that this document breaches copyright please contact us at:

repository@maastrichtuniversity.nl

providing details and we will investigate your claim.
}

Copyright and moral rights for the publications made accessible in the public portal are retained by the authors and/or other copyright owners and it is a condition of accessing publications that users recognise and abide by the legal requirements associated with these

- Users may download and print one copy of any publication from the public portal for the purpose of private study or research.

- You may not further distribute the material or use it for any profit-making activity or commercial gain

If the publication is distributed under the terms of Article $25 \mathrm{fa}$ of the Dutch Copyright Act, indicated by the "Taverne" license above, 
Massage to prevent pressure ulcers: Knowledge, beliefs, practice and effectiveness. 
15BN-10: 9090200479

ISBN-13: 9789090200477

Copyright @2005 Inge G.P. Duimel-Peeters, Maastricht

Vormgeving: Hans Duimel

Druk: Drukkerij Duplica

Illustratie omslag: Linda Dirix 


\section{Massage to prevent pressure ulcers:}

Knowledge, beliefs, practice and effectiveness.

PROEFSCHRIFT

Ter verkrijging van de graad van doctor aan

de Universiteit Maastricht,

op gezag van de Rector Magmificus,

Prof. Mr. G.P.M.F. Mols,

volgens het besluit van het College wan Decanen.

in het openbaar te verdedigen

op donderdag 15 decerriber 2005 om 12.00 uur

door

Inge G.P. Duimel-Peeters

geboren te Tongeren (B) op 9 september 1974 . 
Promotores:

Prof dr. M.P.F. Berger

Prof. dr. L.H.E.H. Snoeckx

Copromotor:

dr. R.J.G. Halfens

Beoordelingscommissle:

Prof. dr. R.A. de Bie (voorzitter)

Prof. dr. TW.N. Dassen (Charité Universität, Berlin, Germany)

dr. ir. C.W.J. Oomens (Technische Universiteit Eindhoven)

Prof. dr. J.M.G.A. Schols

Prof. dr. R. De Wit

Printing of this thesis was financially supported by Euro Tec BV and ZonMw. 


\section{Contents}

CHAPTER 1

Introduction 7

CHAPTER 2

The effects of massage as a method to prevent pressure ulcers. A review of the literature. 27

\section{CHAPTER 3}

A systematic review of the efficacy of topical skin application of Dimethyl Sulfoxide on wound healing and as an anti-inflammatory drug. 47

\section{CHAPTER 4}

Massage to prevent pressure ulcers: knowledge, beliefs and practice. A cross-sectional study among nurses in the Netherlands, in 1991 and 2003. 63

\section{CHAPTER 5}

Policy, knowledge and practice of massage to prevent pressure ulcers in relation to the Dutch prevalence rates. 79

\section{CHAPTER 6}

The effectiveness of massage with and without Dimethyl Sulfoxide in preventing pressure ulcers: A randomized, double blind cross-over trial in patients prone to pressure ulcers. 93

CHAPTER 7

General Discussion 117

SUMMARY 129

SAMENVATTING 133

DANKWOORD 137

CURRICLLLM VITAE 139 


\section{chapter 1}

| |ntroduction | 
P ressure ulcers, also commonly referred to as bedsores, pressure sores, decubitus ulcers or simply decubitus, can develop when sustained pressure, friction or shear is applied to specified areas of the body, in turn leading to degeneration of the skin and the underlying soft tissues: ${ }^{(1)}$ As the name bedsores or decubitus ulcers (from Latin decumbere, to lie down) suggests, compression of the skin and deeper tissues between the hard, bony skeleton and the unylelding surface of a bed is the most common situation, but not the only condition initiating pressure ulcers. ${ }^{[2)}$ Sitting in a wheelchair or a regular seat, or wearing a prosthesis or orthosis can also cause pressure ulcers. In general, any situation im which a body area is subjected to continuous, unrelieved pressure can lead to the development of pressure ulcers.

In the Netherlands as in other countries, pressure ulcers are still a major problem in institutions for health care services. ${ }^{(3)}$ Estimations for 1998 revealed that more than $1 \%$ of the national health care budget was spent on prevention and treatment of pressure ulcers. ${ }^{(4)}$ These ulcers are a common and painful condition and cause a great deal of suffering and frustration, not only to patients themselves but also to their relatives and caregivers. ${ }^{(5)}$ Pressure ulcers can greatly extend the length of hospitalisation and can, in extreme conditions, even contribute to death. ${ }^{2 y}$

Until now, various treatments have been applied to prevent pressure ulcer development such as special mattresses, pressure-relieving cushions, repositioning schemes and nutritional support by a dietician. One of the methods which is also practised (whether or not in combination with other treatments) is massage. However, massage stopped being recommended as a preventive method as early as the $19805^{(6.9)}$ National and intermational guidelines regard massage as a method that could cause injuries to the skin. 6.10 . Some authors even believe that massage actually provokes the development of pressure ulcers. (11. Nevertheless, research in Dutch health care institutions has found that almost all hospital nurses regarded the use of massage as a very effective preventive method. (13) The same opinions were held by health care workers in Dutch nursing homes. ${ }^{14.15)}$ Although current guidelines advise against massage as a preventive method, it is essentially unknown whether massage is effective or not in preventing the development 
of pressure ulcers. There are still some persistent, contradictory beliefs about the use and benefits of massage in guidelines, practice and the literature. ${ }^{(16)}$

Various theories have been forwarded to explain the aetiology of pressure ulcers, with most experts adhering to the theory that pressure ulcers result from chronic occlusion of capillary blood flow, leading to alternating periods of ischemia and reperfusion in the compressed tissue. Recently, it was shown in experimental animals that pressure ulcers can indeed develop as a consequence of ischemia-reperfusion injury, with toxic oxygen radicals apparently acting as important mediators in the pathogenesis of pressure ulcers. ${ }^{(7)}$ However, it should be noted these experiments were performed on healthy animals that had not previously suffered from vascular insult5.(18) Other studies with experimental animals found that the oral intake of antioxidants to inactivate the axygen radicals had a preventive effect on the development of skin ulceration. ${ }^{(19)}$ Dimethyl sulfoxide (DMSO) is such a powerful, highly active scavenger of oxygen radicals, especially of the hydroxyl radical, and penetrates easily through the skin and other biomembranes. In concentrations below $50 \%$ it is not toxic. 20.21$)$

The research on which this thesis reports focussed on the effects of massage, whether or not in combination with DMSO, as a treatment to prevent the development of pressure ulcers in elderly patients.

Before discussing this aspect, this introduction outlines the physiology and blood supply of the healthy skin, and the available knowledge about the aetiology and pathogenesis of pressure ulcers. Finally it elaborates on the three main aspects of this thesis: the use of massage, the influence of DMSO and the specific features of nursing homes residents i.e. the elderly.

\section{I prysiology of the skin}

The skin constitutes the outer boundary between the human body and the erwironment, and functions both as a barrier and a connection between the outer world and the internal organs. ${ }^{(22)}$ In an adult person, the skin accounts for $16 \%$ of the total body weight, and has a total surface of $1.2-2.3 \mathrm{~m}^{2}$. $23 \times 2 \mathrm{k}$. it is the largest organ in the body and has many crucial tasks, as summarized in Table 1. 
- Maintenance of the body temperature through vasodilatation and constriction of the surface blood vessels.

- Protection from friction and shear, dehydration, ultraviolet light and radiation.

- Perception of temperature and pain.

- Perception of pressure, touch and vibration (collectively: tactile sensations).

- Excretion of small amounts of salts and perspiration (to aid thermal regulation).

- Synthesis of vitamin D.

- Prevention of loss of water and electrolytes.

Structurally, the skin consists of three layers; the epidermis, the dermis and a subcutaneous layer (see Figure 1 on the inside of the cover). The epidermis contains stratified squamous epithelium, keratinocytes, melanocytes, Langerhans cells and Granstein cells, and can be divided into five layers. ${ }^{(25)}$ The deepest layer is the stratum basale or stratum germinativum (1) which consists of basophilic columnar or cuboid epithelial cells, resting on the dermal-epidermal junction which separates the dermis from the epidermis. Together with the adjacent stratum spinosum, it constantly produces new cells. Aside from this, the stratum spinosum (2) provides resistance to mechanical disruption and contains nerve endings for sensation and touch. The stratum granulosum (3) contains keratocytes which provide colour to the epidermis and render it waterproof through the presence of keratohyatin. The stratum lucidum (4) is made up of several clear, flat dead cells, and is found only on the palms of the hands and the soles of the feet where the skin reaches its greatest thickness. Finally, the stratum corneum (5) consists of 25 - 30 layers of closely packed dead cells. These cells contain keratin and are constantly shed at a 27-day turnover rate. This layer is tough and waterproof and acts as a barrier to bacteria and chemicals.24-27)

The underlying dermis or corium consists of two layers; the upper stratum or stratum papillare (1) and the deeper layer or stratum reticulare (2).26) 
Essentially it is a thick layer of strong connective tissue containing blood vessels, nerves, glands and hair follicles. It is connected to the epidermis by connective tissue. (25)

Going further inward, the dermis changes into the subcutis without a clearly defined boundary. The entire subcutis contains adipase tissue, the purpose of which is to isolate the body and to cushion. 2.25

\section{3 | Blood supply of the skin}

The distribution of blood vessels in the skin parallels the layered structure of this organ. From the arteries lying under the subcutaneous tissue, mumerous vessels arise which form a cutaneous plexus between the subcutaneous plexus and the dermis. Wherever the skin is more mobile, the vessels take a pronounced tortuous course. The individual arterioles run outwards perpendicularly to the deep cutaneous plexus. At the foot of the papillary layer they branch into the subpapillary plexus. Very fine loop-like capillaries extend from there into the papillae of the dermis and thus ensure perfusion of the epidermis. Figure $2^{22 x}$ (on the inside of the cover) shows a schematic diagram of the blood supply to the skin.

The vascular circulation can be classified into three distinct systems: segmental, perforator, and cutaneous circulation. ${ }^{(18)}$ The segmental system comprises the body's main distributing vessels stemming from the aorta. Nutritional blood supply to the muscle is provided by the perforator system. The third, cutaneous system, consists of the supplying arteries, capillary beds, and drainage veins in the skin. In addition to providing the skin with metabolic substrates and removing its waste products, the cutaneous systiem also plays an important role in the thermoregulation of the body. In relation to its metabolic meeds, the skin is actwally oversupplied with blood.")

4 | Aetiology and pothogenesis of pressure ulcers

4.11 The grading and prevalence of pressure ulcers.

The European Pressure Ulcer Advisory Panel (EPUAP) defines a pressure ulcer as an area of local damage to the skin and underlying tissue caused by 
pressure, shear and/or friction or a combination of all these factors. Clinically, pressune ulcers most often appear in the tissues cowering bony prominences. Studies in animals have shown that muscle and subcutaneous tissue are more susceptible to pressure-induced injury than the epidermis. The EPUAP has classified pressure ulicers into grades I-IV (see Figure 3 on the inside of the cover). Whis grading system is based on a clinical description of the severity of the localised damage which is due to pressure, shear or friction, and says nothing about the cause, the duration, the aetiology or the pathogenesis. Agreement on the grading of the severity of pressure ulcers is important for treatment and research, and for scoring prevalence and incidence rates. Therefore management should be based on a uniform classification.

In 2004, the general prevalence rate of pressure ulcers in Dutch health care institutions ranged from $14.2 \%$ to $30.5 \%$. Nursing homes had the poor est results with a prevalence rate of $30.5 \%$. In this environment pressure ulcers developed most frequently at the coccyx (27.8\%) and the heels $(33.8 \%)$

\subsection{Aetiology of pressure ulcers}

In addition to pressure, shear and friction, other misk factors can also affect patients" susceptibility to pressure ulcers. 32 Such factors are sensory perception, level of activity and mobility and factors affecting tissue tolerance such as moisture, nutrition, and friction and shear. These factors are also included as subscales in the Braden scale, a tool for evaluating the pressure ulcer risk. ${ }^{(3)}$ At present, it is generally accepted that mechanisms underlying the aetiology of pressure ulcers are rather complex and still not fully understood. What nurses and other care professionals know about the factors causing pressure ulcers is very often restricted to the extrinsic and external influences. The main extrinsic factors leading to tissue damage are pressure, friction and shear forces and the duration of these forces. 30) However, it is well established that pressure ulcers can also be provoked by such intrinsic factors as the level of blood supply and lymphatic drainage. reperfusion injury and cellular defomation. "other" more individualy deter- 
mined intrinsic factors also increase the vulnerability to pressure ulcer development, such as general health, reduced mobility, reduced activity, body weight, incontinence and nutrition level. ${ }^{(1.25 .32 .37 .42)}$ Finally, external factors such as long trolley waits in emergency departments, hard chairs, immobilization with traction, poor positioning and poor lifting techniques can affect the development of pressure ulcers. ${ }^{225,3.35}$

\section{3 | Pathophysiology of pressure ulcers}

Several theories have been proposed to explain how compressive tissue straining leads to local cell damage. ${ }^{(43)}$ The three main hypotheses on how mechanical load leads to tissue damage are the following:

1. Poor blood supply and Bymphatic drainage:

It is well known that pressure and immobility leads to the continuous compression of venous blood vessels and, consequently, to reduced blood flow in the compressed tissue. As a result, cells receive less oxygen and are unable to remove their waste products, ultimately leading to irreversible cell damage. In addition, the lymphatic system is compromised by immobility and by excessive mechanical stress, so that the tissues are not adequately drained.

\section{Reperfusion injury:}

A more recent hypothesis, mainly based on results obtained with experimental animal models, is that post-ischemic reperfusion leads to tissue damage through the enhanced local production of oxygen free radicals. ${ }^{\mid r .}$. wes) These radicals arise in the cells and are responsible for cell damage since they degrade membrane lipids. Tissue injury also increases with an increasing number of total ischemia-reperfusion cycles, the duration of the ischemia and the frequency of ischemia-reperfusion cycles. $\left.{ }^{\text {* }}, 47\right]$

3. Cell deformation:

Another recent hypothesis concentrates upon cellular deformation. Continuous excessive deformation of the cell triggers a variety of effects which may be involved in early cell damage, such as local membrane stresses 
which may lead to buckling and bursting of the membrane, volume changes and modifications of the cytoskeletal organisation affecting the cell's integrity. ${ }^{(42)}$ Hence, the cause of cell damage could be a direct consequence of sustained cell deformation or of impaired transport of both metabolites and waste products withir the cell and in the surrounding tissue. (4a) Nevertheless, the relationship between local cell damage and the load magnitude and time is still unclear. ${ }^{(45)}$

\subsection{Development of pressure ulcers}

Two theories have been postulated to explain the site-specific development of pressure ulcers. According to the traditional so-called top-down theory, pressure ulcers are initiated in the epidermis, and later expand into deeper lying tissues. In contrast, the bottom-up approach presumes that the pressure ulcer starts in the deeper tissue layers, in close proximity to the bone. This would imply that microcirculatory changes in the deeper tissue layers are more deleterious than what can be perceived on the skin surface $\{0.51\}$

The top-down theory states that the most striking effect of pressure ulcers, starting from grade I, is the irreversible redness, also called the nonblanchable erythema. As continuous compression occludes tissue blood flow, interferes with lymphatic circulation and deprives the tissues of oxygen, nutrients and waste removal(5a), cells produce toxic metabolites, leading to tissue acidosis, increased capillary permeability, oedema and finally cell death resulting in a non-infectious inflammation reaction." "522) Finally, the skin tums red and feels warmer. This theory is supported by experimental findings that relate skim blood flow to the level of externally applied pressure. When the latter exceeds the nomal capillary blood pressure (32 $\mathrm{mmHg}$ or $4.27 \mathrm{kPa}$ ), fluid leakage from the vessells into the extracellular space will initiates oedema. ${ }^{(53)}$ This oedema further hampers proper circulation, so that tissue pressure will continues to increase. Eventually, haemorrhage develops, which is responsible for the non-blanchable redness of the skin. ${ }^{(5)}$ If pressure is relieved in time and perfusion of the tissues can be restored, such that toxic metabolic waste products are adequately removed, the redness may disappear. This situation is known as blanchable erythema. $52 ;$ 
The bottom-up approach assumes that the skin is less sensitive to pressure-induced damage than the underlying deeper thssues. When blood flow in the deep layers is interrupted, muscle tissue can be damaged." The combination of prolonged pressure and blood flow deficit can cause ischema of the skin tissue and non-blanchable redness of the skin will appear. The interruption of the blood flow in the deeper layers irreversibly damages muscle tissue and the circulation to superficial layers becomes permanently deteriorated. If damage to the deeper underlying tissues is far advanced. sclerosis of the necrotic tissue can also be detected through palpation. ${ }^{563}$ Such deep ulcers arising in the deep muscle layers covering bony prominences are very harmful, develop at a faster rate than superficial ulcers and yleld more extensive ulceration.

\section{The use of massage}

The natural human response to pain in the skin or underlying tissue is to use touch to alleviate it. Based upon this knowledge, the art of massage has been deweloped long ago. Indeed, it is described in writings dating from before 2000 B.C." ${ }^{(1,5)}$ However, some physiological and therapeutic effects of massage are still being questioned, especially regarding its use as a preventive treatment for the development of pressure ulcers. The purpose of the present thesis was to gain a better insight into the role of massage in the pressure ulcer problem, especially among the elderly. The project started with a literature study, which intended to summarize the state of the art regarding the effects of different massage techniques. Furthermore, it identified the most important general indications and contra-indications for massage, and summarized these for application in patients prone to developing pressure ulcers.

6 Imfluence of radical scavengers

In tissue affected by pressure ulcers, like any tissue in which inflammation occurs, repetitive ischemia-reperfusion episodes can lead to the local forma- 
tion of reactive oxygen species. Briefly, leukocytes are recruited during the reperfusion process after an ischemic event, for instance secondary to excessive tissue pressures. Adhesion molecules are expressed by the endothelial surface, and the leukocytes roll, stick and migrate into the tissue. There they express pro-inflammatory cytokines and release destructive free radicals. ${ }^{\text {(59) }}$ At the cellular level, the release of oxidants is a stress event and aged cells are less equipped to deal with these events than non-aged cells. ${ }^{\text {[2i] }}$ The main representatives of these radicals are the super oxide anion $\left(\mathrm{O}_{2}^{-}\right)$, hydrogen peroxide $\left(\mathrm{H}_{2} \mathrm{O}_{2}\right)$ and the hydroxyl radical $\left(\mathrm{OH}^{-}\right)$. Since dimethyl sulfoxide (DMSO; $\left(\mathrm{CH}_{3}\right)_{2}$ S-O) is known to be a hydroxyl-inactivating compound, it can be assumed that its beneficial effects on pressure ulcers are based upon the inactivation of the hydroxyl radical.

Besides to be a water-white to straw-yellow organic liquid, DMSO is a colorless, oily substance with a smell of sulphur and a slightly bitter taste. In topical application this simple, highly polar chemical compound thas been found to alleviate local ischemic damage in several experimental amimal models. ${ }^{(60.61)}$ In addition to its analgesic effect, the most important property of DMSO is the enhancement of percutaneous penetration, 50 that it is often used as a carrier for active drug-containing creams. ${ }^{(2)}$

The use of DMSO in preventing pressure ulcers is rather recent in spite of the fact that the compound is a well-known agent in physiotherapy and dermatology. Indeed, DMSO is known for its anti-inflammatory, wound-healing and pain-relieving effect5. ${ }^{(20)}$ Based on the knowledge that DMSO has an antiinflammatory operating mechanism, a pilot study ${ }^{(62)}$ was set up in elderly patients to investigate any beneficial effect of DMSO to prevent the development of pressure ulcers. This pilot study revealed that rubbing the intact skin with a DMSO-containing cream during the first stage of pressure ulcers (according to EPUAP's four grade system) led to a decrease in pressure ulcer occurrence among high risk patients. Based on this pilot study and a literature study about the effects of DMSO, we initiated a subclinical trial to evaluate the effects of a DMSO-containing cream on the development of pressure ulcers in patients prone to them. 


\section{$7 \mid$ Pressure ulcers in the elderly}

For the studies described in the present thesis, only patients of Dutch nursing homes were invited to participate because in the Netherlands they have the highest prevalence rates of pressure ulcers and the population is rather stable over a long period. ${ }^{(63)}$ The high prevalence rates in this population can partly be explained by the age-related changes to the skin, such as the loss of dermal vessels, thinhing of the epidermis, flattening of the dermalepidermall junction, loss of elastic fibres and increased skin permeability, and increased susceptibility to skin breakdown. ${ }^{(2)}$ It also seems that wound-healing impairment is additive, if not synergistic, when age and ischemia are combined. (59) Aged cells show a decreased proliferative capacity with prolonged doubling times and eventual replicative senescence. These changes most likely affect the altered stress response in the aged and play a role in chronic wounds ${ }^{(59)}$

81 Aims and outline of this thesis

In this dissertation, the beliefs and knowledge about massage among Dutch nurses and health care givers, their use of this treatment and its effectiveness in preventing pressure ulcers have been investigated. The aim of this thesis is to clarify the existing discrepancy between theory and practice regarding the use of massage as a preventive method for pressure ulcers in the Netherlands. Therefore, this thesis consists of two parts. In the first part, we describe results obtained from literature studies on the effects of different massage-techniques and on the efficacy of topical skin application of DMSO. The second part presents and discusses the results of our empirical studies. The beliefs and the knowledge about and the use of massage were investigated in the light of the current guidelines. Furthermore, it was also investigated if relations exist between these three aspects and the pressure ulcer policy of individual institutions on the one hand, and institutional prevalence rates on the other hand. Finally, the effectiveness of massage - whether or not in combination with DMSO - was investigated by means of an R.C.T. in patients of Dutch nursing homes. 


\section{PART 1 | Literature studies}

\section{Chapter 2}

Well-controlled studies of the preventive effects of massage on the development of pressure ulcers in a geriatric population are scarce. Therefore, we performed a literature study, in order to survey the existing knowledge about the general effects of skin massage. The chapter reports on indications and/or contra-indications for the application of massage in patients prone to pressure ulcers, both in general and more specific terms.

\section{Chapter 3}

In a systematic review we investigated the present state of knowledge regarding the use of DMSO in the prevention of pressure ulcer development. This chapter reports the results of our evaluation with respect to wound healing and anti-inflammatory effects of different concentrations of DMSO, administered by topical application to the skin.

\section{PART 2 I Empirical results}

\section{Chapter 4}

To assess nurses' current knowledge and beliefs about massage to prevent pressure ulcers, and their use of this treatment, a study was designed to evaluate the changes in these three aspects after the publication of the 2002 Dutch national guidelines. We compared the outcome of this study with the situation in 1991, the year in which the previous guidelines and nurses knowledge, beliefs and practice were investigated. This enabled us to determine whether any changes had occurred between 1991 and 2003.

\section{Chapter 5}

This chapter reports on a study that further elaborated on the results described in chapter 4 . The aim of this study was to find out whether or not the pressure ulcer policy of individual institutions was related to the nurses' knowledge and their use of massage, and to the prevalence rate of pressure ulcers in each institution. To this end, data were analysed at an aggregated 
level by incorporating results and investigated characteristics as described in the National Prevalence Study of Pressure Ulcers 2003, the results of which were obtained from inquiries in the same institutions and wards, as described in chapter 4. Eventually, the evaluation of the results drawn on individual level (micro-level) was related to the results found in the anmul Dutch national prevalence survey of 2003 at institutional level (macro-level). At the micro-level, we analysed the nurses knowledge about massage and their use of it in practice, whereas at the macro-level we included the institutions' prevalence rates and PU policy features.

\section{Chapter 6}

The purpose of the study described in this chapter was twofold. In a wellcontrolled randomized clinical trial on patients prone to pressure ulcers, we evaluated the effects of massage in the prevention of pressure ulcers by comparing massage treatment with a treatment that only consisted of a regular body position changes. Secondly, we evaluated the effects of massage in combination with a DMSO-containing cream on the incidence of pressure ulcers. This chapter reports the main findings of this clinical trial and discusses the effects of massage, with and without: DMSO, as a method to prevent pressure ulcer development.

\section{Chapter 7}

Chapter 7 presents the final conclusions of this thesis and elaborates on several theoretical and methodological issues. Furthermore, it presents recommendations for further investigations and for the daily practice of preventing pressure ulcers.

The chapters in this thesis, with the exception of chapters 1 and 7, are all based on articles published in or submitted to scientific journals. Since this implies that they were all intended to be read independently, some overlap between the chapters is inevitable. 


\section{$10 \mid$ References}

1. Maklebust J. Pressure Ulicers: Etiology and Prevention. Nursing Clinics of North America 1987;22:359-77.

2. Torrance C. Pressure sores. 1: Pathogenesis. Nursing Times 1981;77(3, supplement): $1-4$

3. Bours GJUW. Halfens RJG. Huijer Abu-Saad H, Grol RTPM. Prevalence, prevention and treatment of pressure ulcers: A descriptive study in 89 institutions in The Netherlands. Research in Nursing and Health 2002:25(2):99-110.

4. Severens JL, Habraken JM, Duivenvoorden S, Frederiks CMA. The cost of illness of pressure ulcers in the Netherlands. Advances in Skin \& Wound Care 2002;15(2):72-7.

5. Bours GJJW. Pressure Ulcers: Prevalence measurements as a tool for improving care [PhD-Thesis]. Maastricht: Universiteit Maastricht; 2003.

6. AHCPR, Research AfHCPa. Pressure ulcers in adults: prediction and prevention. Clinical Practice Guideline no. 3: U.S. Department of Health and Human Services, Public Health Service, Agency for Health Care Policy and Research; 1992 May 1992. Report No: 92-0047.

7. CBO, Toetsing CBvdl. Herziening decubitusrichtlijnen. (Revision of pressure ulcer consensus). Utrecht: Centraal Begeleidingsorgaan voor de Intercollegiale Toetsing: 1992 juni.

8. CBO, Toetsing CBvdl. Richtijn Decubitus. (Pressure ulcer guidelines). Utrecht: Centraal Begeleidingsorgaan voor de Intercollegiale Toetsing; 2002.

9. EPUA.P. Pressure ulcer prevention guidelines. In: EPUAP; 1998.

10. NPUAP. Statement on pressure ulcer prevention. Silver Spring, MD: AHCPR: 1992.

11. Buss IC, Halfens RJG, Huijer-Abu Saad H. The effectiveness of massage in preventing pressure sores: a literature review. Rehab Nurs $1997 ; 22(5): 229-34$

12. Dyson R. Bed sores: the injuries hospital staff inflict on patients. Nursing Mirror 1978:146(24):30-2. 
13. Halfens RJG, Eggink M. Knowledge, beliefs and use of nursing methods in preventing pressure sores in Dutch hospitals. International Jourmal of Nursing Studies 1995;32(1):16-26.

14. Buss IC. Halfens RJG. Knowledge of (enrolled) nurses working in Dutch nursing homes about pressure sores prevention: introduction [poster]. In: EPUAP, editor. Education: experiences we can share: 5th European Pressure Ulcer Advisory Panel open meeting; 2001 September 27-29, Le Mans, France.

15. Buss IC. Halfems RJG. Huyer Abu Saad H, Kok G. Pressure ulcer prevention in mursing homes: views and beliefs of enrolled murses and other health care workers. Journal of Clinical Nursing 2004:13:668-676.

16. Duimel-Peeters IGP, Halfens RJG, Berger MPF, Snoeckx LHEH. The effects of massage as a method to prevent pressure ulcers. A review of the literature. Ostomy/Wound Management 2005;51(4):70-80.

17. Houwing RH. Overgoor M. Pressure-induced skin lesions in pigs: reperfusion injury and the effects of vitamin E. J Wound Care 2000:9(1):3640 .

18. Cherry GW, Ryan TJ. Pathophysiology. In: Parish LC, Witkowski JA, Crissey JT, editors. The Decubitus Ulcer in Clinical Practice. Germany: Springer; 1997.

19. Hajarizadeh $H_{\text {s }}$ Lebredo L, Barrie $R$, Woltering EA. Protective effect of doxorubicine in vitamine $C$ or dimethyl sulfoxide against skin ulceration in the pig. Amnals of Surgical Oncology 1994:1(5):411-14.

20. Duimel-Peeters IGP, Houwing RH, Teunissen CP, Berger MPF, Snoeckx LHEH, Halfens RJG. A systematic review of the efficacy of topical skin application of Dimethyl Sulfoxide on wound healing and as an anti-inflammatory drug. WOUNDS (A Compendiurn of Clinical Research and Practice) 2003;15(11):361-70.

21. Sulzberger MB, Cortese TA, Fishman L. Some effects of DMSO on human skin in vivo. Ann NY Acad Sci 1967:141(1):437-50.

22. Hartmann P. Compendium Wounds and Wound Management. Heldenheirn: Paul Hartmann AG: 2003.

23. Despopoulos A, Silbernagl 5. Color A.tlas of Physiology. New York: 
Thieme Medical Publishers: 1991.

24. Junqueira LC. Cameiro J. Kelley RO. Functionele Histologie (Basic Histology). Maarssen: Elsevier/Bunge; 1998.

25. Russell L. Physiology of the skin and prevention of pressure sores. Br J Sports Ved 1998:7:10841100.

26. Asmussen P, Söliner B. De huid. Meer dan een handig jasje. (The skin is more than a convenient jacket). Nursing 96:1996:60-3.

27. Oomens CWJ. A mixture approach to the mechanics of skin and subcutis. Helmond: dissertatiedrukkerij Wibro: 1985.

28. EPUAP. Pressure ulcer treatment guidelines. In: EPUAP: 1998.

29. Allman RM. Pressure ulcers among the elderly. The New England Journal of Medicine 1989:320(13):350-3.

30. EPUAP. Four-grade system. In: European Pressure Ulcer Advisory Panel; 1998 September 20-22; Oxford, UK: 1998.

31. Halfens RJG, Janssen MAP. Meljers JMM, Wansink SW. Landelijke Prevalentiemeting decubitus en andere zorgproblemen: herziene resultaten zevende jaarlijkse meting 2004. (National Prevalence survey pressure ulcers and other health care problems). Unversiteit Maastricht, Dep. Health Care Studies / Section Nursing Science, Maastricht 2005.

32. Kosiak M. Etiology of Decubitus Lllcers. Arch Phys Med Rehabil $1961: 119-29$

33. Clark S. Critical factors of pressure ulcer development, Journal of District Nursing 2003;17(6):26-30.

34. Horsley JA, Crane J, Haller KB. Bingle JD. Preventing decubitus ulcers: CURN project. New York: Grune \& Stratton: 1981.

35. Reuler JB. Cooney TG. The pressure sore: pathophysiology and principles of mamagement. Ann Intern Med 1981;94(5):661-6.

36. Goossens RHM. Klinisch fysische aspecten wan decubitus. (The clinical and physical aspects of pressure ulcers). Klinische Fysica 1995(3):21-4.

37. Bergstrom N. Braden BJ, Laguzza A, Holman $V$. The Braden scale for predicting pressure sore risk. Nursing Research 1987:36(4):205-10.

38. Berlowitz DR. Wiking SVB. Risk factors for pressure sores: a comparison of cross-sectiomal and cohort-derived data. JAGS 1989;37(11):1043-50. 
39. Braden B.l. Bergstrom N. A conceptual scheme for the study of the etio logy of pressure sores. Rehabilitation Nursing 1987:2(1):8-12.

40. Mathus-Vliegen EMH. Nutritional status, nutrition and pressune uleers. Nutr Clin Pract 2001;16:286-91.

41 Schols, JMGA, de Jager-vid. Ende MA. Nutritional interwention in pres sure ulcer guidelimes: an inventory. Nutrion $2004 ; 20(6): 548-53$.

42. Defloor T. The risk of pressure sores: a conceptual scheme. Jaumal of Clinical Nursing 1999:8(2):206-16.

43. Breuls RGM. Experimental and Theoretical Analyses of Compression Induced Muscle Damage. Aetiological factors in pressure ulcers [Thesis]. Eindhoven: Technische Universiteit Eindhoven; 2003.

44. Bader DL, Bamhill RL, Ryan TJ. Effect of externally applied skin surface forces on tissue vasculature. Arch Phys Med Rehabil 1986;67:807-811.

45. Reddy NP. Effects of mechanical stresses on lymph and interstitial fluid flows. In: Bader DL, editor. Pressure sores - clinical practice and scientific approach. London: Macmilan Scientific and Medical; 1990.

46. Peirce SM, Skalak TC, Rodeheaver GT. Ischemia-reperfusion injury in chronic pressure ulcer formation: a skin model in the rat. Wound Repair and Regeneration 2000;8(1):68-76.

47. Herman EC, Kmapp CF, Donofrio JC, Salcido R. Skin perfusion responses to surface pressure-induced ischemia: implication for the developing pressure ulcer. Journal of Rehabilitation Research and Development. 1999;36(2):109-20.

48. Swain 1. Bader DL. The measurement of interface pressure and its role in soft tissue breakdown. In: Clark M, editor. Pressure Ulcers: Recent advances in tissue wiability. Wiltshire: Quay Books MA Healthcare Limited; 2004.

49. Breuls RGM, Bouten CVC, Oomens CWJ, Bader DL, Baaijens FPT. Compression induced cell damage in engineered muscle tissue: an in vitro model to study pressure ulcer aetiology. Anmals of Biomedical Engineering 2003:31(11):1357-64.

50. Schubert W. Perbeck L, Schubert PA. Skin microcirculatory and thermal changes in elderly subjects with early stage of pressure sores. Cinical 
Physiology 1994:14(1):1-13.

51. Maklebust JA, Sleggreen MY. Pressure ulcers: guidelines for prevention and nursing management. 2nd ed. ed. Springhouse: Springhouse. Corporation; 1996.

52. Parish LC. Witkowski JA, Crissey JT, editors. The decubitus ulcer in clinical practice. Berlin; Heidelberg; New York: Springer; 1997.

53. Bouten CV, Oomens CW, Baaijens FP, Bader DL. The etiology of pressure ulcers: skin deep or muscle bound? [commentary]. Archives of Physical Medicine and Rehabilitation 2003;84(4):616-9.

54. Alterescu V. Etiology and treatment of pressure ulcers. Decubitus 1988:1(1):24-8.

55. Allman RM. Pressure ulcer prevalence, incidence, risk factors, and impact. Clinics in Geriatric Medicine 1997:13(3):421-36.

56. Marum RJv, Schut GL, Ribbe MW, Meijer JH. Pathophysiologie en klimische kenmerken van decubitus. (Pathophysiology and clinical characteristics of decubitus). Nederlands Tijdschrift voor Geneeskunde 241 1994:138(2):66-71.

57. Tappan F. Healing Massage Techniques. Holistic, classic, and Emerging Methods. California: Appleton \& Lange; 1988.

58. Goats GC. Massage - the scientific basis of an ancient art: Part 2. Br J Sports Med 1994;28:153-6.

59. Mustoe T. Understanding chronic wounds: a unifying hypothesis on their pathogenesis and implications for therapy. American Joumal of Surgery 2004:187(5A):565-70.

60.Lishmer M, Lang R, Kedar I, Ravid M. Treatment of diabetic perforating ulcers (mal perforant) with local dimethyl sulfoxide. I Am Geriatr Soc $1985,33: 41-3$.

61. Kedar I, Jacob E, Ravid M. Dimethylsulfoxide in acute ischaemia of the kidney: Experimental models in the rat and in the dog. Ann NY Acad Scl $1983 ; 411: 131$.

62. Van Ros5um JP. Behandeling en preventie van decubitus met dimethyl sulfoxide - verslag van een pilotstudie. (Treatment and prevention of pressure sores with Dimethyl Sulfoxide - report on a pilot-study). In: 1997. 
63. Bours GJJW. Halfens RJG, Joosten CMC Landelijk prevalentie onder zoek decubitus: uitgebreide resultaten tweede jaarlijkse mething 1999. (Annual Dutch Prevalence Pressure Ulcer Survey: results of the second annual survey (1999)) $2 e$ herziene $d r$. Maastricht.: Universiteit Maastricht, Dep. Health Care Studies / Section Nursing Science, Máastricht.

64. Huisenboom MA. Decubituspreventie door de jaren heen. Een vergelijking van de kennis en inzet van preventieve maatregelen bij decubitus door verpleegkundigen en verzorgenden. (Prevention of pressure ulcers. A comparison of the knowledge and use of methods to prevent pressure ulcers by nurses and health care givers][Master-Thesis]. Maastricht: Universiteit Maastricht: 2004. 


\section{chapter 2}

\section{The effects of massage as a method to prevent pressure ulcers. A review of the literature.}

Inge GP Duimel-Peeters, Ruud JG Halfens, Martijn PF Berger, Luc HEH Snoeckx

Based on paper published in:

Ostomy/Wound Management 2005;51(4):70-80.

General information about the effects of massage to prevent pressure ulcers is ij mited. A literature search was conducted to provide more detalled knowledge about the effects of massage in general and in preventing the development of prossure ulcers in particular. Using the keywords massage, rubbing, prevention of pressure ulcers/pressure sores, and paying particular attention to referenced articles yielded a summary of different manual massage techniques and indications/contra-indications of this intervention for both heatthy tissues and tissues in patients at risk for developing pressure ulcers. A careful review of this information; the clinical, physical, and pathophysiological aspects of pressure ulcers, including extrinsic and intrinsic factors: and the time-pressure relationship suggests that one type of massage may be beneficial for persons who are at risk for developing pressure ulcers, although based on currently existing studies, it cannot be proven statistically that massage is an adequate preventive method for pressure ulcers. Although many guidelines advise against the use of massage in people at risk for pressure ulcers. current evidence suggests that research to increase knowledge about the mechanism behind the effects of massage as a part of an individual prevention and treatument plan should be conducted. 
ouch is a natural human response to alleviate pain in the skin or under-
lying tissue. Physical contact, particularly irvolving hands, can be an essential component of the healing process." The art of massage was developed long ago based on this knowledge; references to massage can be found in writings earlier than $2000 \mathrm{BC},{ }^{(23)}$

Although a considerable amount of information is available on the mechanical, physiological, and relaxing effects of massage, as well as on its indications and contraindications, little is known about its ability to prevent the development of pressure ulcers (PU). Some physiological and therapeutic effects of massage are still questioned ${ }^{(4)}$; moreover, the potential for massage to prevent PUS is widely criticized. Some authors believe it actually causes the development of pressure ulcers. (3)

A literature review was conducted to address existing contradictory opinions about the effects of massage and to provide erhanced insight into the role of massage in the PU development, especially among elderly. This article summarizes the state of the art regarding the effects of different massage techniques, identifies the most important general indications and contraindications for massage, and offers applications for practice in patients prone to developing pressure ulcers. The reviewed literature was obtained through a search of Medline and Pubmed using the keywords pressure ulcer (PU), massage, rubbing prevention of PU, and by examining the references of all retrieved articles. Conclusions about the effectiveness of massage in preventing PUs are presented following a short description of the aetiology and the pathophysiology of PUS and existing information about the mechanical and physiological effects of massage.

\section{Different massage tecúniques}

Manual massage techniques are divided in two general categories Swedish and Chinese (the latter is discussed elsewhere). (2) Swedish massage is applied on muscle, tendons and soft tissue. French terminology is used to differentiate between stroke types. 
Effleurage (a stroke that glides). Effleurage consists of slow, thythmic stroking hand movements moulded to the shape of the skin and is frequently used to start and finish a treatment session. The strokes pass from dism tall to proximal and parallel the long axis of the tissue. Firm pressure is believed to accelerate blood and lymph flow, to improve tissue drainage and, as such: to reduce swelling, , 5 .9) $^{2}$

Petrissage (a stroke that kneads). Petrissage or skin rolling is a forceful technique that can only be applied to fleshy regions of the body. A fold of skin, subcutaneous tissue, or muscle is squeezed, lifted, and rolled in a continuous circular motion against the underlying tissues. ly useful for stretching contracted or adherent fibrous tissue and to relieve muscle spasm.

Tapotement (striking). Tapotement is the general name given to percussive massage techniques. Vigorous tapping vibrates tissues and triggers cutaneous reflexes such as vasodilatation.(5.3) Vasodilatation, in turm, increases muscle tone and promotes interstitial fluid circulation, reduces swelling, and accelerates healing processes, ${ }^{(6,7,70)}$

Friction (compression). Friction is an accurately delivered penetrating pressure applied in small areas with the fingertips. It is especially effective for the treatment of adherent or contracted connective tissue ${ }^{(5,6)}$; therefore, it is specifically recommended in sports therapy.

Vibrations (shaking or vibrating). Vibrations are delivered by trembling both hands held firmly in contact with the skin. Unlike effleurage, this method compresses swollen tissue and can reduce edema with less risk of spreading infection. ${ }^{(5)}$ This technique is mostly used in respiratory physiotherapy.

\section{I When is massage generally indicated or contra-indicated?}

Nurses and other health care givers using manual massage need to know whether massage is appropriate. In healthy tissues, massage is known to have the following advantageous effects: encouraging hyperaemia as a consequence of histamine release, increasing tissue suppleness, relaxing muscle tone, increasing parasympathetic activity, reducing edema, relieving subcutaneous scar tissue, and activating mast cells. ${ }^{(27.9 n i n}$ However, massage is con- 
tra-indicated when tissues are inflamed or when the risk for malignant cells to spread along the skin or through the lymph or the blood stream (ymphangitis, malignant melanoma) is increased. Massage is also contra-indicated when patients are prone to bleieding (ecchymosis), have disorders of the cir culatory system (phebitis, severe atherosclerosis), and have abnormal semsations due to stroke, diabetes, and medication. Long-term massage is also known to cause desquamation (the skin peels or comes off in scales) described by the European Pressure Ulcer Advisory Panel (EPUAP) guidelines as grade 2 of pressure ullcers. (1*) $^{(4)}$

Opinion is divided on the use of massage in patients prone to pressure ulcers. Some authors are convinced that massage prevents the bedridden patient from developing pressure ulcers, particularly if the patient is unable to move. However, when such patients show signs of acute tissue inflammation, massage treatment can be counterproductive. As such, recognizing early signs of inflammation is important and increasing numbers of clinicians agree that pressure ulcers are related to a form of chronic inflammation. ${ }^{\text {(56-17) }}$

The literature indicates that effleurage was the preferred technique in the treatment of pressure ulcers and should be applied with moderate pressure because unnecessarily high pressures are harmful to underlying tisswes, na zion

Other massage techniques such as tapotement and friction are rather painful, making them dusadvantageous for use in the thin, elderly patients. Aso, because friction can easily cause mild tissue destruction or provoke an infiammatory reaction, it is contra-indicated for people who are not in good healthus

\section{I clinical and physical aspects of pressure ulcers}

With the average age of the population on the increase and improved medical care prolonging life, the medical profession is faced with the increasing problem of caring for the elderly and people with disabilities. Pressure ulcers are a common problem in this population, developing locally where soft tissue is compressed between a bony prominence and a firm surface for a prolonged period. "16.7) Pressure ulcers occur in superficial as well as deeper layers of the skin or even in the underlying muscles. The EPUAP classification system is 
the most commonly used international grading system to determine the grade of a PU (Table 1). (19)

\section{Table 11 Grading System of Pressure Ulcers}

Grade Description

I Non-blanchable discoloration of intact skin;

II Partial-thickness skin loss involving epidermis, and/or blister or shallow ulcer without undermining of adjacent tissue;

III Full-thickness skin loss involving damage or necrosis of the epidermis andlor dermis not extending to underlying bone, tendon or joint;

IV Full-thickness skin loss involving damage or necrosis of the epidermis and/or dermis extending to underlying bone, tendon or joint.

\subsection{I prysiology of the skin}

The skin constitutes the outer boundary of the human body and functions both as a barrier and as a connection between the outer world and the internal organs.(15) The skin accounts for $16 \%$ of the body's total weight and has a total surface area of 1.2 to $2.3 \mathrm{~m}^{2}$ in an adult person. (2123) The largest organ in the body, the skin fulfils many essential tasks (see Table 2). Clearly, these functions can be threatened when the skin is damaged by a PU.

Table 2 I The Functions of the Skin

- Maintenance of body temperature through vasodilatation and constriction of the surface blood vessels

- Protection from friction and shear, dehydration, ultraviolet light and radiation

- Perception of temperature and pain

- Perception of pressure, touch and vibration (collectively: tactile sensations)

- Excretion of small amounts of salts and perspiration (aids thermal regulation)

- Vitamin D synthesis

- Preventing loss of water and electrolytes 


\subsection{Extrinsic factors involved in the development of pressure vilcers}

The risk of PUs can be provoked by extrinsic and intrinsic factors. The three extrinsic factors related to PU development are pressure on and shear and friction within the tissue. ${ }^{(2427)}$ Intrinsic factors include poor blood supply that causes ischemia, reperfusion injury, and inflammation in the affected tissue.

Pressure is created when soft body tissue is compressed between a hard surface and a bony prominence. If this pressure is higher than the capillary pressure, local blood flow is reduced and ischemia may result. (16.25) The location of the onset of pressure ulcers is irifluenced by the nature of the external loading. Pressures applied perpendicularly on the skin above a bony prominence, simultaneously compress a small part of subcutaneous fat and muscle tissue above that prominence, potentially causing extensive damage that commences from locations deep within the muscle tissue layer without visible signs at the skin surface. ${ }^{299}$ This effect will be strengthened because the skin is mechanically stronger than underlying tissues and is better equipped to survive periods of ischemia. ${ }^{(30)}$ In contrast, superficial pressure ulcers are mainly caused by shearing forces and initiate in the skin with maceration and detachment of the superficial skin layers. ${ }^{(3)}$ In addition, deep ulcers develop at a faster rate than superficial ulcers, making them even more harmful. (i)

Local tissue shear forces are typically problematic when a patient is sitting (chair or wheelchair) for several hours. Shearing forces destroy the microcimculation by causing thrombosis of the vessels.(32) Preventing the patient from sitting in a tangential way - the position in which most often shear farces occur - is important

Friction is a periodic change in shear and occurs when one surface is moving rhythmically over another, such as when the patient is semidependent and semirecumbent, and is inadequately/infrequently lifted from a bed. Friction can cause stripping of the skin, leading to superficial ulceration.

A preventive strategy developed to address extrinsic factors provoking pressure ulcers should be based on avoidance or reduction of shearing and friction forces andior relief of excessive local pressure at all body-support interfaces.(3) However, individual susceptibility to pressure ulcers can vary 
substantially and affect any measure taken to reduce pressure, shear, or friction. ${ }^{(35)}$

\subsection{Intrinsic factors involved in the development of pressure ulcers}

\section{A. Blood supply to skin and muscle}

Interruption of the normal blood supply to skin and muscle by increased localized pressure can result in tissue ischemia and hypoxia when the resultant pressure is greater than capillary pressure and persists over a critical time period. ${ }^{[27)}$ Eventually, this can lead to tissue necrosis. Furthermore, when pressure on an ischemic area is relieved, a red area appears on the skin over the bony prominence due to a reactive hyperaemia. This phenomenon is typical for tissue that is still viable and characterizes the normal response after temporal flow reduction. In contrast, when the red area does not blanch when light finger pressure is applied, this is termed non-reactive hyperaemia. This event is a typical precursor to the development of pressure ulcers. ${ }^{[2])}$ The same type of tissue breakdown or necrosis results from pressure-induced muscle ischemia in bedridden patients. Continuous compression interrupts blood and lymph flow and deprives the tissue of access to oxygen and nutrients, and toxic waste product removal. Individual cells produce toxic metabolites that cause tissue acidosis, increased capillary permeability, edema, and eventually necrotic cell death. (17.27) Pressure ulcerations are lacalized areas of cellular necrosis. Where normal cell metabolism is dependent on the receipt of nutrients and the elimination of metabolites, compression will interfere with this exchange. Because muscle tissue has a lower tolerance to local ischemia than the skin, tissue necrosis conceivably could occur earlier in compressed muscle than in the skin. ${ }^{(n)}$

\section{B. Reperfusion injury}

In compressed tissue, blood flow can be restored intermittently, suddenly reperfusing the tissues with oxygenated blood. Paradoxically, this phenomenon can also be harmful, causing occlusion-reperfusion injury. ${ }^{(36)}$ Due to the sudden increase in oxygenation and the ischemia-induced suppression of enzyme activity, oxygen-related free radicals can damage cell membranes and initiate the process of cell necrosis. 


\section{Inflammation}

Prolonged ischemia and reperfusion injury both cause serious tissue damage, leading to cell necrosis that, in turn, will initiate an inflammatory response characterized by vasodilatation leading to redness of skin and increased temperature. Furthermore, the tissue swells due to increased permeability of blood vessels. This process is associated with pain, probably caused by tissue distortion and production of chemical mediators. Eventually the various events can cause thrombosis in the capillaries.

4.4 I Time-pressure relationship and the interstitial finid compartments

Extensive research in experimental animals and humans has shown that the development of pressure ulcers depends on the pressure level and the duration of the pressure on the tissue (see Figure 1), and the direction of pressure. 30 ?

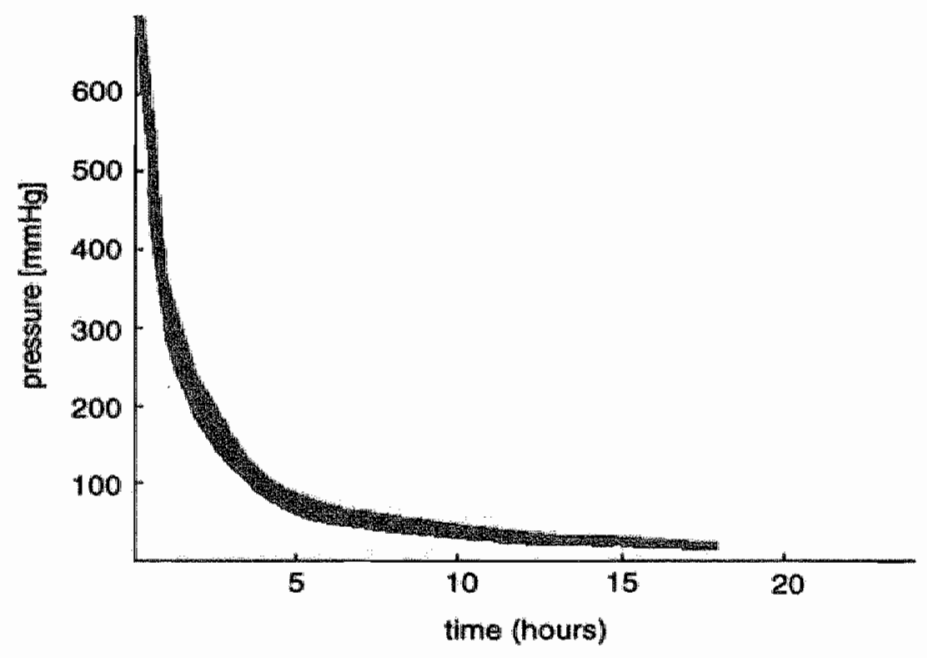

Figure 1 I Pressure ulcer risk curve. Pressure/time combiration above the curve will lead to tiswue breakdown. (2ura)

Increasing the surface of the body in contact with the bottorn tissue layer can reduce the intensity of pressure. 
the length of time seems to create an inverse relationship between tissue damage and external load magnitude and duration. ${ }^{20,23)}$ ? Thus, a large- load magnitude applied during a short time and smaller loads applied for prolonged times result in tissue damage. ${ }^{(1625-50)}$ An explanation for this timepressure relationship is not immediately at hand. Stagnation of blood flow cannot be the only reason for damage; otherwise, every pressure high enough to cut off a vein would lead to pressure ulcer development. A possible explamation could be that pressure and shear lead to a local pressure increase in the interstitial fluid between the cells. Consequently, the fluid will stream slowly away to areas with lower pressure. In these areas, cells will experience a higher pressure, resulting in breakdown through mechanical overloading.

\section{I Discussion: the use of massage to prevent pressure ulcers}

Massage on healthy tissues supports adequate tissue blood perfusion; encourages lymphatic drainage, thereby reducing edema; provides gentle stretching of tissue; and relieves subcutaneous scar tissue. (2-4.6.37.41) This suggests that massage, and especially effleurages, is effective in the prevention of pressure ulcers because tissue drainage is improved, swelling is reduced and vascularization is normalized. However, when massage is applied on tissues prone to the development of pressure ulcers, it can have a deleterious effect, provoking further cell damage through the excessive formation of oxygen free radicals as a consequence of hyperaemia. ${ }^{(30)}$ Nevertheless, this negative effect can be balanced through the restoration of necessary blood flow. Cellular metabolic homeostasis is better preserved and toxic metabolites are better removed through improved blood circulation (see figure 2). Studies conducted on the effects of massage on skin, immunity, blood flow, and pressure ulcers are summarized in Table 3. 
5.11 Arguments in favor of massage as a preventive method in the Pu development

In a review of mechanical methods of preventing pressure ulcers in elderly patients, Bliss ${ }^{(32)}$ claims that purposeful effleurages over threatened areas once or twice daily were effective in preventing the development of pressure ulcers. The additional consequence of rubbing the patient twice daily is a change of position and pressure relief on the compressed areas twice a day. The change of position can cause effect-modification. However, the author of this study did not mention how a possible source of bias was addressed. Célice ${ }^{(n 2)}$ describes positive effects of robust massage for 15 minutes to prevent pressure ulcers in bedridden patients. At the end of each massage session, a slight bloodstained pink color appeared at the treated body part, indicative of hyperaemia. Besides this visual observation, the results of this study lack statistically scientific evidence. A pilot-study performed by van den Bunt ${ }^{\{43\}}$ shows a positive effect of massage on the prevention of pressure ulcers. The author claims that rubbing the patient prevents the development of PUs but did not mention how. This finding is not supported by any scientific argument; furthermore, the type of massage used is not clear. Although the study found that massage has positive effects, it does not provide more scientific information - specific definitions of "rubbing", "regularly", "massage" and "positive effects" were absent.

Iwama(i) and Ironson ${ }^{(9)}$ investigated the effect of massage on the immune system by collecting blood before, during, and after completion of massage. They found that massage had a stimulatory effect on the sympathetic nerves (relaxation) and activated and increased the number of natural killer cells. They concluded that massage prevents the occurrence of PUs through the reactivation of the depressed immune system, as observed in elderly bedridden patients. They are convinced that skin rubdown (i.e., robust massage) should be recognised as a simple health procedure that improves cellular immunity. Corley ${ }^{(39)}$ notes that several physiological measures, such as heart rate and blood pressure, did not change significantly after back rub massage; however, the group of patients studied showed a significant 
increase in 5 kin temperature. More than half of the persons treated said they felt more relaxed and relieved of pain after the massage. In addition, patients. experienced a significantly positive change in mood in comparison with the control group, which for instance, resulted in a better night's rest.

\subsection{Arguments against massage as a preventive method in the PH develop-} ment

Opponents of massage as a method to prevent the development of pressure ulcers claim it has no effect or inflicts more harm than benefits. The outcome of Ek's study"? show that massage on normal skin had an inconsistent and non-significant effect on blood flow as measured by laser Doppler flowmetry. Furthermore, patients with skin discoloration reacted with a reduced blood flow after the massage was implemented. Frant $z^{(40)}$ found the same inconsistencies when looking at the single effects of prolonged pressure on skin blood flow over the trochanters of 16 elderly patients at risk for pressure ulcers. Blood flow tracings in the skin during a 60 -minute period of continuous pressure revealed an inconsistent pattern of response; the flow increased, decreased or showed no change. Although this study involved a relatively small number of patients undergoing pressure for a single 1-hour session, results implied that additional studies with larger populations over longer periods of time are warranted. Braden ${ }^{(19)}$ states that massage to prevent pressure ulcers is no longer considered appropriate skin care and is even harmful if ischemic injury is already present. Massaging a non-blanchable skin discoloration to prevent further damage is pointless because the blood ves. sels already are dilated; thus, massage may force toxic substances to leak into the interstitial space, which, in turn, may cause tissue damage. Olson ${ }^{201}$ also does not recommend extensive massage to a formerly compressed area because circulation would be further compromised; however, the small sample size, lack of a control group (i.e., group without massage), and the participation of a unique population (patients with fractured hips) limits the generalization of the results. Meaume ${ }^{(4)}$ states no confirmed reports of efficacy support the widespread usage of massage in France and further argues that rubbing pressure ulcers, especially grade I ulcers, should be contra-indicated 
because underlying tissues are damaged by decreased blood flow and, consequently, elevated skin temperature. Dyson ${ }^{[8]}$ studied the effects of massage on geriatric patients over a 6 -month period and found the incidence of pressure ulcers was greatly reduced if patients were not rubbed at all; on postmortem examination, massaged areas exhibited macerated and degenerated tissue, while unmassaged tissue remained healthy with no signs of tearing. The author did not stipulate the massage technique used-only the term vigorous is mentioned. However, in the past massage meant strong rub and pinch - this is not the way effleurages are performed today. Dyson's findings are interesting but lack scientific documentation on the methods and conditions of the research.

The questionable usefulness of petrissage, tapotement, friction and vibration in the treatment of elderly patients prone to pressure ulcers has met with considerable agreement. $(5 \%, 0,1,20,38,44)$

Petrissage (skin rolling) is a forceful technique. Because of its effects and means of application, it is completely contra-indicated in the prevention and treatment of pressure ulcers. Petrissage is harmful to underlying tissues, especially when they are in a compromised condition. Meaume ${ }^{(4+4)}$ reports that this technique has been abandoned in France and replaced by effleurage. Hovind and Nielsen ${ }^{(38)}$ conclude that petrissage has a variable and inconsistent effect on blood flow but that hyperaemia is absent.

Physlologically, tapotement provides an immediate increase in blood flow during the treatment, reaching values $35 \%$ higher than normal. ${ }^{336}$ However, because it is rather painful, the technique is deleterious, especially in thin, elderly patients. The same may be said for friction, which can be painful and stimulates a marked local hyperaemia or an inflammatory reaction. (25) Vibrations are also not recommended in the prevention of PUS because of the extended and robust way of performing this type of massage. Several authors have suggested that vigorous massage over bony prominences should be avoided because it provokes muscle damage not visually apparent. 
Pressure + time

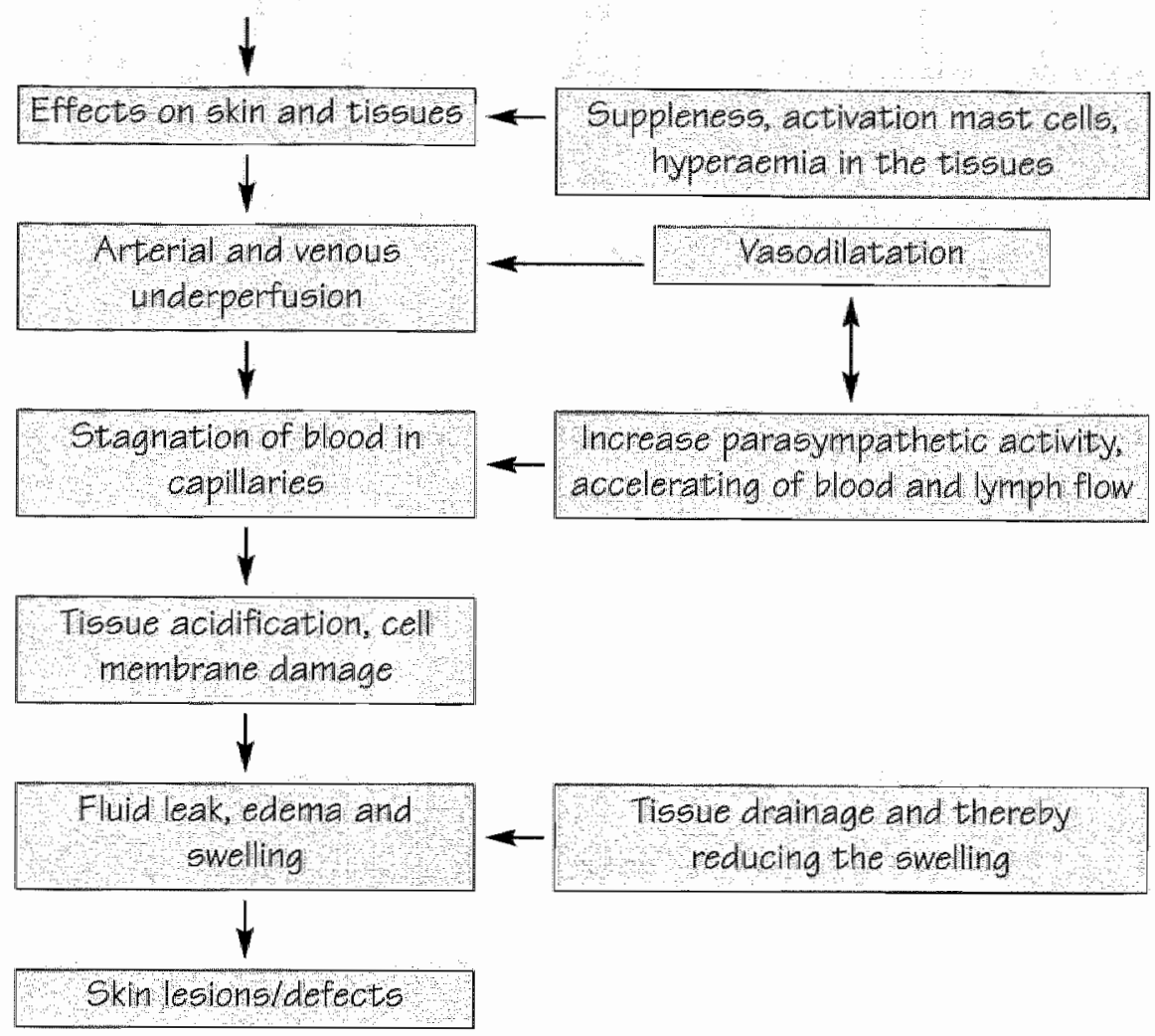

Effects of massage

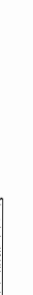


injured skin. Although healthcare workers often believe in the preventive effect of massage ${ }^{i t 57}$, no clear scientific evidence has yet been presented in terms of the beneficial effects of massage in the prevention of pressure ulcers, particularly among the elderly and people at risk.

However, because of the relatively small number of participants and questionable methodological quality of the studies, contra-indications may, in some cases, be worthy of the benefit of the doubt. Massage (i.e, effleurages) may be beneficial in some instances after careful consideration of the patient's physical condition and medical history and respecting individual variability in administering massages. The mechanism behind the effects of massage is still an important field for research. 


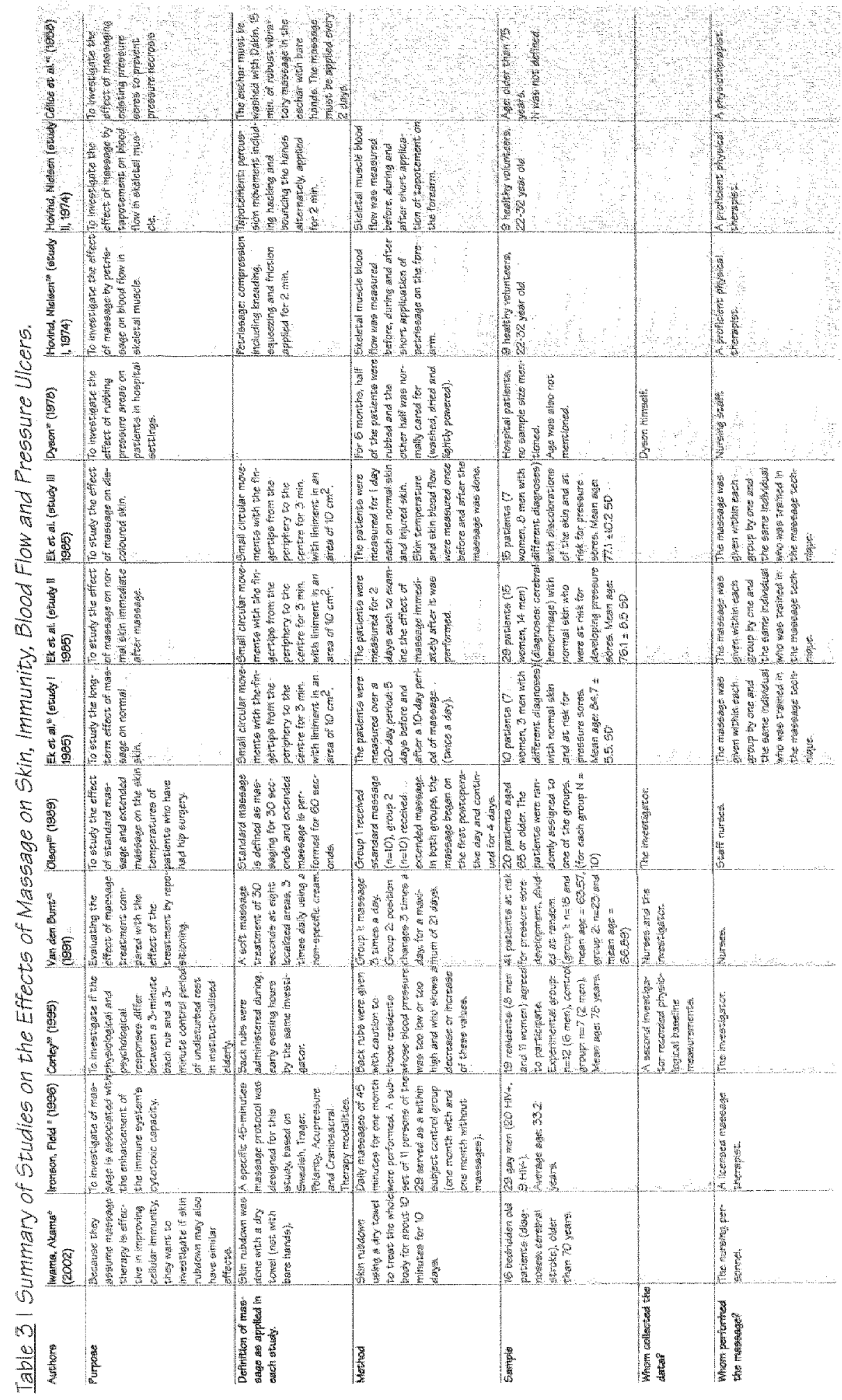




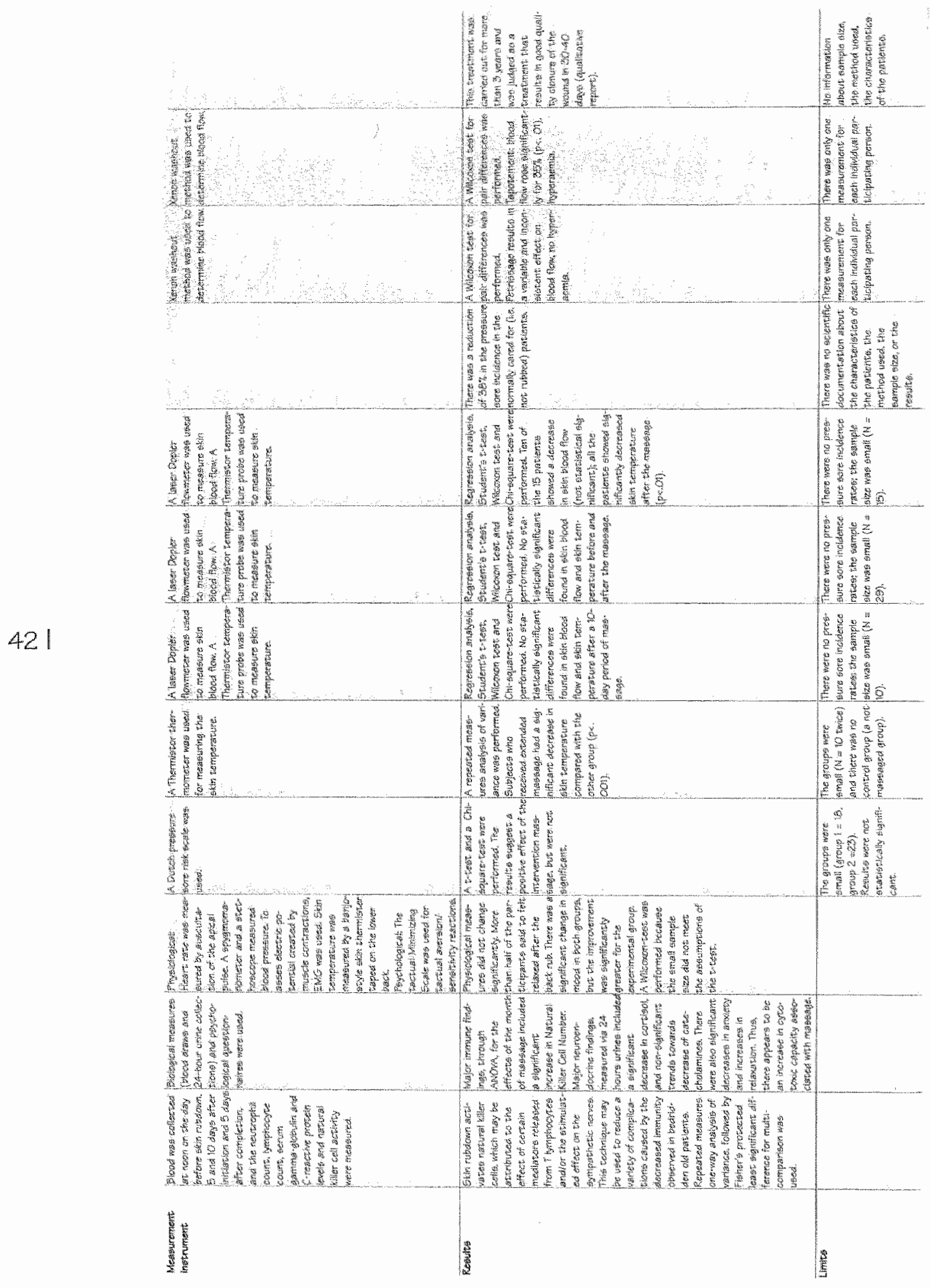


1. Murphy C. Massage - A Perspective. Physiotherapy 1996;82(10):555-6.

2. Tappan F. Healing Massage Techniques. Holistic, classic, and Energing Methods. Califormia: Appleton \& Lange; 1988.

3. Buss IC, Halfens, RJG, Abu-Saad, HH. The effectiviness of massage in preventing pressure sores: a literature review. Rehablitation Nursing $1997: 22(5): 229-34$

4. Goats GC. Massage-the scientific basis of an anclent art: Part 2. British Journal of Sports Medicine 1994;28:153-6.

5. Goats GC. Massage-the scientific basis of an ancient art: Part 1. The techniques. British Journal of Sports Medicine 1994:28:149-52.

6. Wakim KG. Physiologic Effects of Massage. In: Licht S, editor. Massage, manipulation and traction. New York: Robert E. Krieger Publishing company: 1976 . p. 38-43.

7. Huber E. Wann ist eine Massage indiziert? (When is it indicated to use massage?). Zeitschirft für Allgemeinmedizin 1981;57:1485-93.

8. I wama H. Akama, Y. Skin rubdown with a dry towel activates natural killer cells in bedridden old patients. Medical Science Monitor 2002;8(9):611-15.

9. Ironson G. Field, T. Massage therapy is associated with enthancement of the irmune system's cytotoxic capacity. International Journal of Neuroscience 1996;84:205-17.

10. AMTA. In: American Massage Therapy Association. Available at wwwamtamassage.org.

11. Justin-Besançon L, Péquignot, H., Etienne, J.P., Savier, J., Vilain, R. Les Escarres dites de décubitus pathogénie, prophylaxie et traitement (The prevention of bedsores in general medicine). La semaine des Hôpitaux de Paris 1957:33:4115-21.

12. EK AC, Gustavsson G, Lewis DH. The local skin blood flow in areas at risk for pressure sores treated with massage. Scandinavian Journal of Rehabilitation Medicine 1985;17(2):81 6 .

13. Cherkin D, Sherman, K., Deyo, R., Shekelle, P. A. Review of the Evidence for the Effectiviness, Safety, and Cost of Acupuncture, Massage thera. 
py, and Spinal Manipulation for Back Pain. Arnals of Internal Medicine 2003:138.898-906.

14. European Pressure Ulcer Advisory Panel (EPUAP). Education : experiences we can share [5th EPLAP open meeting]. In: 5th European Pressure Ulcer Advisory Panel open meeting; 2001 September 27-29, 2001: Le Mans, France.

15. Hartmann P. Compendium Wounds and Wound Management. Heidenheim: Paul Hartmann AG; 2003.

16. Kosiak M. Etiology of Decubitus Ulcers. Archives of Physical Medicine and Rehabiliation 1961;1:19-29.

17. Maklebust J. Pressure Ulcers: etiology and Prevention. Nursing Clinics of North America 1987;22:359-77.

18. Dyson R. Bed sores: the injuries hospital staff inflict on patients. Nursing Mirror 1978;146(24):30-2.

19. Braden Bu, Bryant R. Inmovations to prevent and treat pressure ulcers. Geriatric Nursing 1990:182-6.

$441 \quad 20$. Olson B. Effects of massage for prevention of pressure ulcers. Decubitus $1989 ; 2(4): 32-7$

21. Despopoulos A, Silbernagl, S. Color Atlas of Physiology. New York: Thieme Medical Publishers; 1991.

22. Junqueira LC, Carneiro, J., Kelley, R.O. Functionele Histologie (Basic Histology). Maarssen: Elsevier/Bunge; 1998.

23. Asmussen P, Söllner, B. De huid. Meer dan een handig Jasje. (The skin is more than a convenient jacket). Nursing96:1996:60-3.

24. Keuzenkamp T. De conservatieve behandeling van decubitus. (The conservative treatment of pressure sores). Utrecht/Antwerpen: Bohn. Scheltema \& Holkema; 1982.

25. Horsley JA, Crane J, Haller KB, Bingle JD, editors. Preventing decubitus ulcers: CURN project. New York etc.: Grune \& Stratton; 1981.

26. Reuler JB, Cooney TG. The pressure ulcer: pathophysiology and principles of management. Annals of Internal Medicine 1981:94(5):661-6.

27. Russell L. Physiology of the skin and prevention of pressure sores. British Journal of Sports Medicine 1998;7:1084-1100. 
28. Goossens RHM. Klinisch fysische aspecten van decubitus. (The clinical and physical aspects of pressure ulcers). Klinsche Fysica 1995;1995(3):21-4.

29. Breuls R. Experimental and theoretical analyses of compression induced muscle damage. Eindhoven: Technische Universiteit Eindhoven; 2003 (PhD-Thesis).

30. Marum RJv, Schut GL, Ribbe MW, Meijer JH. Pathophysiologie en klinische kenmerken van decubitus. (Pathophysiology and clinical characteristics of decubitus). Nederlands Tijdschrift woor Geneeskunde 1994:138(2):66-71.

31. Bosboom M. Deformation as a trigger for pressure sore related muscle damage. Eindhoven: Technische Universiteit Eindhoven: 2001 (PhDThesis).

32. Bliss MR. A consideration of mechanical methods of preventing bed ulcers in elderly patients. Gerontology Clinic. 1964;6:10-21.

33. Pootjes YG. Ribbe MH, Schneider H. Preventie van decubitus: een overzicht. (Prevention of decubitus : an overview). Tijdschrift voor Gerontologie en Geriatrie 1986;17(4):141-6.

34.Cherry GW, Ryan TJ. Pathophysiology. In: Parish LC. Witkowski JA, Crissey JT, editors. The decubitus ulcer. New York: Masson Pub. USA; 1983. p. 134.

35. Meijer JH, Germs PH, Schmeider H, Ribbe MW. Susceptibility to decubltus ulcer formation. Archives of Physical and Medical Rehabilltation 1994:9:36-40.

36. Houwing RH, Overgoor M. Pressure-induced skin lesions in pigs: reperfusion injury and the effects of vitamin E. Journal of Wound Care 2000;9:36-40.

37. Buss IC, Halfens, RJG. Richtlijnen woor decubitus zijn te weinig bekend. Massage helpt niet. (Guidelines for pressure ulcer prevention are not well known. Massage does not help.). Tijdschrift voor Verpleegkundigen 1997;107:346-8.

38. Hovind H. Nielsen SL. Effect of massage on blood flow in skeletal muscle. Scandinavian Journal of Rehabilitation Medicine 1974;6(2):74-7. 
39. Corley MC, Ferriter J, Zeh J, Gifford C. Physiological and psychological effects of back rubs. Applied Nursing Research 1995;8(1):39-43.

4O. Frantz RA, Xakellis GC. Arteaga M. The effects of prolonged pressure on skin blood flow in elderly patients at risk for pressure ulcers. Decubitus 1993;6(6):16-20.

41. Anthony $D$. The treatment of decubitus ulcers: a century of misinformation in the textbook5. Journal of Advanced Nursing 1996;24(2):309-16.

42. Célice J. Fierabras E, Chappon G. Duroux P. Traitement des escarres de décubitus des grabataires par les massages in situ. (Treatment of pressure ulcers in the bedridden by massage in situ). Thérapie 1958:13:898-900.

43. Bunt CEvd. De effektiviteit van wrijven als interventie om decubitus te voorkomen. (The effectiviness of massage as a preventive method for pressure uicers.) [Annual Paper]. Maastricht: Universiteit Maastricht; 1991.

44. Meaume S, Senet P. Prévention des escarres chez la personne âgée: escarres de décubitus en médecine gériatrique. (Prevention of decubitus scars in the elderly.). La Presse Médicale 1999;28(33):1846-53.

45. Halfens RJG. Eggink M. Knowledge, beliefs and use of nursing methads in preventing pressure sores in Dutch hospitals. International Journal of Nursing Studies 1995:32(1):16-26. 


\section{Chapter 3}

\section{A systematic review of the efficacy of topical skin application of Dimethyl Sulfoxide on wound healing and as an anti-inflammatory drug.}

Inge GP Duimel-Peeters, Ronald H Houwing, Coen P Teunissen, Martijn PF Berger, Luc HEH Snoeckx, Ruud JG Halfens.

Based on paper published in: Wounds 2003;15(11):361-370.

Background: Preceding our research about the evaluation of massage with a cream that contains dimethyl sulfoxide (DMSO) as a preventive method for pressure ulcers, a riview study was completed. Articles on application of DMSO on the human skirn in conditions where wound healing andror inflammation characteristics are involved were included. Objectives: The literature was evaluated with respect to the efficacy of DMSO in different concentrations on wound healing and as an anti-inflammatory drug. administered by topical application to the skin. Methods: This systematic review was performed according to the rules of the meta-analysis. The authors searched for articles in MEDLINE, PUBMED. EMBASE-Excerpta Medica, the Cochrane Controlled Trial Register and Database for Clinical Reviews, and the Cochrane Skin and Wounds Group. Conclusions were made after blinded assessment of the methodological quality of the studies according to the standardized methodological criteria. Disagreements between reviewers were identified and subsequentIy discussed. If disagreements were not resolved, a fourth, blinded, expert reviewer would be consulted. Results and Conclusions: A review of the literature on experimental dermatological studies using DMSO revealed numerous studies using experimental animals. Dermatological studies with DwSO in humans have been scarce. Athough the included studies were based on small samples and often lacked reference groups, the authors concluded that DMSO seems safe to use in concentrations less than 50 percent, either by rubbing or by spraying; DMSO in concentrations higher than 50 percent gives an increasing risk of side effects; and at concentrations below 50 percent. DMSO has favorable effects on inflammation and wound healing. as well as an analgesic effect. 
$P$ ressure ulcers, also commonly referred to as bedsores, pressure sores, decubitus ulcers or simply decubitus, can develop when sustained load, friction or shear is applied to localized areas of the body, leading to degeneration of the skin and underlying soft tissues. As in other countries, pressure ulcers form a major problem in Dutch institutions for health care services." Various theories have been forwarded to explain the aetiology of pressure ulcers, with most experts adhering to the theory that pressure ulcers result. from chronic acclusion of capilary blood flow, leading to alternating periods of ischemia and reperfusion. This process is associated with repetitive formation of reactive oxygen species (ROS) and concomitant tissue necrosis. Recently, pilot studies have revealed that rubbing the intact skin with a dimethyl sulfoxide (DMSO)-containing cream during the first stage of pressure ulcers according to the four grade system of the European Pressure Ulcer Advisory Panel (EPLAP), leads to a decrease in pressure ulcer occurrence among high risk patients.

DMSO $\left(\left(\mathrm{CH}_{3}\right)_{2} \mathrm{S-O}\right)$ is a water-white to straw-yellow-colored organic liquid. It is an oily substance with a smell of sulfur and a slightly bitter taste. In topical application, this simple, highly polar chemical compound has been found to alleviate ischemic damage in several experimental animal models. ${ }^{(5,6)}$ In addition to an analgesic effect, the most important property of DMSO is the enhancememt of percutaneous penetration. ${ }^{(7)}$ When used in combination with other substances, DMSO facilitates their diffusion through the stratum corneum of the skin, triggers the formation of deposits in the deeper layers of the subcutaneous tissue and promotes transport into the local blood vessels. Hence, dermatologists use it as a vehicle for other medication.

In pressure ulcer tissue, like any tissue in which inflammation occurs, repetitive ischemia-reperfusion episodes lead to the local formation of ROS. The main representatives of these radicals are the superoxide anion $\left(\mathrm{O}_{2}-\right.$ ), hydrogen peroxide $\left(\mathrm{H}_{2} \mathrm{O}_{2}\right)$ and the hydroxyl radical $\left(\mathrm{OH}^{-}\right)$. Since DMSO is known to be a hydroxyl-inactivating compound, it can be assumed that its beneficial effects on pressure ulcers are based upon this activity.

The purpose of this review is to evaluate the literature on the efficacy of 
DMSO in various concentrations on wound healing and as an anti-inflammatory drug, administered by topical application to the skin.

\section{Methods}

A MEDLINE literature research was carried out covering the last 36 years (starting in 1966). At first, the search was determined on studies involving DMSO by one specific disorder, eng., pressure ulcers. However, this dild not yield enough articles, so the "domain' had to be expended. The following keywords were used: dimethyl sulfoxide, clinical dermatology, pharmacology and toxicology, bio-penetrator, the skin, hydroxyl radicals, ROS, 5cavengers, treatment of ulcers, and inflammation. In addition, the references of all articles retrieved were further examined. The same search was done in PUBMED and EMBASE-Excerptra Medica. A last extensive search strategy was used in the Cochrane Library by means of the Cochrane Controlled Trial Register and the Cochrane Database of Clinical Reviews. Finally, the Cochrane Skin Group and the Cochrane Wounds Group were explored. Abstracts were not selected. One unpublished study was selected because of its relevance to the topic of the present review. ${ }^{(4)}$ Studies were only included if DMSO was applied locally on the diseased skin in conditions involving wound healing andior inflammation, or on healthy skin in order to determine its sensitivity to various DMSO-concentrations. Research using experimental animals was excluded.

Table 1 lists the criteria used, which were weighed by three independent reviewers with different backgrounds (dermatology, pharmacy, and physiotherapy and movement sciences). Detalled information about these criteria is presented in Appendix 1. The criteria are not listed according to the generally acceoted principles of intervention research but based upon the more detailed four general dimensions proposed by Feinstein ${ }^{(9)}$. Bouter ${ }^{\text {(16) }}$ and Assendelft et al. ${ }^{(i))}$, to describe the quality of scientific publications. These four dimensions are the external validity, the internal validity, the method of data-presentation and data-analysis, and the good-clinical-practice-dimension (GCP), which cover over 19 methodological criteria (A-S). Each criterion was given a weight, the sum of which determined the quality for each dimemsion. The score on each dimension revealed the value of each article on each of these dimensions. This system reveals both the strong and weak points of each of the presented studies. 
Table 110 imensions of quality table; a criteria list for the methodological assessment of articles about the efficacy of DMSO on wound healing and as an antimitammatory drug, topically applied to the skin.

\section{Dimensions of quality (criteria*)}

Weight Factor

\section{Extermal Vallity}

a. Homogenetty: selection and restriction 3

b. Interventions included in protocol 10 informative described

c. Relevant outcome measures 10

a. Adequate follow-up period 5

e. Description of side effects 2

Internal Valdity

f. Pragmatic study

g. Placebo-controlled study

h. Adequate randomisation procedure /

randomisation concealment

1. Binded assessment of outcome measures 7

j. Comparability of relevant baseline characteristics

k. Drop-outs described for each study group separately

I. Co-interventions avoided

Data (presentation and amalysis)

m. Adequate presentation of data for each study growp

n. 10 subjects in the smallest group 1 $10-20$ subjects in the smallest group 3 20 subjects in the smallest group 5

o. Adustment for confounding variables 5 andior differences at prognostic indicators at, baseline

Good Chical Practice (GCP)

p. Concentrations DMSO described

q. Applicallion DMSO described

f. informed consent of patients

o. Consert of medical ethical conmittee

* A more detailed description of the criterig is given in appendix 1 .

Adapted from Assendelf. WJ.l, Scholten RJPM, van Eijk JTM, Bouter LM. De praktijk van systematische reviews III. Methodologische beoordeling van onderzoeken (The practice of systematic reviews. A methodologlcal assessment of research). Ned Fijdschr Geneeskd $1999 / 43(14): 714-8$
Appendx 11 Details of criteria listed in table 1

\section{External Vallidity}

a. Description of inclusion and exclusion criteria (2 ponts). Restriction to a homogeneous study population (1 point)

b. Marijulative treatment explicity described (5 pointe). All reference treatmerts explicilly described ( 5 points)

c Relevant cutcome measures, which include the following: 1) healing of erythema; 2) healing of ulcers (tattering of the scar, 3) softening of the skin and subcutaneous tissue: 4) analgesic effects/pain relief, 5) less fluid formation; 6 ) increased blood flow, 7) positive effects on ore or more infiammation-gymptoms: rubor, dolor, tumor, calor, 8) histochemical changes (increased fiow of ions); 9) increased range of motion of the affected part of the body (look for biological plausibility between the applied irterventions and the outcome measures)

d. Outcome of measures assessed during or just after the treatment ( 6 points). Outcome of measures assessed after 10 days or longer ( 4 points).

e. Description of side effects (skin imitation, a garitic breath odor, burning or prickling sensation of the skin, blister-formation, urticanial reaction) (2 points).

\section{Internal Valldity}

f. Comparison whth an established treatment (5 points).

o. Companison with placebo (5 points).

h. Randomisation procedure described (2 points). Randomisation procedure that excludes bias; for example, sealed envelopes (= randomisation concealment) (3 points).

1. Each blinded measurement of the first seven measurements mentioned under point $C$ earns 1 point.

j. Comparability for duration of complaints, value of outcome measures (seriousness of complaints), age, recurrences, and sex (1 point each).

k. Information about which group patients withdrew (2 points) from and reason for withdrawal (1 point).

1. Other physical treatments or medical interventions are avoided in the design of the study (medication of no influence on the specific treatment or outcome measurements ( 4 points). If there were other interventions these were identical for all the groups (1 point).

\section{Data (Presentation and Analysis)}

m. Frequencies or means and SD for each study group at intermediate ( 1 point) and final measuremente ( 4 points).

n. Smallest group immediately after randomisation ( $<10=1$ point; $10-20=3$ points; $20=6$ pointsy.

o. Adjustment of results for confounding variables (differences of proginostic characteris tics at baseline) by using multivarite analysis (5 points). This is especially important by nomexperimental research. In case of experimental research, internal validity is guaranteed by the randomisation-procedure. $0 \mathrm{r}$, possible canfounders were considered and were excluded (3 points).

\section{Good Clinical Practice}

p. Description of the used amount of concentration DMSO (2 points).

9. Description of how bMSO is applied to the patient (3 points).

ir. All patients agreed with the informed consent (1 point).

5. There was a consent of the Medical Ethical Committee for the described study (1 point). 


\section{Scoring methods}

All publications were blinded for author(s), joumal and year of publication. The three reviewers independently scored all the criterla listed in Table 1 for each publication, using scores 't,' '“" and '?", with the following meanings:

t: Informative description of each of the above mentioned criteria; adequate study design and implementation (preventing bias).

$\because$ Informative description, but inadequate study design or implementation.

?: Absent or insufficient information, or impossible to assign " + ' or "-".

The level of agreement between the reviewers was determined by calculat ing the inter-rater coefficient Coher's Kappa K. A K-value higher than 0.75 was considered to indicate good agreement, while a value between 0.40 and 0.75 was considered to indicate reasonable agreement. Below $K=0.40$, reviewers were considered to disagree. Upon identification of disagreement, a consensus meeting was organized. If disagreements could not be resolved, a fourth reviewer was to be consulted for a final independent judgment.

All methodological criteria rated " + " were scored using the weighting factors listed in Table 1. The assessments resulted in a hierarchical list for the four dimensions, determining the quality of a particular study/article. Higher scores indicated articles that provided more detailed description of the elements referred to in each criterion, for that specific dimension. Ranking the studies, according to their methodological quality, resulted in two scores; a total score without the goad-clinical-practice-criteria ranging from 4 (poor) to 65 (good), and a second total score including the good-clinical-practicecriteria resulting in scores ranging from 7 (poor) to 71 (good). For the comparison of studies, the authors always applied the second score. An arbitrary cut-off point of 43 was chosen, which is $50 \%$ of the maximum total score when each criterion is totally fulfilled. Below this point studies were defined as of poor methodological quality.

$3 \mid$ Results

The literature search resulted in the identification of 27 publications of which 14 met the inclusion criteria. An overview of the characteristics of 
these studies is given in Table 2. The overall quality of the majority of the studies was rather low (see Table $3^{(12-17)}$ ): only 5 studies received a total score exceeding 43 points (our cut-off point).

The three reviewers initially agreed on 216 of the 266 items ( $81 \%$ ). On the average the inter-rater agreement coefficient Coher's Kappa $K$ between observers 1 and 2 was 0.654 (reasonable), while that between observers 1 and 3 was 0.736 (reasonable) and that between observers 2 and 3 was 0.887 (good). Nearly all disagreements were due to reading errors or to different interpretations of the methodological criteria due to the different backgrounds of the reviewers. Since the three reviewers were able to resolve all disagreements, a fourth reviewer was not consulted.

Most effects of treatment with DMSO reported in these articles were beneficial, both for wound healing and for analgesia. Three of the five studies that scored higher than the cut-off point emphasizes these effects. ${ }^{(182022)}$ The favorable results of DMSO related first of all to its positive anti-inflammatory effects (with a few exceptions), followed by wound healing effects and very often pain relief. In a few cases, DMSO application was associated with the occurrence of more inflammatory signs than with the fact that wounds grew worse. The concentrations of DMSO varied from 5 to 100 percent with only one study expressing a preference for 5 -percent $\mathrm{DMSO}$. $^{(4)}$ A positive correlation was found between the DMSO concentrations and the appearance of side effects. It should be pointed out that at DMSO concentrations below 50 percent (i.e. $10 \%$ or $5 \%$ ), side effects were almost absent, while the positive effects were still obvious!

The criteria upon which patients were selected varied across the studies and were often inadequately described. In a few cases, the sample size was too small to allow reliable conclusions.

The design of the various studies was often inadequate (rated "-) in terms of loss to follow-up, sample size, randomisation procedure, or data-presentation. In 7 articles some kind of information was given regarding dropout rates. The number of patients using DMSO in each of the studies ranged from 2 to 315.

Despite these large differences, some trends could be detected in the outcome measures, the most frequently mentioned being reduction of erythema 
and healing of ulcers, analgesic effects or pain relief, and positive effects on one or more inflammation symptoms such as rubor, dolor, calor and tumor. Negative effects of DMSO always involved deterioration of inflammation signs. The outcome measures are described in detail in Appendix 1. Of the 5 studies ranked highest, 4 studies (Lishner et al., Geertzen et al. Salim et al. . Binnick et al. ${ }^{22}$ ) had high scores for relevant outcome measures. Other studies with only positive results also reached higher methodological scores. Only 5 articles mentioned the use of informed consent and approval by a medical ethics committee.

The ranking of the 14 studies remained unchanged when scores were calculated without the GCP-dimension. Except for the study by Geertzen et al ${ }^{i b y}$, all studies scored relatively better on the external than on the internal validity criteria.

We also computed the inter-item correlations and performed reliability analyses. Of all dimensions, the GCP-dimension showed a low item-rest correlation $\left(r_{i t}=0.59\right)$, which could be a reason to omit this item from further literature reviews. This conclusion was confirmed by the value of Cronbach's alpha for the total scale after deletion of this GCP item: the alpha value without GCP was 0.88 , while the alpha value with GCP was considerably lower at 0.82 . Omitting the GCP-dimension will probably raise the reliability. This conclusion is confirmed by the correlation matrix (see Table 4), which shows Pearson's correlation between GCP and the total score to be relatively low $(r=0.64)$ compared with the correlation between the other dimensions and the total score. The correlations between the external and internal validity values with the total score were highest. 


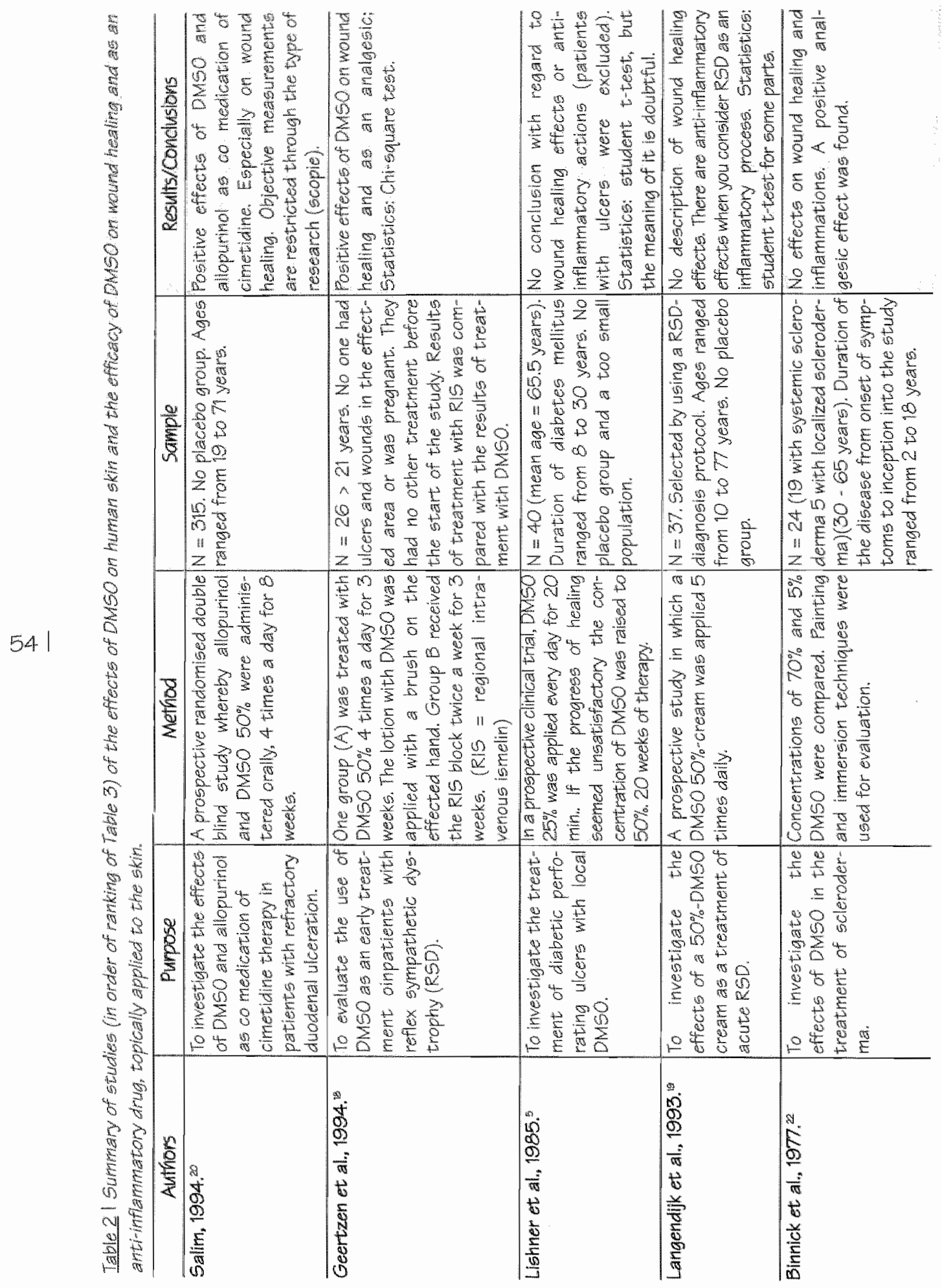




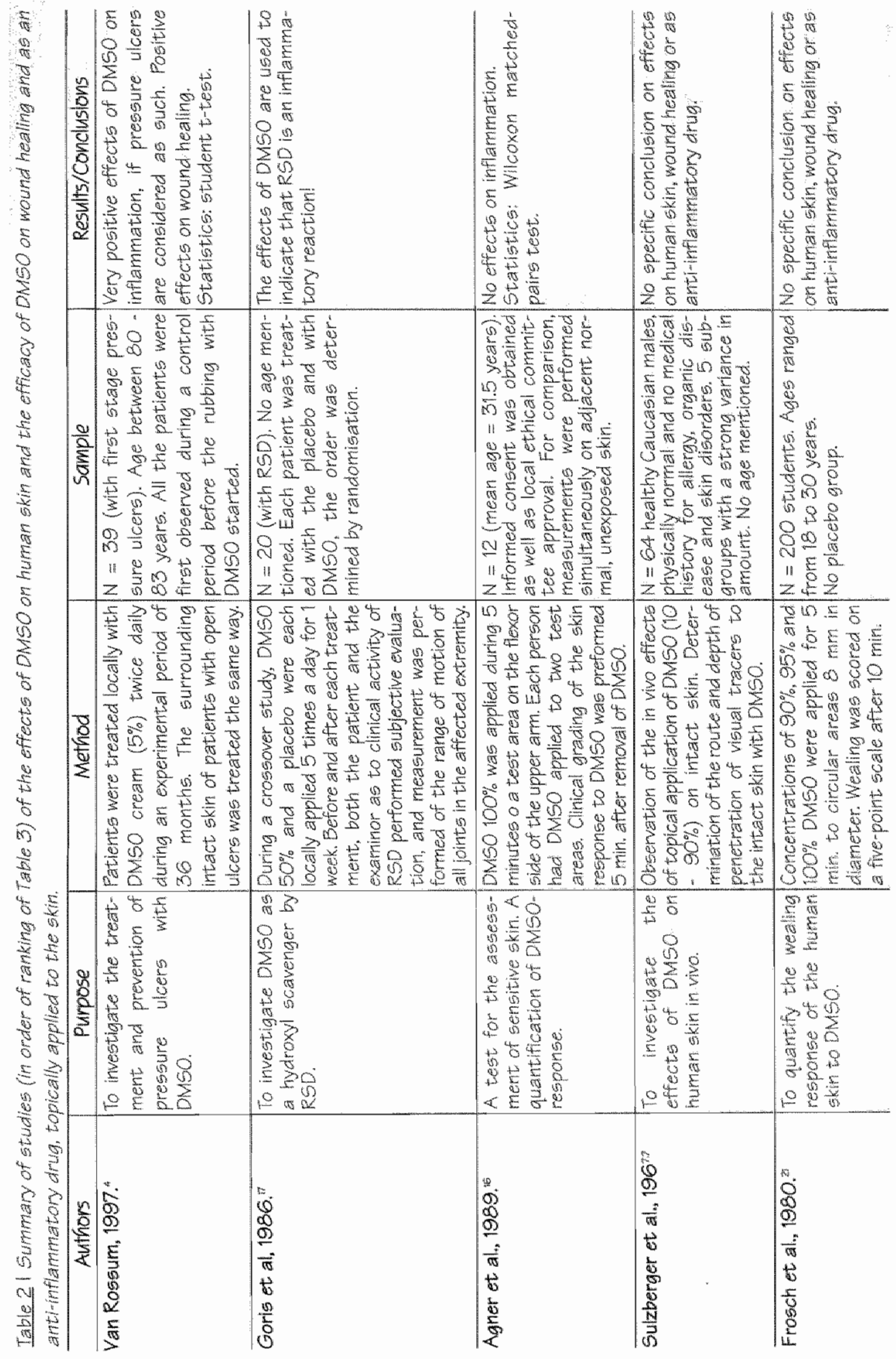




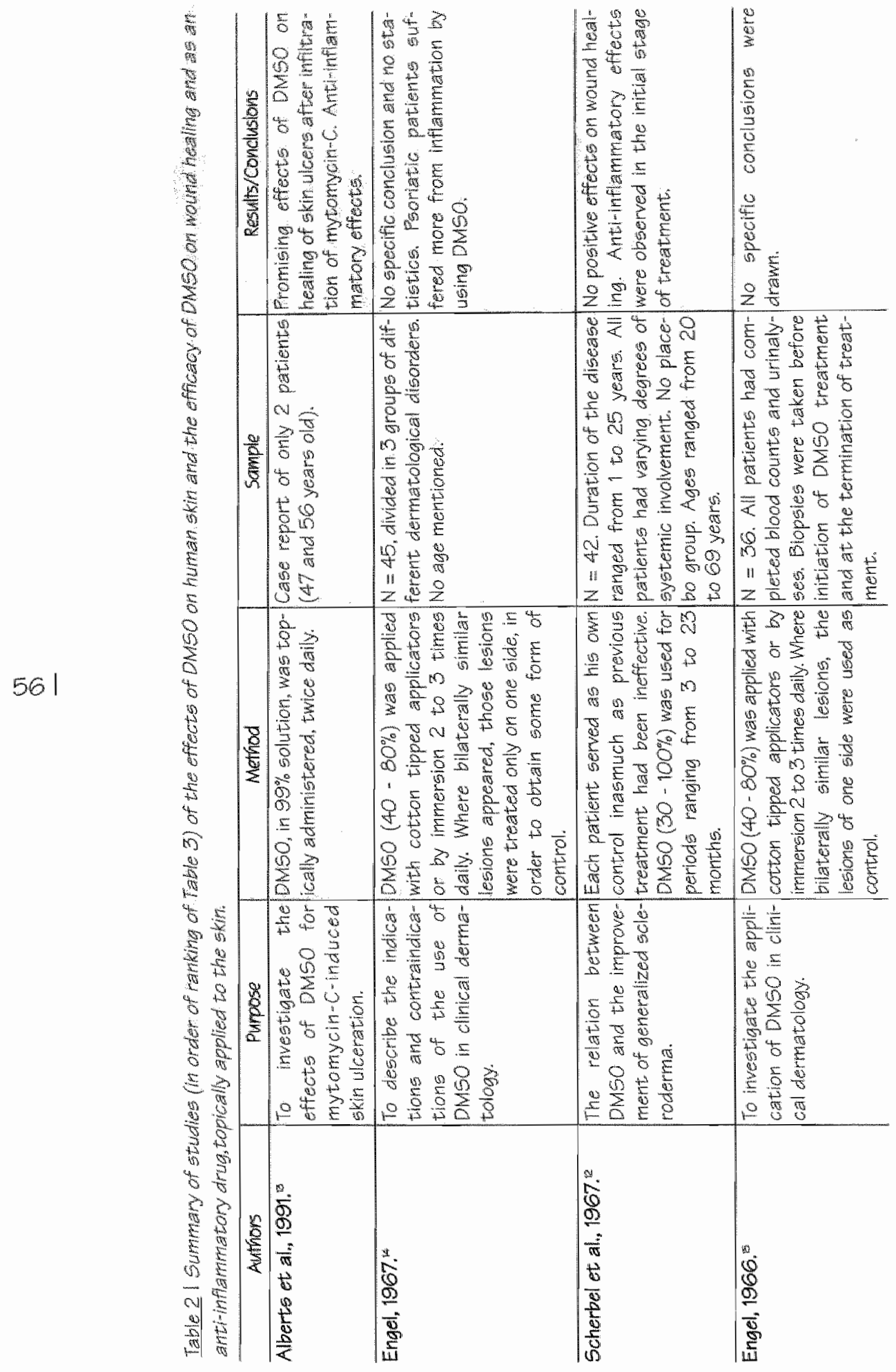




\section{4 | Discussion}

A review of the literature on experimental dermatological studies of the controlled trial type using DMSO revealed numerous studies using experimental animals. In contrast, dermatological studies with DMSO in humans have been scarce. The reason for this is not clear because the application of DMSO on the skin is not dangerous, causing only some occasional small side effects like itching and skin irritation, tingling or burning sensations and a bad breath (garlic odour). One possible explanation for the small number of studies in humans could be publication bias. The sample sizes of patients in these studies are very often too small, resulting in non-significant results, whether negative or positive.

The present literature search was undertaken to find out whether or not DMSO application could be effective in the treatment of pressure ulcers. Although various shortcomings of the studies that were reviewed blurred a clear conclusion on the efficacy of DMSO, we were able to identify sound results in 7 studies. The most important effects appeared to be anti-inflammatory effects, wound healing effects and pain relief. The 7 remaining studies recommended the use of DMSO, but did not provide sufficient information to allow reliable conclusions. The most important conclusion of the present review is that DMSO is effective as an anti-inflammatory and analgesic agent with positive effects on wound healing at concentrations equal to or larger than 5 percent. Furthermore, the treatment has to be continued for a minimum period of one week, and DMSO has to be applied two to three times a day. The main advantage of such a low concentration is that side effects are almost absent.

It is not clear if there are significant differences between various modes of application, e.g., spraying or rubbing, in the wound healing or anti-inflammatory effects. This was not investigated. We should bear in mind that rubbing introduces an additional variable, which could possibly affect inflammation, wound healing and pain relief.

In most of the studies, the interwention programme was implemented without the necessary relevant reference or placebo treatment. This preven-ted us from evaluating methodological quality of randomized controlled trials. 
Tale 31 Summary of the methodological assessment for each oriterion of the four different dindwolons of gualty

\begin{tabular}{|c|c|c|c|c|c|c|c|c|c|c|c|c|c|c|c|c|c|c|}
\hline \multirow{2}{*}{$\begin{array}{l}\text { Dimentione } \\
\text { Criteria }\end{array}$} & \multicolumn{5}{|c|}{ External Validity } & \multicolumn{5}{|c|}{ Internal valldity } & \multicolumn{3}{|c|}{ DPA } & \multicolumn{3}{|c|}{ GCP } & \multirow{4}{*}{$\begin{array}{c}\text { Total } \\
\text { Score } 80 \\
\text { whout } \\
\text { Gcp } \\
\left(p_{0} \mathrm{q}_{\mathrm{r}} \mathrm{s}\right)\end{array}$} & \multirow{4}{*}{$\begin{array}{c}\text { Total } \\
\text { Score } 87 \\
\text { wth } \\
\text { Gep } \\
(p, 9,6)\end{array}$} \\
\hline & a & $b$ & $c$ & a & $e$ & 19 & $1 n$ & 1 & 11 & \&) & Dint & $n$ & 0 & $p$ & 91 & 5 & & \\
\hline Max Weight & 3 & 10 & 10 & 5 & 2 & $5 \longdiv { 5 }$ & 5 & 7 & 5 & 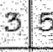 & 5 & 19 & 5 & 2 & 31 & 1 & & \\
\hline Study & & & 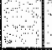 & & & & & & & & & & & & & & & \\
\hline Sallm & 3 & 10 & 3 & 5 & 2 & $5 \longdiv { 2 }$ & 5 & 5 & 48 & 3,0 & 3 & 5 & 3 & 2 & 21 & 1 & 65 & 7 \\
\hline Gertacn et alre & 2 & 6 & 7 & 8 & 1 & 4 & 8 & 5 & 3 & 36 & 5 & 3 & & 2 & $2 \longdiv { 1 1 }$ & 1 & 50 & 56 \\
\hline Lbhner et als & 8 & 8 & 8 & 5 & 2 & 43 & 3 & 1 & 28 & 2 & 2 & 3 & 3 & 2 & 2. & & 49 & 53 \\
\hline Langend $k$, et al & 3 & 7 & 3 & 4 & 2 & 3 & & 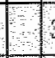 & 3 & 13 & 12 & 5 & 3 & 2 & 31 & & 39 & 45 \\
\hline Bunnuck et al.2\% & 1 & 6 & 6 & 5 & 3 & 31 & 2 & 1 & 4 & 7 & 1 & 11 & 3 & & 23 & 11 & 38 & 44 \\
\hline Van Rossum & 3 & 6 & 4 & 4 & 1 & 4 & & & 4 & 4 & 4 & & & 2 & 3 & & 34 & 38 \\
\hline Gorts, et al & 1 & 5 & 4 & 1 & 2 & 22 & 2 & & 2 & 12 & 2 & 2 & & 2 & 21 & 1 & 27 & 38 \\
\hline Agner and Serup! & 2 & 5 & 3 & 4 & 1 & 1 & & & & & 4 & 3 & 1 & 2 & 31 & 1 & 24 & 31 \\
\hline Sulzberger, et al.' & 2 & 3 & 8 & 5 & & 3 & & & & & 1 & 12 & & 2 & 3 & & 1 & 0 \\
\hline Frosch,et all & 1 & 3 & 2 & & 2 & & & & & & & & & 2 & 3 & & 8 & 13 \\
\hline Alberts and Dort' & & & 5 & 3 & 3 & 1 & & & & & & & & 2 & 2 & & 10 & 14 \\
\hline Engelt & & 2 & 2 & 2 & 1 & & & & & 1 & & 8 & & 1 & 4 & & 8 & 10 \\
\hline Scherbal, et al & 1 & 1 & & & 1 & & & & & 1 & & 3 & & 1 & 2 & & 7 & 10 \\
\hline Engelo & & & 2 & & 1 & & & & & & & 11 & & 1 & 2 & & 4 & 7 \\
\hline Mean & & & 4.36 & & & & & 82 & & & & 4.7 & & & 486 & & 28 & 3214 \\
\hline sud Deviation & & & 775 & & & & & 886 & & & & 379 & & & 1.46 & & 9.18 & 20.08 \\
\hline
\end{tabular}

KCP = Good dinical practice, WDPA - Dota presentation and analyses

which we would have preferred to do in order to avold conclusions based on trials of inferior methodological quality. We therefore decided to evaluate the studies that were included according to four dimensions instead of one methodological scale.

Furthermore, a comsiderable amount of information, that would have been relevant to the evaluation of the methodological quality, seemed to be missing. Al1 adequate description of the randomisation procedure is very important, as randomisation/matching is necessary to prevent selection bias. An adequate description of such randomisation was provided in only 4 of the articles, while 3 others gave some information. It should be pointed out that ever the use of an adequate randomisation procedure does not guarantee equal distribution of prognostic factors and confounding variables among the study groups, particularly if the groups are relatively small. 
Table 4 The correlationmeth

\begin{tabular}{|c|c|c|c|c|c|}
\hline & $\begin{array}{l}\text { Extemal } \\
\text { Vallidity }\end{array}$ & $\begin{array}{l}\text { Intemal } \\
\text { Validiby }\end{array}$ & $\begin{array}{l}\text { Data Presenthation } \\
\text { and Arulyses }\end{array}$ & $\begin{array}{l}\text { Good Clinical } \\
\text { Practice }\end{array}$ & $\begin{array}{l}\text { Total } \\
\text { Score }\end{array}$ \\
\hline Extemal Vallatity & 1 & & 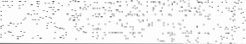 & & \\
\hline Intemal Validity & .643 & 1 & & & \\
\hline $\begin{array}{c}\text { Data Presentation } \\
\text { and Analyses }\end{array}$ & 818 & 760 & 1 & & \\
\hline $\begin{array}{c}\text { Good Clinical } \\
\text { Practice }\end{array}$ & .60 & 466 & 675 & 1 & \\
\hline Total Scone & .957 & 94 & 689 & 641 & 1 \\
\hline
\end{tabular}

Information about the participants and baseline walues of outcome meas. ures was indicative of the success of the randomisation procedure. Seven articles reported at least some of the baseline characteristics. Six articles provided a description of co-interventions.

Almost all the articles (13 of 14 ) presented relevant outcome measures of which pain relief and less dolor as an inflammation symptom differed from patient to patient because of its subjective character, but only 2 of the studies had applied a blinded assessment to them.

Thirteen articles reported side effects. Aithough slde effects were often considered to be moderate or mild in the studies evaluated here, a small number of participants discontinued application of DMSO because of adverse reactions.

This review did not include an assessment of the quality of the outcome measures as the outcome measures included in our criteria list for methodological assessment of these studies could not be ranked in a priority list. Our list included the most important ones based on literature findings; most of these measures probably have been designed on the basis of face validity. The studies reviewed were given one point for each outcome measure reported. Only 5 articles mentioned the presence of an informed consent procedure and approval by a medical ethics committee. One article mentioned the presence of an informed consent procedure only.

The interpretation of the efficacy of DMSO depends partly on information on the use of co-interventions and the participants adherence to the treatment regimen. As mentioned above, 6 anticles described the use or absence of co-interventions; the others presented little information about the use of cominterventions. Seven articles described dropout rates. 
Although the studies were based on small samples and often lacked reference groups, we can conclude that it seems safe to use DMSO on the human skin, either by rubbing or by spraying. The indication is to use DMSO in concentrations less than 50 percent because of the increasing risk of side effects at concentrations exceeding 50 percent. At concentrations below 50 percent. DMSO has favorable effects on inflammation and wound healing, as well as an analgesic effect, which is of course also an important aspect for the patient.

5 | References

1. Bours GJJW, Halfens RJG, Huijer Abu-Saad H, Grol RTPM. Prevalence, prevention and treatment of pressure ulcers: a descriptive study in 89 institutions in the Netherlands. Research in Nursing and Health 2002; 25(2):99-110.

2. Houwing R, Overgoor M, Kon M. Jansen $G$, van Asbeck BS, Haalboom JRE. Pressure-induced skin lesions in pigs: reperfusion injury and the effects of vitamin C. Journal of Wound Care 2000;9(1):36-40.

3. Four-Grade System. Presented at the European Pressure Ulcer Advisory Panel (EPUAP) meeting, Oxford, UK, September 20-22, 1998.

4. Van Rossum, JP. Behandeling en preventie van decubitus met dimethylsul foxide - verslag van een pilot studie (Treatment and prevention of decubi tus with dimethyl sulphoxide - a report of a pilot-study). Unpublished report, personal communication, 1997.

5. Lishmer M, Lang R, Kedar 1, Ravid M. Treatment of diabetic perforating ulcers (mal perforant) with local dimethyl sulfoxide. J Am Geriatr Soc $1985: 33,41-3$.

6. Kedar I, Jacob E, Ravid M. Dimethylsulfoxide in acute ischaemia of the kid ney: experimental models in the rat and in the dog. Ann NY Acad Sci 1983:411:131.

7. Sulzberger MB, Cortese TA, Fishman L. Some effects of DMSO on human skin in vivo. Ann NY Acad Sci 1967;141(1),437-50. 
8. Kappert A. Experimental and cilicical evaluation of toploal dimethyl sulfox ide in venous disorders of the extremities. An N Acad 601975 . $243: 403-7$

9. Feinstein AR. Climical epidemiology: the architecture of clinical research. Philadelphia: W.B. Saunders: 1985.

10. Bouter LM, van Dongen MCJM. Epidemiologisch onderzoek: opzet en inter pretatie (Epidemiologic research. Principles and methods). Houtem/Diegem: Bohn Stafleu Van Loghum:1995:183-6.

11. Assendelft. WJJ, Schotten RJPM, van Eijk JTM, Bouter LM. De praktijk van systematische reviews III. Methodologische beoordeling vam onderzoeken (The practice of systematic reviews. A methodological assessment of research). Ned Tijdschr Geneeskd 1999;143(14):714-18.

12. Scherbel AL, MaCormack LJ. Layle JK. Further observations on the effect of dimethyl sulfoxide in patients with generalized scleroderma (progres sive systemic sclerosis). Ann NY Acad Sci 1967;141(1):613-29.

13. Aiberts DS, Darr RT. Case Report: Topical DMSO far Mitonycin-c-Induced Skin Ulceration. Oncol Nurs Forum 1991:18:693-5.

14. Engel MF. Indications and contraindications for the use of DMSO in clini cal dermatology. Ann NY Acad Sci 1967;141(1):638-45.

15. Engel MF. Dimethyl Sulfoxide (DMSO) in Clinical Dermatology. South Med I $1966,59(10): 1318-20$.

16. Agner T, Serup J. Quantification of the DMSO-response, a test for assessment of sensitive skin. Clin Exp Dermatol 1989:14:214 17.

17. Goris RJA, Dongen LMV, Winters HAH. Are toxic oxygen radicals involved in the pathogenesis of reflex sympathetic dystrophy? Free Radic Res $1986 ; 3(1-5): 13-8$

18. Geertzen JHB, de Bruijn H, de Brulin-Kofman AT, Arendzen JH. Reflex Sympathetic Dystrophy: Eanly Treatment and Psychological Aspects. Arch Phys Med Rehabil 1994;75:442-5.

19. Langendijk PNJ, Zuumond WWA, Van Apeldoom HAC, Van Loemen AC, De Lange Ju. Goede resultaten van behandeling van acute reflectoir-sympa thische dystrofie met een $50 \%$-dimethylsulfoxide-creme (Good results of the treatment of acute Reflex Sympathetic Dystrophy by using a $50 \%$ dimethyl sulfoxide cream). Ned Tijdschr Geneeskd 1993:137(10):500-3. 
20.Salim AS. Role of Free Radical Scavengers in the Management of Refractory Duodenal Ulceration. J Surg Res 1994;56:45-52.

21. Frosch PJ, Duncan S, Kligman AM. Cutaneous biometrics I. The response of human skin to dimethyl sulphoxide. Br J Dermatol 1980:102:263-73.

22. Binnick SA, Shore SS, Corman A, Fleishmajer R. Failure of Dimethyl Sulfoxide in the Treatment of Scleroderma. Arch Dermatol Res 1977:113:1398-1402.

621 


\section{Chapter 4}

\section{Massage to prevent pressure ulcers: knowledge, beliefs and practice.}

\section{A cross-sectional study among nurses in the Netherlands, in 1991 and 2003.}

Hnge GP Duimel-Peeters, Mirjam A Hulsenboom, Martinn PF Berger; LuC HEH Snoeckx, Ruud JG Halfens

Background: Pressure ulcers are a major problem in all areas of health care in the Netherlands. National guidelines for the prevention and treatment of pressure ulcers were originally developed in 1985, and revised in 1991 and 2002 . The value of these guidelines can be questioned because it seems there are not in line with the bellefs and practice of the caregivers, and not all of them are evidence-based. Aims and objectives: To get a better insight into nurses' current knowledge, beliefs and performed practices relating to massage, a study was designed to assess changes in these three aspects after the publication of the 2002 Dutch national guidelines. "The outcome was compared to the situation in 1991. Design and Method: A cross-5ectional comparative study was designed using written questionnaines. Questions were fommlated regarding knowledge, and beliefs about prevention methods and the actu al use of these methods in the prevention of pressure ulcers. The 2003 survey pop. ulation consisted of nurses working in the Netherlands and was approached at ran dom via subscriptions to Nursing News (i.e. Verpleegkunde Nieuws), a Dutch professional jourmal or via affiliations to an institution participating in the 2003 Dutch National Prevalence Survey of Pressure Ulcers. Results and Conclusions: Compared with the 1991 findings, the 2003 results show an improvement for the topic of pressure ulcers, but a deterioration regarding debydration. It is obwious that the knowledge of the current. CBO-guidelines on massage is still not widely distributed as it should be. Our overall conclusion is that the differences in responses between 1991 and 2003 are significant, and suggest that the nurses were better informed in 2003. Relevance to clinical practice: For the improvement of health care in the domain of pressure ulcer preventions, we need more than an accurate implementation of new or existing guidelines. Guidelines should also be based on qualitative, method ological well designed studies to be evidence-based. 
$P$ ressure ulcers (PU) are a major problem in all areas of health care in the Netherlands. Estimations for 1998 revealed that more than $\%$ of the total health care budget was spent on prevention and treatment of pressure ulcers. These ulcers are a common and painful condition among immobilised and debilitated patients and cause a great deal of suffering and frustration, not only to the patients themselwes but also to their relatives and caregivers.

Although various prewentwe measures are being used by nurses and caregivers ${ }^{(13,4)}$, what is used in practice does not necessarily correspond to what is theoretically recommended. ${ }^{(5.6)}$ In order to bring more structure in the nursing practice, Dutch experts have collated their relevant knowledge in this domain into national guidelines for the prevention and treatment of pressure ulcers. Originally developed in 1985, these guidelines were revised in 1991, and ance again in 2002 "In recent years, the attention paid to the problem of pressure ulcers has increased steadily as a result of the annual Dutch prevalence registrations, several publications in professional journals and last but mot least, improved pressure ulcer consultancy in health care institutions.

In spite of all these efforts, some contradictory beliefs about the use and benefits of preventive methods persist in guidelines, practice and the litera* ture. One of the commonly applied preventive methods is massage, which is described in national and intemational guidelines for the prevention of pressure ulcers as "not usefur ". Nevertheless, a survey held in Dutch hospitals shows that almost all murses evaluated massage as an effective method. which was a reason for them to go on applying this treatment. Comparable results were found among health care workers in nursing homes.

This example shows that the national guidelines do not correspond to nurses' beliefs. In addition to this, a recent literature study about the effectiveness of massage in the prevention of pressure ulcers shows that the number of studies on this topic is very limited and that the existing studies are often of poor methodological quality. "Therefore, the tendency to adopt. these guidelines in practice could be very limited. 
In order to examine nurses' current knowledge, beliefs and performed practices relating to massage, a study was designed to assess changes in these three aspects after the publication of the 2002 national guidelines (as drawn up by the Dutch institute for Healthcare Improvement ${ }^{(4)}$ ). The outcome was compared to the situation in 1991, the year in which the previous guide lines were published. ${ }^{(4,13)}$ We also explored whether changes in knowledge and/or beliefs had had any effect on everyday practice.

21 Guidelines on massage

The 1991 and 2002 Dutch CBO-guidelines classify the techmiques or methods to prevent the development of pressure ulcers into two groups i.e. "useful' and 'not useful". Both sets of guidelines describe skin massage as not useful for the prevention of pressure ulcers, but beneficlal for the prevention of dehydration. ${ }^{(+.3)}$ The Belgian guidelines are also explicit on this point: 'Do not perform any kind of skin massage on pressure points, not even with ice.". In its statement on Pressure Ulcer Prevention the National Pressure Ulcer Advisory Panel of the U.S. confirmed that cleaning and moisturising all skin surfaces is important and that aggressive massage should be avoided in order to prevent tissue damage. The European Pressure Ulcer Advisory Panel states: 'Avoid excessive rubbing over bony prominences as this does not prevent pressure damage and may cause additional damage." Finally, the U.S. Agency for Health Care Policy and Research is positive about the use of crearns and oils to prevent dry skin but advises against massaging the skin over bony body parts. Massage may squeeze and damage the tissue under the skin and make the patient more prone to develop pressure ulcers.

3 I Research questions

The present study tried to answer the following questions:

\section{Regarding knowledge:}

What do nurses know about the use of massage as described in the 2002 CBO guidelines? 


\section{Regarding beliefs:}

Would nurses still like to use massage to prevent pressure ulcers in patients at high-risk of such ulcers?

\section{Regarding practice:}

Do nurses actually administer massage to prevent pressure ulcers in patients at high-risk patients of such ulcers?

Has there been a change in knowledge, beliefs and practice relating to massage between 1991 and 2003 ?

4 I Methods

\section{Design}

A cross.sectional comparative study was designed using written questionnaires among 529 nurses. Questions were fom mated regarding knowledge and bellefs about prevention methods and the actual use of these methods in the prevention of pressure ulcers.

\section{Measurement instrument}

The present survey (2003) used a written questionnaire, comparable to that of 1991 , to collect the data. The 2003 questionnaire was divided into 7 themes. For our analysis, we used only the first 4 themes, which were the same as those used in 1991, i.e.;

(1) General questions concerning age, sex, education, work experience, and work situation:

(2) Questions regarding practice: respondents were presented with a list of preventive methods and were asked to indicate which ones they used in practice. Only the following 2 items were used for analysis: 'massaging the skin' and 'smearing the skin with local agents to prevent dehydration'. Answering categories were 'always", "sometimes" and "never".

(3) Questions regarding advice: respondents were presented with the same list of preventive methods, but were now asked to indicate which methods they would recommend to prevent pressure ulcers. The same 2 items referred to above were used for analysis, with the same 3 answering categories. 
(4) Questions regarding knowledge respondents were presented with the same list of preventive methods, and were asked to evaluate each preventive method in terms of its being "useful', "sometimes useful" or "not useful'; they could also indicate that they did not know whether a method was useful or not. Again, only the 2 items mentioned above were used for the analysis. Other preventive methods were not included in the analysis because they either had nothing to do with massaging, rubbing, or smearing or were not included in the CBO-guidelines to which we wanted to refer.

Three additional questions dealt with aspects of the policy on pressure ulcers in place at the nurses' institution, the availability of nursing journals at their ward, opportunities to participate in training courses and finally, questions regarding the awareness of the new 2002 CBO guidelines.

Our analyses focused on the outcomes of massage for pressure ulcers and compared these outcomes with those of smearing the skin to prevent dehydration.

\section{Population}

The 2003 survey population consisted of nurses and other health care providers working in the Netherlands. The survey sample consisted of a total of 2536 persons, 976 of whom were approached at random via their subscription to Verpleegkunde Nieuws (Nursing News), a Dutch professional journal for nurses which has 20.000 subscribers. Another 1560 nurses were selected at random via their affiliation to an institution participating in the 2003 National Prevalence Survey of Pressure Sores. At first, 1332 questionnaires were returned (511 by Verpleegkunde Nieuws subscribers (5235\% response rate) and 821 by employees of institutions (52.62\% response rate)). Of these 1332 questionnaires, 1140 ( $85.6 \%$ ) met our inclusion criteria, which consisted of being involved in direct patient care and not working on more than one ward of the same institution. Of the 1140 questionnaires, 74 were not or only partially completed. Eventually, of the remaining 1066 $(80.6 \%)$ questionnaires, 529 were used for final analysis because the respondents had an educational background and working environment that was comparable to that of the nurses in the 1991 survey. The working environ. 
ment of all 529 respondents in 2003 (all registered nurses) is given in Table 1. While Table 2 shows the working environment of the participants of the 1991 survey. (Categorical hospitals ane hospitals providing one specific medical specialization.)

\begin{tabular}{|c|c|c|}
\hline Institution & Frequency $(\mathrm{N}=529)$ & Percent \\
\hline Academic Hospital & 73 & 13.8 \\
\hline General Hospital & 451 & 85.3 \\
\hline Categorical Hospital & 5 & 0.9 \\
\hline
\end{tabular}

Table 1 | Distribution of the 2003 -respondents in terms of working environment.

\begin{tabular}{|c|c|c|}
\hline Institution & Frequency $(\mathrm{N}=529)$ & Percent \\
\hline Academic Hospital & 74 & 19.8 \\
\hline General Hospital & 289 & 77.5 \\
Categorical Hospital & 10 & 2.7 \\
\hline
\end{tabular}

Table 2 I Distribution of the 1991-respondents in terms of working environment.

The 2003 population consisted of $83.7 \%$ women (i.e., 443 women, with $1.7 \%$ missing data for the 529 respondents); versus $88.5 \%$ in 1991 (i.e., 330 women, with $0.3 \%$ missing data for the 373 respondents). The mean age in 2003 was 35.5 years compared to 32.5 in 1991 (0.5\% missing data for 373 respondents).

5 Results

Table 3 presents the 1991 and 2003 results as regards practice, beliefs and knowledge relating to massage to prevent pressure ulcers and smearing the skin to prevent dehydration. First of all, the results show a dramatic and sigmificant change in practice, beliefs and knowledge in this respect. Whereas in 1991, almost all nurses (87.4\%) reported that they "always" or '5ometimes' used massage, this percentage had been reduced to $48.9 \%$ in 2003 . 
Although this is a remarkable reduction, it should be noted that this means that almost one in two numses (48.9\%) still used massage as a prevertive method for pressure ulcers in 2003 . Comparable results were found for the beliefs and knowledge relating to the use of massage for preventing pressure ulcers.

The knowledge, beliefs and practice relating to smearing the skin with local agents to limit dehydration had also changed, but not as dramatically as those for massage to prevent pressure ulcers. Here, a shift had occurred between the 'always' and 'sometimes' categories, in the sense that in 2003 more nurses used smearing "sometimes', while in 1991 more nurses used it 'always'. All differences between 1991 and 2003 , for both methods, were statistically significant ( $p<.0001$, using t-tests for independent samples).

Possible influences of sex, age, years of work experience and working environment on the practice, beliefs and knowledge relating to massage to prevent pressure ulcers and dehydration were analysed for 1991 and 2003 using the Mann-Whitney and Kruskal-Wallis tests. For 1991, a significant relation was found between smearing the skin to prevent dehydration and the number of years of work experience $(p=.019)$. A signiflicant relation was also found between the belief that massage is useful to prevent pressure ulcers and the respondents' sex $(p=019)$. For 2003 , significant relations were found between the practice of smearing the skin to prevent dehydration and the respondents' ages $(p=.007)$ and working enviromment $(p=.022)$. There was a significant difference between men and women as regards the belief that smearing the skin is useful to prevent dehydration $(p=.010)$. Finally, a significant difference was found between the various ages as regards knowledge about massage to prevent pressure ulcers $(p=.038)$. Table 5 summarizes all Findings.

Because it was impossible to categorise the data into equal intervals, we used the Spearman correlation coefficient instead of the usual Pearson correlation coefficient, to a5sess possible relationships between varlables. Spearman correlations were calculated to assess whether the 2003 survey data showed a relation between actual practice on the one hand and beliefs and knowledge on the other. The relation between use of massage and the 
bellef that massage is useful to prevent pressure ulcers yielded a Spearman correlation of 0.537 , which was comparable to that for 1991 (0.539). The 2003 relation between use of massage and knowledge about massage for the same purpose yielded a Spearman correlation of 0.492 , against 0.500 in 1991. Finally, the strongest relation, in 2003 as well as 1991, was that between the belief that massage is useful and knowledge about massage for the prevention of pressure ulcers: 0.655 and 0.666 , respectively.

The correlations for the other purpose, preventing dehydration by smearing the skin, are summarised in Table 4. 


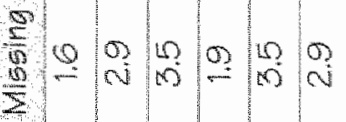

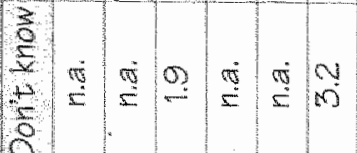

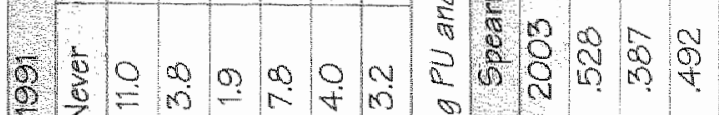

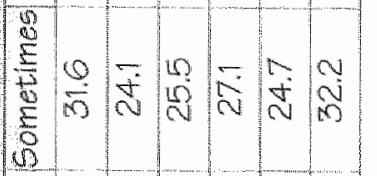
$200 \times 10 / 00 \%$ t. \begin{tabular}{l|l|l|l|l|l|l}
3 & 10 & 8 & 0 & 0 & 0 & 0
\end{tabular}

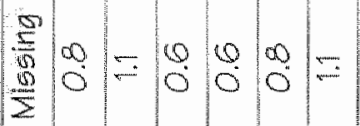

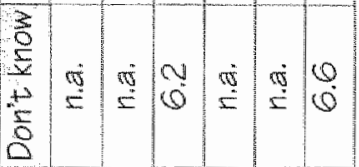

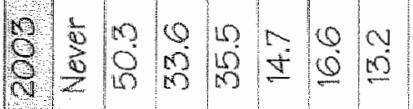

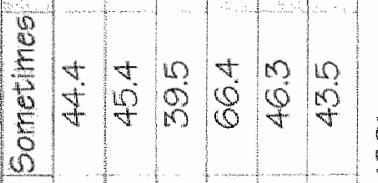

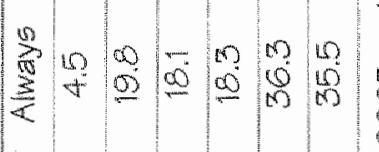

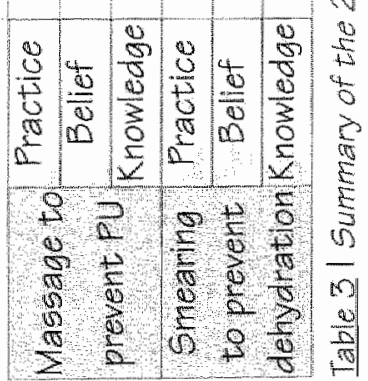

$\frac{5}{9} \frac{0}{4} \log$

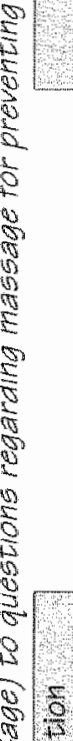

so

$\frac{2}{2} 140.50$

$\frac{29}{6} \sqrt{\frac{2}{3}} / \frac{0}{5}$

$301 \frac{9}{8}$

$3 \mathrm{~B} / \mathrm{s}^{2}$

3.

$8 a ^ { 2 } \longdiv { 2 0 }$ की $1 0 \longdiv { 0 }$

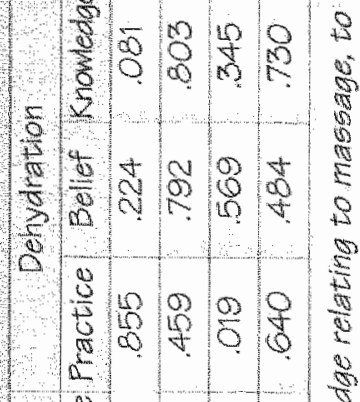

एक

$60 \frac{1}{2}$

is

E $\left.5\right|^{2}$

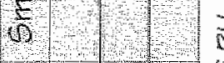

$5 \log 0$

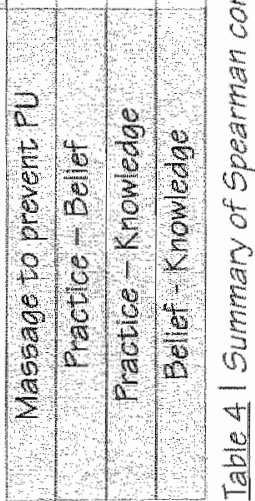




\section{6 loiscussion}

Compared with the 1991 findings, the 2003 results show a positive development for the topic of pressure ulcers, but a deterioration regarding dehydration. It is obvious that the awareness of the current CBO guidelines on massage is still not widely distributed. There was a large variance in the frequency of the answers relating to knowledge. More than one third of the nurses $(39.5 \%$ ) reported that they thought that massage is sometimes indicated for high-risk patients. Findings in terms of actual use in practice were comparable, in that a large part of the group ( $44.4 \%$ ) reported that they sometimes applied massage to prevent high-risk patients developing pressure ulcers, although only $4.5 \%$ said that they always used this method.

The current expert opinion is that massage as a preventive treatment for pressure ulcers could be harmful to underlying tissues. From our survey, it seems that this knowledge has insufficiently reached the wards. Patients are still being treated with what according to the CBO guidelines are non-useful interventions, and are undergoing possibly harmful treatments. However, it must also be pointed out that the results about the possible damage caused by massage are still not significant. Further research, supported by statistically proven quantitative data, is therefore strongly recommended.

In the 1991 surwey, $55.8 \%$ of the nurses always applied massage to patients at high risk of developing pressure uicers. Another $31.6 \%$ reported massaging sometimes, which means that at that time only $11.0 \%$ may have been aware of the CBO guideline when they said that massage should never be performed. In 2003, it seems at least that nurses on the ward no longer consistently appiy massage to every high-risk patient. It is questionable, however, whether this is entirely the result of awareness of the new CBO guidelines, in view of the rather large percentage of nurses (4.4.4\%) who still apply massage in some cases. A possible alternative explanation for not 'always' massaging may be the increased workload, as it is generally accepted that the workload for nurses in the type of health care centres included in our survey has increased considerably over the last 5 years.

Compared with 1991, fewer nurses in the 2003 survey said they believed 
in massage (19.8\% versus $69.2 \%$ ), while more reported not believing in massage $(33.6 \%$ versus $3.8 \%$ ), and $45.4 \%$ believed that massage is sometimes useful. Apparently, opinions among both believers and non-believers were stronger in 1991, as 45.4\% of the 2003 respondents answered 'sometimes'. This could be a result of increased workload, or of doubt, or of more individual patient-oriented health care.

The 2003 survey results suggest that nurses had become more aware of the content of the CBO-guidelines on massage since 1991. Of the respondents in the 2003 survey, $18.1 \%$ reported that massage was regarded as a useful method - which it is not - against $67.3 \%$ in 1991. But the 2003 data also show that more nurses $(6.2 \%)$ admitted not to know exactly what the CBO guidelines recommend than in 1991 (1.9\%). Athough at first sight, it, thus seems that 2003 scores were 'better", a large part of the 'always'-group had shifted to the 'sometimes'-group, which again could be a result of increased doubt or of more patient-oriented health care.

The computed Spearman correlations are all relatively low with the exception of those between believing in massage and knowledge about massage, both in 2003 and 1991 . Although in 2003. 19.8\% of the nurses tended to believe in the beneficial effect of massage, only $4.5 \%$ actualy applied massage in practice. This may have been due to work load but could also mean that more nurses did not apply massage in practice (50.3\%), while only $33.6 \%$ were prepared to admit that they did not believe in the technique. The same conclusion can be drawn for the correlation between applying massage in practice and knowledge about massage. In 2003. more nurses reported never using massage (50.3\%), while only $35.5 \%$ said they knew that massage is not useful. The highest correlations were found for the variables knowledge and belief: 0.655 for 2003 versus 0.666 for 1991 . Apparently, it is more obvious to detect some correlation between the two "theoretical" questions, i.e. those on belief and knowledge, than between one of them and actual practice. This could confirm our conclusion that it is not only evidence-based knowledge and belief that determine what happens in practice, but that other variables are also involved such as the influence of traditional knowledge, the personal-and team involvement, the familiarity with guidelines and the used 
implementation-strategy through the management-teams. A very important variable, from personal perspective, seems to be the increased workload in recent years which is a major subject in the current debate on quality of care.

The opposite conclusions can be drawn as regards the nurses attitude about skin smearing for the prevention of dehydration, which is defined by the CBO guidelines as a useful method. Knowledge about this appears to have been better in 1991 than in 2003. In 1991, 58.4\% of all respondents answered that they knew that smearing the skin is always useful to prevent dehyaration, while $63.3 \%$ also reported that they always used this method. In 2003. $35.5 \%$ of the nurses said they knew that smearing for this purpose was useful, whereas only 18.3\% actually applied it. Again, the differences in practice may have been influenced by the increased workload. Our findings suggest that nurses are well aware of some of the contradictions concerning the practice of massage, as well as of the debate on this topic in the scientific world, but that they are not able to put their finger on it. This could explain the sometimes umexpected shifts in behaviour.

Some methodological issues regarding the present study must be addressed. First, there may have been some information bias. Using a questionnaire instead of observations means that it is not clear whether the answers accurately represent reality. Although the questionnaire was anonymous, it is possible that respondents may have given so-called 'socially desirable answers' or at least what they thought were socially desirable answers. This could explain the high frequencies of "sometimes" answers, indicating that respondents do not really know what to answer (the answer do not know' was not always an option). The assumption that the answers reflect actual reality may have consequences for the validity of the conclusions. Furthermore, we assume that the $N$ as well as for the 1991-surwey as for the 2003-survey is large enough to overcome any possible sampling bias.

An important commert must further be made regarding the terms massaging the skin" and smearing the skin'. It is not always fully clear what people mean by these terms, neither in the literature, nor on the wards, nor in our questionnaires. It is possible that nurses report smearing patients' skin to 
prevent dehydration but actualy mean massaging or rubbing the skin, and vice versa. The CBO guidelines themselves also fall to provide specific definitoris of these terms.

The findings of this study show a gap between theory and daly practice in the care of patients prone to pressure ulcers. The literature mentions several factors that may explain this gap. Kitson et al ${ }^{60}$ divided these factors into three categories, mamely evidence, context and facilitation. Berwick used these factors in comparable categories: perceptions of the innovation, characteristics of individuals, and contextual factors. In the present case, one factor which could have caused the gap could be the evidence upon which the Dutch CBO guidelines are based. Although the 2002 CBO guidelines are more evidence-based than previous guidelines, only $5 \%$ of the guidelines are really evidence-based.

Another factor could be the degree of facilitation. Although the guidelines have been sent to all health care institutions, and reported in professional Joumals, there may have not been enough active facilitation within the institutions. Berwick ${ }^{(2))}$ stated that simple innovations spread faster than complicated ones, and guidelines often represent an overview of the state of the art, with a large number of recommendations. Reducing the recommendations to, for instance, the two or three most relevant ones, might considerably speed up adoption. The context, for instance in terms of an innovative culture, is also important. Buss et al. showed that the contextual factors in Dutch nursing homes do not facilitate the adoption of pressure ulcers guidelines.

Finally, it would be of great interest to examine the situation regarding this issue in other countries. As mentioned earlier, the EPUAP guidelines and the national Dutch guidelines both agree that massage is not useful. Therefore, it might be useful to know what the actual practice regarding pressure ulcer prevention is like in other European countries. Research about the relation between national guidelines and actual national performed practice could give us more insight into the effectiveness of guideline implementation strategles and their influence on practice. 


\section{Conclusion}

Our overall conclusion is that the differences between the responses to our questionnaires on massage to prevent pressure ulcers in 1991 and 2003 are significant, and suggest that the nurses were better informed in 2003. The greatest shift in frequencies was that from the 'always using massage' to the 'sometimes using massage' category. Since implementation requires a match between the perception of guidelines, the context and the adopters. the new guideline could have influenced this result positively. However, other factors may also have intervened, such as the context, the adopters and the way guidelines have been presented.

Although implementation of guidelines is an important topic and further research is needed for an understanding of effective strategies: further improvement of health care in the domain of pressure ulcer preventions requires more than accurate implementation of new or existing guidelines. Guidelines should also be evidence-based, that is based on qualitative, methodologically well designed studies. There is thus a meed for more studies of this kind. In addition, there is also a need for good definitions of the terms 'massage' and 'skin smearing' to ensure that the answers to questionnaires really reflect what happens in practice.

$8 \mid$ References

1. Bours GJJW, Halfens RJG. Huijer Abu-Saad H, Grol RTPM. Prevalence, prevention and treatment of pressure ulcers: A descriptive study in 89 institutions in The Netherlands. Research in Nursing and Heaith 2002;25:99-110.

2. Bours GJJW. Pressure Lllcers: Prevalence measurements as a tool for improving care [PhD-Thesis]. Maastricht: Universiteit Maastricht;2003.

3. AHCPR, Research AfHCPa. Pressure ulcers in adults: prediction and prevention. U.S. Department of Health and Human Services, Public Health Service, Agency for Health Care Policy and Research;1992 May.

4. CBO, Toetsing CBrdl. Richtlijn Decubitus. (Guidelines on pressure ulcers.) Centraal Begeleidingsorgaan voor de Intercollegiale Toetsing 
(Dutch Institute for Healthcare improvement);2002.

5. Haifens RJG, Eggink M. Knowledge, beliefs and use of mursing methods in preventing pressure sores in Dutch hospitals. International Journal of Nursing Studies 1995;32:16-26.

6. Hulsenboom MA. Decubituspreventie door de jaren heer. Een vergelijking van de kennis en inzet van preventieve maatregelen bij decubitus door verpleegkundigen en verzorgenden. (Prevention of Pressure Uicers. A comparison of the knowledge and use of preventive methods, through nurses and health care givers, for pessure ulcers.)[Master-Thesis]. Maastricht:Universiteit Maastricht;2004.

7. CBO, Toetsing CBval. Consensus preventie van decubitus. (Consensus on pressure sore prevention.). Centraal Begeleidingsorgalan voor de Intercollegiale Toetsing, (Dutch Institute for Healthcare Improvement); 1985.

8. CBO, Toetsing CBvdl. Herziening consensus decubitus. (Revision of pressure sore consensus.). Centraal Begeleidingsorgaan voor de Intercollegiale Toetsing, (Dutch Institute for Healthcare Improvement);1992.

9. Bours GJJW, Halfens RJIG, de Winter A. Landelijk prevalentie onderzoek decubitus : uitgebreide resultaten eerste jaarlijkse meting 1998. (Annual Dutch Prevalence Pressure Ulcer Survey: results of the first annual survey (1998)). Universiteit Mastricht, Dep. Health Care Studies / Section Nursing Science:1998.

10. Buss IC, Halfens RJG. Knowledge of (enrolled) nurses working in Dutch nursing homes about pressure sores prevention: introduction [poster]. Education : experiences we can share: 5th European Pressure Ulcer Advisory Panel open meeting (2001).

11. Belgische-Werkgroep-Kwaliteitszorg-Preventie-en-Behandeling-Decubitus (1995). Samen kunnen wij doorligwonden woorkomen: een bondige en praktische brochure voor patienten en hun familie. (Together we can prevent pres-sure ulcers! a practical brochure for patients and their relatives). Ministerie van Volksgezondheid en Leefmilieu, (Federal Agency for Public Health Services), 1995; Brussels.

12. Duimel-Peeters IGP, Halfens RJG, Berger MPF, Snoeckx LHEH. The Effects of Massage as a Method to Prevent Pressure Ulcers. A review of 
the literature. Ostomy/Nound Mangament 2005,51(4):70-80.

13. Verpleeghuisartsen NNVA. Tripartiete Multidisciplinaire Richtlinn. Samenwerking en Logistiek rond Decubitus. (Tripartite Multi-Disciplinary Guidelines. Cooperation and Logistics regarding Pressure Ulicers.). Nederlandse Yereniging van Verpleeghuisartsen, (Dutch association of Nursing Home Doctors);2003.

14. NPUAP (1992) Statement on pressure ulcer prevention. AHCPR, Silver Spring, MD, pp. 24.

15. EPUAP (1998) Pressure ulcer prevention guidelines. EPUAP.

16. Bours GJJW. Halfens RJG. Wansink SW. Landelijk prevalentie onder zoek decubitus: resultaten zesde jaarlijkse meting 2003. (Annual Dutch Prevalence Pressure Ulcer Survey: results of the sixth annual survey (2003)). Universiteit Maastricht, Dep. Health Care Studies / Section Nursing Science, 2003.

17. Buss IC, Halfens RJG. Huijer-Abu Saad H. The effectiveness of massage in preventing pressure sores: a literature review. Rehab Nurs 1997:22:229-34.

18. Dyson R. Bed sores: the injuries hospital staff inflict on patients. Nursing Mirror 1987;146:30-2.

19. Buss IC, Halfens RJG, Huijer-Abu Saad H, Kok G. Pressure ulcer prevention in nursing homes: views and beliefs of enrolled nurses and other health care workers. Journal of Clinical Nursing 2004:13:668-676.

20. Kitson A, Harvey $G$, McCormack B. Enabling the implementation of evidence based practice: a conceptual framework. Quality in Health Care 1998;7:149-158.

21. Berwick DM. Disseminating Innovations in Health Care. JAMA 2003:289(15):1969-1975.

22. Lubbers M. EPUAP. Personal communication;2001. 


\section{Chapter 5}

\section{Policy, knowledge and practice of massage to prevent pressure ulcers in relation to the Dutch prevalence rates.}

inge GP Duimel-Peeters, Martin PF Berger, Luc HEH Snoeckx, Ruud JG Halfens

Background: Pressure ulcers form a major painful and costly problem in all health care institutions in the Netherlands. Several actwities have been undertaken to reduce the prevalence- and incidence rates of pressure ulcers. Regarding massage, (inter) national guidelines claim that the use of massage is not effective in pressure uller prevention. Nevertheless, massage is still a widely used tool for the prevention of pressure ulcer development. Previously, we found that nurses" knowledge and practice of massage is still not completely in accordance with the prescribed national guidelines. However, the last decade, there is a positive tendency in the nurses' awaremess of the pressure ulcer prevention guidelines. Aims: We hypothesized that nurses their knowledge regarding massage will be positively related to their practice. Furthermore, we expected an interaction between this knowledge and the guided pressure ulcer policy of their institution. And finally, we wanted to find out whether institutions, the nurses of which still use massage, will have higher pressure ulcer prevalence rates. Methods: For this study, secondary analyses were performed on the data-sets of two studies of 2003 , i.e. the Dutch National Pressure Ulcer Prevalence Survey and the 2003 cross-sectional study on knowledge, beliefs and use of preventive methods for pressure ulcer development among Dutch nurses. We used only data from institutions participating in both studies. Furthermore, datia was aggregated on hospital-lewel, and patient populatlons were standardized by using only those patients at high risk for developing pressure ulcers. Results and conclusion: It can be concluded that neither knowledge nor practice is related to pressure ulcer prevalence rates, and that only 2 out of the 11 quality indicators determining the pressure ulcer policy, showed a slightly positive relation with the registered prevalence rate. However, there was a sound relation between nurses" knowledge and their performed practice. But whether their opinion was to belief in the usefulness of mas. sage or not or whether they perform massage or not, no confirmed indications exist. that any argument whatsoever influences the prevalence rates.

Submitted for publication. 
$P$ ressure ulcers (PU) form a major painful and costly problem in all health care institutions in the Netherlands." Several activities have been undertaken to reduce the prevalence- and incidence rates of pressure ulcers. On the institutional level guidelines were adopted or written, nurses speclalised in pressure ulcer prevention were appointed, and courses about the prevention and treatment of pressure ulcers were introduced. Although nurses and other health care givers use various methods to prevent the development of PU, little is known about the general evidence-based effects of these measures. The methods used in practice do not necessarily correspond to what is theoretically recommended. ${ }^{(25)}$ One of the commonly applied methods is massage. In national as well as international guidelines for the prevention of PU, such as the Dutch guidelines, the guidelines of the U.S. Agency for Health Care Policy and Research / National Pressure Ulcer Advisory Panel, and the European Pressure Ulcer Advisory Panel, massage is described as not being useful. ${ }^{(69)}$

In general, guidelines are detailed and complex, and contain a lot of recommendations. As stated by Berwick ${ }^{(1)}$, it is important to reinvent an innovation such as a guideline, and simplify it to the main recommendations. During the implementation-process however, the question arises whether it is necessary to pay attention to the recommendations concerning the use of non-effective methods.

In this study, it will be investigated if it is desirable to pay additional attention to massage which is considered to be such a non-effective preventive method. Therefore, the relations between institutional rules regarding PU prevention, individual knowledge and performed practices of the murses concerning PU prevention, and PU prevalence rates on institutional level, were investigated. In Figure 1, the model with assumed relations between the different features, i.e. PU-policy, knowledge, practice and prevalence rates is shown. 


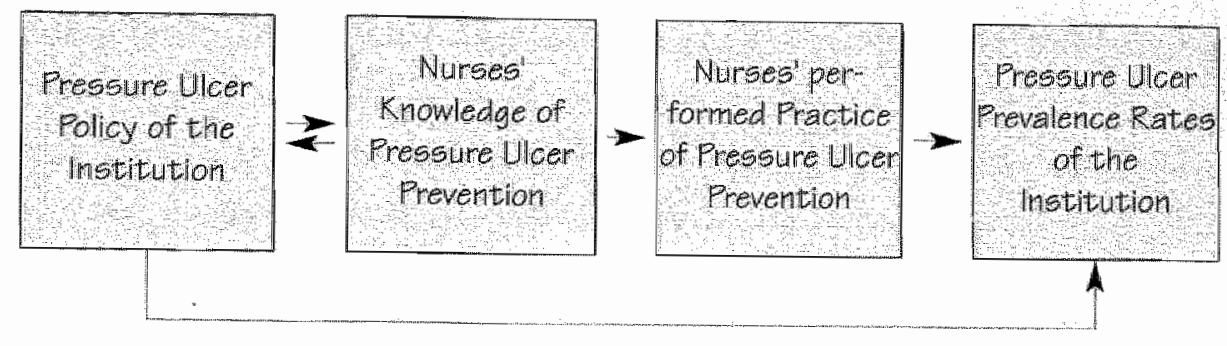

Elgure II Model of the assumed relations between Pu-policy, knowledge, practice and Pu prevalence rates.

It was expected that there exists an interaction between the knowledge of nurses regarding massage and the policy of their institutions. Nurses womking in institutions with a well defined PU-policy were expected to have knowledge regarding massage in accordance with the prescribed national guidelines. Furthermore, it was also hypothesized that nurses' knowledge regarding massage is positively related to their practice. Finally, it was expected that institutions, the nurses of which still use massage wil have higher $P U$ prevalemce rates.

\section{Research questions}

The present study will provide amswers to the following questions:

1. Is the pressure ulcermolicy of an institution, measured by the presence of 11 quality indicators, related to the knowledge (whether or not in accordance with the prescribed national guidelines) of nurses regarding the use of massage to prevert pressure ulcers?

2. Is the murses' knowledge regarding the effectiveness of the use of massage to prevent pressure ulcers related to their actually per.. formed practice?

3. Is nurses" performed practice related to the measured pressure ulcer prevalence rates?

4. Is there a relation between the institutional PU-policy and their prevalence rate? 
For this study, secondary analyses were performed on the data of two studies of 2003, i.e. the Dutch National Pressure Ulcer Prevalence Survey" and the 2003 cross-sectional study on knowledge, beliefs and use of preventive methods for $P U$ development among Dutch nurses.

\section{Study 1: The Dutch Pressure Ulcer Prevalence Survey of 2003}

Each year from 1998 on, a national prevalence registration of PUI is held among Dutch health care institutions. This registration is set up in a way that accurate and reliable data on the scope and the severity of PU with a uniform instrument in different health care settings can be collected. Within each institution, the policy to reduce the Pu prevalence rate relies on the following 11 quality-indicators ${ }^{(11)}$ :

1) the existence of a PU committee; 2) the avallability of written protocol for the prevention of PU; 3) the avalability of a written protocol for the treatment of PU; 4) the presence of a responsible nurse who keeps the protocols for prevention andior treatment of PU up to date, and brings them under the attention of the employees; 5 ) the presence of a person who checks whether guidelines andior protocols are followed or implemented; 6) the central registration of patients prone to PU, as well as; 7 ) of patients with PU; 8 ) management of PU prevention material at the institutional level, as well as; 9) on ward level: 10) the possibility to follow extra training sessions and refresher courses regarding PU prevention and treatment (for the past two years), and 11) the availability of an information brochure for patients and/or family members regarding PU prevention.

For the present study, prevalence rates were calculated at the institutional level. To standardize the patient populations, the rates were calculated only for those patient,s at high risk for developing PU. This risk is measured by the Braden-scale, a tool for evaluating PU risk, conform a score less or equal to 20 . The Braden-score is a sum score of 6 subscales: sensory perception, activity, mobility, moisture, nutrition, friction and shear. Only the $\mathrm{PU}$ developed in the own institution was taken into account in calculating prevalence rates. 


\section{Study 2: The 2003 cross-5ectional study among nurses in the Netherlands}

This study was designed to investigate the knowledge of, the beliefs in, and the use of preventive methods, applied for the PU problem. The survey sample consisted of murses $(N=345)$ who were randomly approached through their affiliation to an institution participating in the 2003-Dutch National Pressure Ulcer Prevalence Survey. Questions were formulated about the knowledge of, and beliefs in preventive methods and the actual use of these methods in practice. For the present study, we focussed on the questions regarding knowledge and actual use of massage as a preventive method for PU.

Regarding the question about knowledge and usefulness of massage in the prevention of PU, response categories were respectively "always", "sometimes', 'never' and 'I don't know'. The categories 'always', 'sometimes', 'never" were used for the question about the actual use of massage in practice. Based on the Dutch national guideline of 2002 the knowledge and practice were judged as right or wrong. The nurses' knowledge regarding the use of massage, and the actual practice of it did not correspond with the prescribed 2002 CBO-guidelines. It is plausible that this gap between theory and practice is partly caused by the 'quality' of the Dutch national guidelines, which are not all evidence-based."

\section{Data-analysis}

For the combination of results of the Dutch PU prevalence survey (study 1) and of the cross-sectional study of 2003 (study 2), we only considered the data from general hospitals. First, frequencies regarding the quality indicators, knowledge and practice, and the mean prevalence scores were calculated. Next, possible relations were inwestigated by using Pearson correlation coefficients (Pearson r). For this analysis the data from study 1 and study 2 were aggregated to the hospital level and then combined in one data-file. By applying aggregation, mean values of the included variables were used. From study 1 , the presence-percentages of the 11 quality indicators, the institutional prevalence rates of $\mathrm{PU}$ and the Braden-scores of the observed patients at high risk for $P U(B S<=20)$ were aggregated at the institutional 
level. From study 2 , the answers on the questions regarding knowledge and practice of massage as a preventive method for PU were aggregated at the institutional level.

4 Results

\section{Study 1: The Dutch Pressure Ulcer Prevalence Survey of 2003}

In total, 43 general hospitals participated, in which 7,956 patients were scored on the presence of PU. The overall prevalence rate for these hospitals was relatively high, i.e. $22.2 \%$. For the present study, we only concentrated upon 20 of these 43 hospitals, because they also participated in the crosssectional study of 2003 . The overall PU prevalence rate in these hospitals (4,335 patients) was $20.4 \%$.

Table 1 shows that in these hospitals the 11 quality indicators were present in percentages ranged between $55 \%$ to $95 \%$. The least represented indicators were "the presence of a person who checks whether guidelines and/or protocols are followed or implemented (testing) (60\%)' and 'management of PU prevention material on ward level (55\%).

\begin{tabular}{|c|c|}
\hline & Presence $(\%)$ \\
\hline Pl committee & 90 (18 hospitals) \\
\hline Prevention protocol & 90 (18 hospitals) \\
\hline Treatment protocol & 95 (19 hospitas) \\
\hline Responsible nurse & $95(19$ hospitals \\
\hline Follow-up implementation guidelines & 60 (12 hospitals) \\
\hline Registration of patients prone to PU & $80(16$ hospitals $)$ \\
\hline Registration of patients having PU & 80 (16 hospitals) \\
\hline Mallagement on institutional level & 95 (19 hospitals) \\
\hline Management on ward level & 55 (11 hospitals) \\
\hline Tiraining possibilities / refresher courses & 90 (18 hospitals) \\
\hline Anformation brochure & 80 (16 hospitals) \\
\hline
\end{tabular}

Table 1 it The presence of quality indicators determining PU-policy, in percentages $(N=20$ general hospitals). 
Study 2: The 2003 cross-sectional study among nurses in the Netherlands

Table 2 shows the accordance between the answers regarding knowledge and practice, as given by 342 nurses ( 3 missings). For instance, when looking in the knowledge category "never useful', in total $33.6 \%$ of the nurses thinks that massage is never effective as a preventive method for PU. Interestingly, a far higher percentage, i.e. $51.2 \%$, claims to never use massage in practice (see practice category "never"). Still $48.8 \%$ of the nurses says they practise massage sometimes or always for preventing PU.

This table also learns that $52.3 \%$ of the nurses gives the same answer on the knowledge and the practice question, which is not very high. Remarkably. some nurses $(7.3 \%)$ indicated that massage is never useful but still use it sometimes.

\begin{tabular}{|c|c|c|c|c|c|c|}
\hline & \multicolumn{5}{|c|}{ Klowledge } \\
\hline & & $\begin{array}{l}\text { Always } \\
\text { useful }\end{array}$ & $\begin{array}{l}\text { Sometimes } \\
\text { useful }\end{array}$ & $\begin{array}{l}\text { Never } \\
\text { useful }\end{array}$ & $\begin{array}{l}\text { Don't } \\
\text { know }\end{array}$ & Total \\
\hline & Always & $7(2.0 \%)$ & $6(1.8 \%)$ & $O(.0 \%)$ & $O(.0 \%)$ & $13(3.8 \%)$ \\
\hline & Sometmes & $43(12.6 \%)$ & $82(24.0 \%)$ & $25(7.3 \%)$ & $4(1.2 \%)$ & $154(45.0 \%)$ \\
\hline & Mever & $14 .(4.1 \%)$ & $57(16.7 \%)$ & $90(26.3 \%)$ & $14(4.1 \%)$ & $175(51.2 \%)$ \\
\hline & Total & $64(18.7 \%)$ & $145(42.4 \%)$ & $115(33.6 \%)$ & $18(5.3 \%)$ & $342(1000 \%)$ \\
\hline
\end{tabular}

Table 2 Cross tabulation of knowledge and practice of 342 nurses regarding mas. sage for preventing PU.

\section{Results from the merged data-files of study 1 and study 2}

Pearson correlation coefficients between the quality indicators on one hand and the answers given on the questions regarding respectively knowledge and practice of massage in preventing PU on the other hand are presented in Table 3 . The knowledge and practice answers of the 345 nurses were aggregated on hospital level. 


\begin{tabular}{|c|c|c|c|c|}
\hline \multirow[b]{2}{*}{ 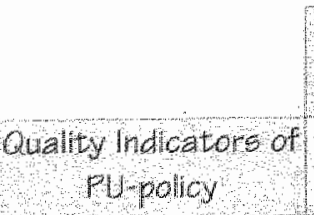 } & \multicolumn{2}{|c|}{$\begin{array}{l}\text { Monedge ahout the use of } \\
\text { massage for praventing PU: }\end{array}$} & \multicolumn{2}{|c|}{$\begin{array}{l}\text { Practice of massage } \\
\text { n preventing PU }\end{array}$} \\
\hline & Pearsont & $5 \lg$ & Rearson & sig. \\
\hline PU committee & -340 & .143 & -.255 & .277 \\
\hline Prevention protocal & $-451^{*}$ & .046 & -.212 & .370 \\
\hline Treatment protocol & -.432 & .057 & -.260 & 268 \\
\hline Responsible nurse & -432 & .057 & -.260 & .268 \\
\hline $\begin{array}{l}\text { Follow-up implemen- } \\
\text { tation guddelines }\end{array}$ & $-.512^{*}$ & .021 & -.418 & .067 \\
\hline $\begin{array}{c}\text { Registration of } \\
\text { patients prone to PU }\end{array}$ & -.325 & .162 & -.323 & .164 \\
\hline $\begin{array}{l}\text { Registration of } \\
\text { patients having PU }\end{array}$ & -.233 & .323 & -.264 & .260 \\
\hline $\begin{array}{l}\text { Management on } \\
\text { institutional level }\end{array}$ & -.432 & .057 & -.260 & .268 \\
\hline $\begin{array}{c}\text { Management on ward } \\
\text { level }\end{array}$ & -.257 & .273 & -.035 & .883 \\
\hline $\begin{array}{c}\text { Training possibilities / } \\
\text { refresher courses }\end{array}$ & -.260 & .269 & -.219 & 353 \\
\hline Information brochure & -275 & 241 & .007 & .975 \\
\hline
\end{tabular}

"Correlation is significant at the 0.05 level (2-tailed)

Bonferonni correction AlphaE $=0.00227$

Iable 3 I Pearson correlations between the qualty indicators determining Pu-policy and: 1) knowledge of the nurses regarding the use of massage as a preventive wethod for PU (let column): and 2 ) the use of massage im practice (right column for PUprovention ( $N=20$ general hospitale).

This table shows that, at the institution level, only the presence of a prevention protocol and the regular follow-up of the guidelines implementation are significantly related to the knowledge nurses have about the usefulness of massage in preventing PJ. There seems to be no significant relation 
between quality indicators and the actually performed practice.

The Pearson $r$ between the nurses' scores on performed practice and knowledge is smaller before aggregation ( $r=437, p<0.01)$ than that aftem aggregation ( $r=599, p=0.01$ ). Due to the aggregation, these differences may occur. That there exists a positive correlated relation between knowledge and practice was in accordance with the expectations.

We also calculated the Pearson correlations between the institutional prevalence rates $(P)$ and their quality indicator scores on one hand and the scores on 'knowledge' and 'practice' on the other hand (Table 4a $+4 b$ ).

\begin{tabular}{|c|c|c|}
\hline & \multicolumn{2}{|c|}{ Overall prevalence rate of the 2,71 high risk patients } \\
\hline & Pearsonr & Sig. \\
\hline PU committee & $-.696^{* *}$ & .001 \\
\hline Prevention protocol & -.308 & .186 \\
\hline Treatment protoco & -.432 & .057 \\
\hline Responsible nurse & -.432 & .057 \\
\hline $\begin{array}{l}\text { Follow-up implementation } \\
\text { guidelines }\end{array}$ & -.386 & .093 \\
\hline $\begin{array}{l}\text { Registration of patients prone } \\
\text { to fll }\end{array}$ & -.120 & .614 \\
\hline $\begin{array}{l}\text { Reglistration of palients } \\
\text { having Pl }\end{array}$ & $-.537^{*}$ & .015 \\
\hline $\begin{array}{c}\text { Mariagement on instilititional } \\
\text { level }\end{array}$ & -.432 & .057 \\
\hline Managemert on ward level & -.394 & .086 \\
\hline $\begin{array}{l}\text { Training possiblities/ } \\
\text { refresher courses }\end{array}$ & -.336 & .148 \\
\hline Information brochure & -.335 & .149 \\
\hline
\end{tabular}

"correlation is significant at the 0.05 level (2-tailed)

** Correlation is significant at the 0.01 level (2-tailed).

Bonferonni correction AlphaE $=0.00454$

Table 4 a I Pearson correlations between the quality indicators determining PU-poli-

$c y$, and the institutional overall prevalence rate $(N=20)$. 
As the data show, both the presence of a PU committee within the institution and the regular registration of patients that develop PU are related to the registered prevalence rate. As shown in Table $4 b$, the nurses' knowledge and practice regarding the use of massage for preventing PU were mot significantly related to the registered prevalence rate.

\begin{tabular}{|c|c|c|}
\hline & \multicolumn{2}{|c|}{ Overall prevalence rate of the 2.171 high-risk patients } \\
\hline & Peansont & sig. \\
\hline Knowedge & .227 & .337 \\
\hline Practlee & .062 & .794 \\
\hline
\end{tabular}

Table 4 | 1 Pearson correlations between nurses' knowledge and practice, and the institutional overall prevalence rate.

\section{Discussion}

This study shows that within 20 general Dutch hospitals in which a thorough survey of knowledge and practice of massage in the prevention of pressure ulcer development was organized, no significant relation could be established between the knowledge and practice of nurses regarding their knowledge and practice of massage and the prevalence rates of pressure ulcers. According to our results, only the nurses' knowledge and their practice are positively correlated, before and after aggregation. Regarding the institutional policy on the preverition and development of pressure ulcers, we found that only 2 out of 11 quality-indicators showed a positive correlation with to the pressure ulcer prevalence rate. Another 2 indicators positively correlated with the existing knowledge of nurses regarding the use of massage in pressure ulcer prevention.

Before answering the formulated research questions in more detail, it should be emphasized that the presence of quality indicators among the investigated hospitals only ranged between minor linits (Table 2). This probably affected the calculated correlation coefficlents. Furthermore, it is 
important to be aware of the ecological fallacy. These results indicates the stand of affairs regarding the relations between PU-policy, knowledge, practice and prevalence rates for patients of Dutch general hospitals at high risk for PU. Due to the use of Pearson's r no causal conclusions can be drawn. Through the used selection-process of the nurses participating in the 2003 cross-sectional study, selection-bias can possibly influence results and hamper generalisation. They were all employed in an institution participating at the annual prevalence survey.

The large differences between the percentages of knowledge and practice in the always- and never category (Table 2) confirm the existing discrepancy between theory and practice as mentioned before. The difference can also partly be explained by the increased workload over the years and/or the tendency to give social-desirable answers.

That nurses" knowledge and practice correlate positively is in accordance with our expectations. However, as a Pearson rof 60 it is not a very high, the association between nurses' beliefs and practices can not be considered to be very strong. This was already visible in Table 1. Other factors, besides knowledge, are apparently of influence on nurses' practice. As mentioned earlier, workload, for instance, can influence actual performances on the work floor.

Furthermore, knowledge and practice do not seem to be related to the registered prevalence rates. In other words, it does not seem to matter if massage is applied in practice or not. This confirms the findings of the study based on the previous randomized controlled trial by Duimel et al."

The presence of a pressure ulcer policy within an institution seems to be related to registered knowledge of the nurses and institutional prevalence rates. The presence of a pressure ulcer committee is positively correlated with the registered prevalence rates, but we must keep in mind that almost all hospitals had such a committee. Therefore, no definite conclusions regarding causality can be drawn. It seems plausible to argument that the presence of a PU committee may affect nurses" knowledge, but this knowledge may inversely also promote the introduction of a pressure litcer committee and/or its actions taken.

In our study, neither knowledge nor practice showed a relation with the 
pressure ulcer prevalence rates. Also a sound relation between knowledge and practice did not seem to influence the prevalence rates. This seems to indcate that the opinion of nurses about the useruhess of massage in the prewention of pressure ulcers and the application of it in practice is without any consequence for the prevalence of pressure uicers.

\section{Conclusion}

In this study, we focussed on massage; a non-effective prevertive method for pressure ulcers, which is still used in practice although (inter)national guidelines advice against its use. To find out whether knowledge and use of massage could influence the institutional pressure ulcer prevalence rates. this study was performed. It was investigated whether the institutional pressure ulcer policy was also related to prevalence rates and which factors were more related: the individual or the institutional factors.

It can be concluded that neither knowedge nor practice is related to the pressure ulcer prevalence rates, and that only 2 out of the 11 quality-indicators showed a slightly positive relation with the prevalence rate. As expected. there was a sound relation bewween nurses' knowledge and their performed practice. However, whether their opinion was to belief in the usefulness of massage or not or whether they perform massage or not, no confirmed indications exist that any argument whatsoever influences the prevalence rates. Therefore, it seems more important to emphasize on evidence based issues regarding pressure ulcer prevention, such as the prevention of pressure and shear forces and regular change of posttion. Therefore, we recommend to pay more attiention to methods described as useful in (inter) national guidelines during the implementation-process.

\section{Acknowledgements}

We are grateful to dr. Gerrie Bours (Arnual Dutch National Prevalence Survey) and Mirjam Hulsenboom (MSc, RN) (Cross-sectional Study of 2003 ) for making the data regarding prevalence rates, quality indicators and information about use and knowledge of preventive methods for PU available for this study. 


\section{$8 \mid$ References}

1. Bours GJJW. Pressure Ulcers: Prevalence measurements as a tool for improving care [PhD-Thesis]. Maastricht: Universiteit Maastricht; 2003.

2. Buss IC, Halfens RJG. Huyer Abu Saad H, Kok G. Pressure ulcer preven tion in nursing homes: views and beliefs of enrolled nurses and other health care workers. Journal of Clinical Nursing 2004;13:668-676.

3. Buss IC, Halfens RJG. Knowledge of (enrolled) nurses working in Dutch nursing homes about pressure sores prevention: introduction [poster]. In: EPUAP, editor; 2001; Le Mans, France: EPUAP; 2001.

4. Duimel-Peeters 1GP, Hulsenboom MA, Berger MPF, Snoeckx LHEH, Halfens RuG. Massage to prevent pressure ulcers: knowledge, beliefs and practice. A cros5-5ectional study among nurses in the Netherlands, in 1991 and 2003. Accepted by the Journal of Clinical Nursing

5. Halfens RJG. Eggink M. Knowledge, beliefs and use of nursing methods in preventing pressure sores in Dutch hospitals. International Journal of Nursing Studies 1995;32(1):16-26.

6. AHCPR, Research AfHCPa. Pressure ulcers in adults: prediction and prevention

92-0047: U.S. Department of Health and Human Services, Public Health Service, Agency for Health Care Policy and Research; 1992.

7. CBO. Toetsing CBvdi. Richtlijn Decubitus (Guidelines on Pressure Ulcers): Centraal Begeleidingsorgaan voor de Intercollegiale Toetsing (Dutch Institute for Healthcare Improvement); 2002.

8. EPUAP. Pressure ulcer prevention guidelines. In: EPUAP: 1998.

9. NPUAP. Statement on pressure ulcer prevention: AHCPR; 1992.

10. Berwick DM. Disseminating Imnovations in Health Care. JAMA 2003: $289(15): 1969-1975$.

11. Bours GJJW, Halfens RJG, Wansink SW. Landelijk prevalentie onderzoek decubitus: resultaten zesde jaarijkse meting 2003. (Anrsual Dutch Prevalence Pressure Lilcer survey: results of the sixth annual survey (2003)). Universiteit Maastricht, Dep. Health Care Studies, Section 
Nursing Science: 2003.

12. Hulsenboom MA. Decubituspreventie door de jaren heen. Een vergelijking van de kennis en inzet van preventieve maatregelen bij decubitus door verpleegkundigen en verzorgenden. (Prevention of Pressure Ulcers. A comparison of the knowledge and use of preventive methods, through nurses and health care givers, for pressure ulcers.][Master-Thesis]. Maastricht: Universiteit Maastricht; 2004.

13. Lubbers M. EPUAP. Personal communication;200\%.

14. Halfens RJG. Achterberg TV, Bal RM. Validity and reliability of the Braden scale and the influence of other risk factors: a multi-centre prospective. International Journal of Nursing Studies 2000:37(4):313-9.

15. Duimel-Peeters IGP, Halfens RJG, Ambergen AW, Houwing RH, Berger MPF, Snoeckx LHEH. The effectiveness of massage with and without dimethyl sulfoxide in preventing pressure ulcers: A randomized, double blind cross-over trial in patient prone to pressure ulcers. Accepted for publication by: International Journal of Nursing Studies. 


\section{Chapter 6}

\section{The effectiveness of massage with and with- out Dimethyl Sulfoxide in preventing pressure ulcers: A randomized, double blind cross-over trial in patients prone to pressure ulcers}

Inge GP Duimel-Peeters, Halfens RJG, Anton W Ambergen. Ronald H Houwing, Martijn PF Berger, Luc HEH Snoeckx

Introduction: Pressure ulcers (PU) are a great problem in Dutch health care institutions. Several preventive methods are used in practice to prevent PU development. One of them is massage, although massage is dissuaded (according to national and international guidelines) because it could be harmful to underlying tissues. Nevertheless, a survey heid in Dutch hospitals showed that almost all nurses evaluated massage as an effective method. Two other cross-sectional studies stated also that what is used in practice does not necessarily correspond to what is theoretically recommended. Aim: We wanted to evaluate the use of massage as a preventive method for PU and did compare this intervention with a group getting only change of position as a preventive method for PU. Research Question: Does massage with an indifferent cream, and with a DMSO-cream combined with a $30^{\circ}$ change of position, administered each 6 hours, lead to a lower incidence of pressure ulcers compared with getting only change of position? Method: Eight nursing homes participated at the R.C.T. Only high-risk patients who conply with the inclusion criteria were included. Two of the three interventions were randomly assigned at each ward. Each intervention took 4 weeks. Between the two interventions, there was a washout period of 2 weeks. Pressure ulcers will be measured according to the four grading system of the EPUAP. The duration of the massage was standardized by the fingertip unit, as described by Long. Results: The interventions "only change of position", 'massage with an indifferent cream' and 'massage with a DMSO-cream', do not differ significantly. OMSO did not fulfil the expectations based on a literature- and a former done pilot-study.

Accepted for publication by: International Journal of Nursing Studies. 
In addition to being painful for patients, pressure ulcers (PU) are a major and Several methods are used in practice to prevent pressure ulcer development. One of these methods is massage. Although massage is internationally no longer officially recommended as a preventive method, the technique is 5 till practiced in health care. Massage is discouraged because it is thought to cause injuries to the skin. Nevertheless, a recent evaluation study reported that nearly all hospital nurses regarded massage as a very effective method for the prevention of pressure ulcers, which is a reason for them to continue this intervention. The same conclusion was drawn from interviews with healthcare workers in nursing homes. ${ }^{(3.9)}$

Quantitative research into the effects of massage has been scarce and limited.(i) In an extensive survey, our research group recently found that the number of studies on this topic was very limited and that the existing studles were of minor methodological quality. (")i) Therefore, further research on the effectiveness of massage, using statistically proven, quantitative data is clearly needed.

A confounding factor in studies on massage is the influence of concomitant position changes during the massage treatment. For instance, Defloor (ia) found that changing patients' position every two hours resulted in a $14.3 \%$ incidence of pressure ulcer injuries, whereas changing positions every three hours led to significantly more pressure ulcers, viz., in $24.1 \%$ of the patients. A combination of changing patients" position every 6 hours and having them lie on a poly-urethane mattress reduced the incidence rate to $15.9 \%$. In the control group, which received the usual preventive methods applied at the institution (not including position changes), $20 \%$ of the patients developed pressure ulcer injuries. Although most official guidelines recommend regularly changing patient.5' position (every 2 - 4 hours), it is known that this does not happen as regularly as necessary. ${ }^{(15.4)}$

The interest in the problem of pressure ulcers is obvious from the increasing application of new insights into the pathophysiological basis of the development of pressure ulcers. For instance, studies with laboratory animals have 
demonstrated that pressure ulcers develop as a result of recurrent ischemia-reperfusion events, in which toxic axygen-deriwed free radicals are produced. An argument supporting this hypothesis is provided by the finding that oral administration of antioxidants cam be effective in preventing the occurrence of pressure ulcers. ${ }^{\text {ra } 20)}$ instead of oral administration locally administered antioxidants could have the same beneficial effects. Dimethyl sulfoxide (DMSO) is a potent scavenger of radicals - especially of the very toxic hydroxyl radical - which penetrates the skin very well. In concentrations below $50 \%$ the product is not toxic. A pilot-study in patients at high risk of pressure ulcers showed that massaging with a DMSO-containing cream leads to a decrease in pressure ulcer occurrence among these patients. ${ }^{(22)}$

The present study intended to assess the effects of massage, including scavenging of oxygen-free radicals, and position changes. Interventions consisting of "massaging with an indifferent cream combined with position changes' were compared with "massaging with a DMSO-cream combined with position changes' and with 'only position changes" only.

The following research questions were therefore formulated: (1) Does massaging with an indifferent cream combined with $30^{\circ}$ position changes aldminm istered at 6-hour intervals to a group of pressure ullcer-prone patients lead to a lower incidence of pressure ulcers compared to a group getting only $30^{\circ}$ position changes' administered in a time-interval of 6 hours?: (2) Does massaging with a "DMSO-cream" combined with $30^{\circ}$ position changes' administered at 6-hours intervals to a group of pressure ulcer-prone patients lead to a lower incidence of pressure ulcers compared to a group getting only $30^{*}$ position changes" administered in a time-interval of 6 hours?; (3) Does massaging with a 'DMSO-cream' combined with $30^{\circ}$ position changes' administered at 6-hours intervals to a group of pressure ulcer-prone patients lead to a lower incidence of pressure ulcers compared to massaging with an indifferent cream combined with $30^{\circ}$ position changes administered in a timeinterval of 6 hours? 
21 Methods

\section{Design}

The study was designed as a randomized, double-blind cross-over trial, in which patients of eight Dutch nursing homes who complied with the inclusioncriteria consecutively received two of the three interventions with a two-week wash-out period. The nursing homes were comparable in terms of guided pressure ulcer policy. Only patients in nursing homes were asked to participate because they have the highest prevalence rates of pressure ulcers in the Netherlands and the population is rather stable over a long time. ${ }^{(23.24)}$ Two treatment periods of four weeks each were used because a four-week observation period has frequently be recommended in pressure ulcer research. ${ }^{25.27)}$

\section{Patients}

Inclusion-criteria were the following: (1) the intervention had to mean no drawback to the patient, (2) the patient had to have a light skin colour, (3) the patient had to reside at a long-stay ward of a nursing home for more than two months, (4) the patient had to rest on an anti-pressure ulcer mattress (i.e. poly-urethane mattress or equivalent), (5) the patient or his/her legally representative had to be willing and able to sign the informed consent form; and (6) the patient had to be at high risk of developing pressure ulcers according to the Braden scale using a cut-off point of 20 .

Exclusion-criteria were: (1) the patient was already being treated with massage for another medical indication (and it was not possible to end this treatment), (2) the palient was to undergo surgery in the nearby future or had undergone surgery less than two weeks ago, (3) pressure ulcers were already present at the coccyx, heels or ankles (the only places that were massaged in this research), (4) the patient was expected to have short length of stay or (5) a short life expectancy ( $<10$ months).

\section{Interventions}

in order to prevent information bias due to errors in performing the assigned intervention from one patient to another, and to decrease the work- 
load and time to be invested by the executive healthcare workers, only two of the three interventions were randomly assigned to each ward (by throwing up dice), and not at patient-level.

The three interventions were:

1. A 2-to 3-minute massage of the coccyx, both heels and ankles with an indifferent cream, combined with a $30^{\circ}$ position change. This procedure was repeated every 6 hours for 4 weeks (Treatment A).

2. A2-to 3-minute massage of the coccyx, both heels and ankles with a 'DMSO-cream' (see below), combined with a $30^{\circ}$ position change. This procedure was repeated every 6 hours for 4 weeks (Treatment B).

3. Only $30^{\circ}$ position change, repeated every 6 hours for 4 weeks (Treatment C).

The decision to change patients' position every 6 hours and the precondition of anti-PU mattresses being used were based on the resulting reduced workload for the executive healthcare workers. For ethical reasons we did not include a control group of patients not receiving any treatment. Because national guidelines encourage regular position changes, it would not be appropriate to do the opposite of what is nationally recommended. Therefore, we regarded group $C$ as the control group of our study.

To prevent possible carry-over effects, the first four-week treatment period was followed by a two week wash-out period before the next intervention was started. Cremor vaselini cetomacrogolis FNA was used as the indifferent cream. This version of Vaseline is spread more easily and protects the skin of elderly people against dehydration. The DMSO-cream consisted of the same cream with an additional $5 \%$ dimethyl sulfoxide added. Patients were massaged at the coccyx, the heels and the ankles as Bours et al. have reported that these three skin areas are responsible for the highest prevalence rates in Dutch health care institutions. ${ }^{232}$. To decrease the workload of the participating healthcare workers, other areas at risk such as elbows, hipbones, and knees were not included. Massage was performed while wearing a hand glove, making soft circular movements. The duration of the massage was standardized, as was the amount of cream to be used. The amount was standardized using the fingertip unit (FTU), as described by Long ${ }^{\text {PM }}$ One FTU 
is the amount of cream spread over the length of the last metatarsal of the forefinger, i.e. about $0.5 \mathrm{~g}$ and $0.45 \mathrm{~g}$ for men and women, respectively. This covers 300 and $250 \mathrm{~cm}^{2}$ of skin, respectively. Before the start of the trial, one patient was massaged by the same nurse with the indifferent cream for 1 week, exactly as it was to be done during the experimental period. At the beginning and end of this week, the amount of cream used was weighed and

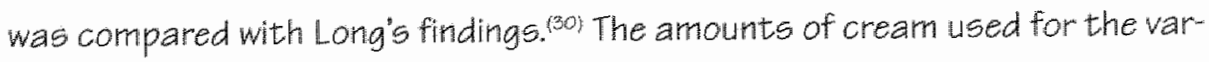
lous body parts were 2 FTUs for the coccyx, 1 FTU for the heel, and 0.5 FTU for each ankle (medialis and lateralis).

One week before the start of the trial, each participating ward was informed about the theoretical background of the study. the work to be expected and the correct way to perform the interventions. The $30^{\circ}$ position change can be performed by a single nurse using pillows (semi-fowler position). This instruction was orally and visually explained to the nurses. ${ }^{31}$

\section{Instruments}

The Braden scale is one of the best-known and most widely used tools for evaluating pressure ulcer risk with proven validity and reliability for risk assessment. ${ }^{29252)}$ The scale consists of 6 subscales reflecting determinants of pressure (sensory perception, activity, and mobility) and factors influencing tissue tolerance (moisture, nutrition, and friction and shear). ${ }^{(39)}$ Possible scores range from 6 to 23. This scale was used as an inclusion criterion (a score $<=20$ meaning the person is at risk of pressure licers). Halfens et al ${ }^{(3)}$ used a cut-off point of 20 and reported a sensitivity of $73 \%$ and a specificity of $70 \%$.

The presence of pressure ulcers was evaluated with the help of the fourgrade system of the European Pressure Ulcer Advisory Panel (Table 1) using a transparent disk. ${ }^{3345)}$ Because of the reversibility of grade 1 ulcers, these ulcers were only recorded as pressure ulcers if they were still present after 4 hours and if two external observers confirmed the nurses conclusion of grade I. When pressure ulcers did occur, the body location, but not the patient was excluded from the research. 
Table 1 I Grading System of Pressure Ulcerg ${ }^{(35)}$

\section{Grade Description}

I Non-blanchable discoloration of intact skin;

II Partial-thickness skin loss involving epidermis, andlor blister or shallow ulcer without undermining of adjacent tissue;

III Full-thickness skin lass involving damage or necrosis of the epidermis andior dermis not extending to underlying bone, tendon or joint;

IV Full-thickness skin loss involving damage or necrosis of the epidermis and/or dermis extending to underlying bone, tendon or joint.

A transparent disk ${ }^{(34)}$ with a diameter of $6.5 \mathrm{~cm}$ was used to assess local redness. This involved first releasing the pressure on the body part, for example by changing the patients' position. If the local redness persisted after 10 minutes, when pushing the convex lens against the skin, the grade 1 pressure ulcer was confirmed.

The presence of pressure ulcers and their grade according to the system shown in Table 1 were used as an outcome measurement.

\section{Distribution of the patient sample}

Two treatment periods of four weeks each were distinguished, separated by a two-week wash-out period. Table 2 shows the frequencles of the distribution of the population for the two periods.

Table 2 I Frequency table for the two treatment periods.

$\begin{array}{llll} & \text { Period 1 } & \text { Perlod 2 } & \text { Total } \\ \begin{array}{l}\text { Massaging with the indifferent } \\ \text { cream (Treatment A) }\end{array} & 32(40.5 \%) & 27(34.2 \%) & 59 \\ \begin{array}{l}\text { Massaging with the DMSO-cream } \\ \text { (Treatment B) }\end{array} & 29(36.7 \%) & 26(32.9 \%) & 55 \\ \begin{array}{l}\text { Onlly position change } \\ \text { (Treatment C) }\end{array} & 18(22.8 \%) & 21(26.6 \%) & 39 \\ \text { Total } & 79(100 \%) & 74(93.7 \%) & \\ \text { Missing } & & 5(6.3 \%) & \end{array}$


In total, 59 patients received massage with the indifferent cream, 55 patients were massaged with the DMSO-cream and 39 patients underwent only position changes.

Treatments were administered in six different orders (Table 3). Each ward was assigned at random to one of these treatment orders, so that each ward used a different treatment scheme during the second period than during the first period.

Table 3 I Distribution of the patients over the various treatment orders.

\begin{tabular}{c|c|c} 
Period 1 & Period 2 & Total Patients \\
Treatment A & Treatment B & 20 \\
Treatment B & Treatment C & 12 \\
Treatment A & Treatment C & 9 \\
Treatment B & Treatment A & 16 \\
Treatment C & Treatment B & 6 \\
Treatment C & Treatment A & 11 \\
Treatment C & Not participated in treatment B & Sub-total: 74 \\
Treatment A & Not participated in treatment C & 1 \\
Treatment B & Not participated in treatment A & 3 \\
& & Missing: 5
\end{tabular}

\section{Data processing}

The he athcare workers who applied the treatments at the participating institutions signed the patients" personal journal after each treatment. When pressure ulcers were identified, they were classifled by recording the grade and date of confirmation in the same joumal. Every two days, the trial leader and an independent registered nurse visited the wards, consulted the Joumals and the healthcare worker responsible for the treatment, and verified the existence of pressure ulcers for each individual patient.

\section{Analysis}

Differences in characteristics between patients in the various treatment groups were tested for each period with Chi-square tests for categorical 
data and t tests for continuous data. Mann-Whithey and Kruskal-Wallis tests were used because of non-nomality of some variables. In order to obtain a preliminary overview of the influence of the three treatments on the outcome variable, frequency tables were constructed for each treatment period. Furthermore, because of the dichotomous outcome variable (PU development or no PU development), logistic regression was used to examine the results of each treatment in terms of pressure ulcer prevention.

Logistic regression was performed within each period. Dummy variables were introduced for the treatment received in each period, in such as way that treatment $C$ was always coded as the control group. To correct for possible confounding variables, we added several covariates (together and $5 e$ parately) that are assumed to be correlated with PU: length, weight, body mass index (BVII), length of stay on the ward (in months), age, sex, incontinence level, type of pressure-relieving cushions used and use of other preventive methods. Non-significant covariates were removed using backward deletion. Finally, Kaplan-Meier curves were constructed to obtain a clearer representation of the survival prognosis for each treatment.

\section{3 | Results}

\section{Sample}

A total of 79 patients, residents of eight Dutch nursing homes, were eligible for the study. Fifty-five patients $(69.6 \%)$ were female. The mean age was $81.3(50=9.76)$, with a range of 45 to 97 . There were no significant differences in patient characteristics for the different comparisons. The characteristics of the patients are shown in Table 4, which presents separate values for each treatment period. 


\begin{tabular}{|c|c|c|c|c|c|}
\hline Characterlstics & Periad 1 & Perlod 2 & Characteristics & Period 1 & Period 2 \\
\hline Age & & & Incontinence & & \\
\hline Mean & 81.43 & 81.62 & Not incontiment & $5.1 \%$ & $4.1 \%$ \\
\hline 50 & 9.76 & 9.60 & Totally ircontinent & $57.0 \%$ & $59.5 \%$ \\
\hline Medlan & 83 & 82.50 & $\begin{array}{c}\text { Sometimes incont- } \\
\text { nent }\end{array}$ & $29.1 \%$ & $27.0 \%$ \\
\hline Range & $45-97$ & $45-97$ & $\begin{array}{l}\text { Only incontinemt } \\
\text { for unine }\end{array}$ & $7.5 \%$ & $8.1 \%$ \\
\hline & & & Missing & $1.3 \%$ & $1.3 \%$ \\
\hline Gender & & & & & \\
\hline Female & \multirow{2}{*}{\multicolumn{2}{|c|}{$55=69.6 \% 52=70.3 \%$}} & & & \\
\hline Length (In cm) & & & $\begin{array}{l}\text { Type of cushion in } \\
\text { seat/wheelchair }\end{array}$ & & \\
\hline Mean & 166.50 & 166.58 & No cushion & $48.1 \%$ & $48.6 \%$ \\
\hline SD & 8.71 & 8.63 & Gel cushion & $3.8 \%$ & $4.1 \%$ \\
\hline Median & 168 & 168 & Air cushilon & $13.9 \%$ & $14.9 \%$ \\
\hline Range & $140-180$ & $140-180$ & Blister cushion & $2.5 \%$ & $2.7 \%$ \\
\hline Weight (in kg) & & & Foam cushion & $20.3 \%$ & $18.9 \%$ \\
\hline Mean & 61.18 & 60.83 & Vessel cushion & $3.8 \%$ & $4.1 \%$ \\
\hline SD & $\$ 4.41$ & 14.63 & Other & $6.3 \%$ & $5.4 \%$ \\
\hline Median & 61.25 & 61 & Missing & $1.3 \%$ & $1.3 \%$ \\
\hline Range & $25-95$ & $25-95$ & & & \\
\hline Body Mass Index & & & Other preventions & & \\
\hline Mean & 21.80 & 21.60 & No other prevention & $72.2 \%$ & $71.6 \%$ \\
\hline SD & 4.91 & 4.85 & Heel protection & $7.6 \%$ & $8.1 \%$ \\
\hline Median & 21.15 & 20.90 & $\begin{array}{l}\text { Solt pillow under the } \\
\text { coccyx }\end{array}$ & $2.5 \%$ & $2.7 \%$ \\
\hline Range & $11-35$ & $11-35$ & Catheter & $6.3 \%$ & $6.8 \%$ \\
\hline & & & $\begin{array}{l}\text { Restingwith } \\
\text { heels free }\end{array}$ & $5.1 \%$ & $5.4 \%$ \\
\hline $\begin{array}{l}\text { Length of stay on the } \\
\text { wards (in months) }\end{array}$ & & & $\begin{array}{c}\text { Other or combina- } \\
\text { tions }\end{array}$ & $5.1 \%$ & $4.1 \%$ \\
\hline Mean & 47.90 & 47.51 & Missing & $1.2 \%$ & $1.3 \%$ \\
\hline SD & 31.41 & 30.60 & & & \\
\hline Median & 40 & 40 & & & \\
\hline Range & $7-144$ & $7-144$ & & & \\
\hline
\end{tabular}

Table 4 Characteristics of the sample, including residents of 8 nursing homes $(N-79)$ 
The patient characteristics we assessed also included incontinence, as several earlier prospective observational studies of pressure ulcer incidence also included incontinence as a risk factor. ${ }^{30.40}$ in addition, knowing that a patient is incontinent should make the observer take extra care to distinguish between incontinence injuries and pressure ulcers.

\section{Differences between periods}

Table 5 shows the PU incidence rates, by grade, for the two treatment periods. In general, grade I accounted for $38.5 \%$ of the incidence rates for treatment period 1 , and for $6.3 \%$ of the incidence rates for treatment period 2. Patients with pressure ulcers were rated as at high risk according to the Braden scale, and we used a cut-off point of 20.

\begin{tabular}{|c|c|c|c|c|c|c|}
\hline & $\begin{array}{c}\text { Grade } \\
1\end{array}$ & $\begin{array}{c}\text { Grade } \\
\text { II }\end{array}$ & Grade & $\begin{array}{c}\text { Grade } \\
\text { IV }\end{array}$ & Total & $\begin{array}{c}\text { PU development } \\
\text { by week }\end{array}$ \\
\hline Treatment period 1 & $38.5 \%$ & $10.3 \%$ & $0 \%$ & $0 \%$ & $\begin{array}{c}48.8 \% \\
(38 / 78)^{*}\end{array}$ & $\begin{array}{l}\text { Week 1: } 24.4 \% \\
\text { Week 2: } 14.4 \% \\
\text { Week 3: } 8.6 \% \\
\text { Week 4: } 1.4 \%\end{array}$ \\
\hline Treatment period 2 & $6.3 \%$ & $4.7 \%$ & $0 \%$ & $\% \%$ & $\begin{array}{c}11 \% \\
(7 / 64)^{* * 4}\end{array}$ & $\begin{array}{l}\text { Week 1: } 6.3 \% \\
\text { Week 2: } 3.1 \% \\
\text { Week 3: } 0 \% \\
\text { Week 4: } 1.6 \%\end{array}$ \\
\hline
\end{tabular}

"1 missing score for PU-develapment

***10 missing scores for PU-development and/or grade recording

Table 5 I incidence of fu by grade, by treatment period and by week. in percentages.

Thirty-eight patients $(48.8 \%)$ developed pressure ulcers in treatment period 1. Most of the pressure ulcers developed in week 1 of both periods. Of those 19 patients (24.4\%) who developed PU in week 1 of treatment period 1. 
3 were receiving treatment $A, 15$ were receiving treatment $B$, and 1 was receiving treatment $C$. In treatment period 2,7 (11\%) patients developed pressure ulcers. Of the $4(6.3 \%)$ patients who developed PU in week 1,1 was receiving treatment $A, 2$ were receiving treatment $B$ and 1 was receiving treatment $C$.

In both periods, most pressure ulcers developed at the coccyx (17.7\% and 6.3\%, respectively). The combination of "coccyx and heel' PU also occurred frequerty (10.1\%) in treatment period 1, followed by PU at the heel only (i.e. 8.9\%). Pressure ulcers at the "ankle", and combinations of "coccyx and ankle' or 'heel and ankle' were not common in period 1 ( $2.5 \%$ for each of the three). In period 2. PU at the "heel' and combinations of "heel and ankle" occurred in $1.3 \%$ of the patients. Most patients developed their PU in week 1 of both periods, with a strong decreasing tendency for ewery following week.

\section{Differences between treatments}

The frequency of PU in each period is presented in Tables 6 and 7 . In both periods, Chi-square-tests were not significant, resulting in p-values of 0.189 and 0.726 . However, there was an obvious difference between the periods in the occurrence of pressure ulcers. During the first period, the effect of massaging with the indifferent cream was almost the opposite of massaging with DMSO-cream (Table 6), whereas during the second period, it seemed not to be matter which treatment was used to prevent pressure ulcers (Table 7).

\begin{tabular}{c|c|c|c} 
& $\begin{array}{c}\text { No Pressure } \\
\text { Ulcers }\end{array}$ & Pressure Ulcers & Total \\
Only position change & $11(61 . \%)$ & $7(38.9 \%)$ & $18(100 \%)$ \\
$\begin{array}{c}\text { Massaging with the } \\
\text { indifferent cream }\end{array}$ & $18(58.1 \%)$ & $13(41.9 \%)$ & $31(100 \%)$ \\
$\begin{array}{c}\text { Massaging with the } \\
\text { DMSO-cream }\end{array}$ & $11(37.9 \%)$ & $18(62.1 \%)$ & $29(100 \%)$ \\
\hline Total & $40(51.3 \%)$ & $38(48.7 \%)$ & $78 \%(100 \%)$ \\
\end{tabular}

Chi-square $=3.336 ; p=0.189$

"I missing value for the variable development of PU-scores"

Table 6 Frequency table for treatment period 1 and development of pressure ulcers. 


\begin{tabular}{c|c|c|c} 
& $\begin{array}{c}\text { No Pressure } \\
\text { Ulcers }\end{array}$ & Pressure Ulcers & Total \\
\hline $\begin{array}{c}\text { Only position change } \\
\text { Massaging with the } \\
\text { indifferent cream } \\
\text { Massaging with the } \\
\text { DN50-cream }\end{array}$ & $16(94.1 \%)$ & $1(5.9 \%)$ & $17(100 \%)$ \\
\hline Total & $22(88.0 \%)$ & $3(12.0 \%)$ & $25(100 \%)$ \\
\hline
\end{tabular}

Chi-square $=.639$ ( 3 cells have expected count less than 5 ): $p=0.726$

* 5 missing values for people not participating in treatment period 2 , and another 10 missing values for the variable 'development of PU-scores'

Table $7 \mid$ Frequency table for treatment period 2 and development of pressure ulcers.

It can be concluded that the addition of DMSO to the indifferent cream had no effect on the occurrence of pressure ulcers.

\section{Logistic Regression}

Separate logistic regressions were performed for the two treatment periods. For the received treatment separately, dummy variables were included whereby the change of position group without massage was coded as the control group.

\section{Treatment period 1}

There was no treatment effect in period 1 . The p-value for the group massaged with the indifferent cream was 834 (OR=1.135), while that for the DMSO-group was $126(O R=2.571)$ (see Table 8).

\begin{tabular}{l|c|c|c|c|c|c} 
& B & S.E. & Wald & Df & p-value & OR \\
$\begin{array}{l}\text { Massaging with an indifferent } \\
\text { cream (Treatment A) }\end{array}$ & .127 & .605 & .044 & 1 & .834 & 1.135 \\
$\begin{array}{l}\text { Massaging with DMSO-cream } \\
\text { (Treatment B) }\end{array}$ & .944 & .617 & 2.346 & 1 & .126 & 2.571 \\
Constant & -.452 & .483 & .874 & 1 & .350 & .636
\end{tabular}

Table 8 I Final model of the logistic regression for treatment period t. 
The final model resulted in the following equation:

$\operatorname{Ln}($ odds $)=-0.452+0.127 \times$ Treatment $A+0.944 \times$ Treatment $B$

The covariates did not significantly affect the Ln(adds) of pressure ulcers.

Treatment period 2

In the second period, we found puvalues of 441 (OR=2.526) and 516 $(O R=2.182)$ for treatment $A$ and treatment $B$ respectively (see Table 9 ). There were more missing values in this period than in the first period.

\begin{tabular}{|c|c|c|c|c|c|c|}
\hline & $B$ & S.E. & Wald & Df & p-value & $O R$ \\
\hline $\begin{array}{l}\text { Massaging with an indifferent } \\
\text { cream (Treatment A) }\end{array}$ & .927 & 1.204 & .593 & 1 & .441 & 2.526 \\
\hline $\begin{array}{l}\text { Massaging with DMSO-cream } \\
\text { (Treatment B) }\end{array}$ & .780 & 1.201 & .422 & 1 & .516 & 2.182 \\
\hline Constant & -2.773 & 1.031 & 7.235 & 1 & .007 & .063 \\
\hline
\end{tabular}

Table 9 I Final model of the logigtio regression for treatment period 2.

1061

The fimal model for treatment period 2 was:

$\operatorname{Ln}($ odds $)=-2.773+0.927 \times$ Treatment $A+0.780 \times$ Treatment $B$

\section{Kaplan-Meier survival cunves}

Survival analysis can be regarded as a logistic regression analysis including more additional information, meaming that whereas logistic regression analysis uses cumulative incidence rates, survival anallysis uses incidence densitities.

Two plots of Kaplan-Meier survival curves for pressure ulcer occurrences are shown in Figures 1 and 2 for each of the two treatment periods. 


\section{Survival Functions}

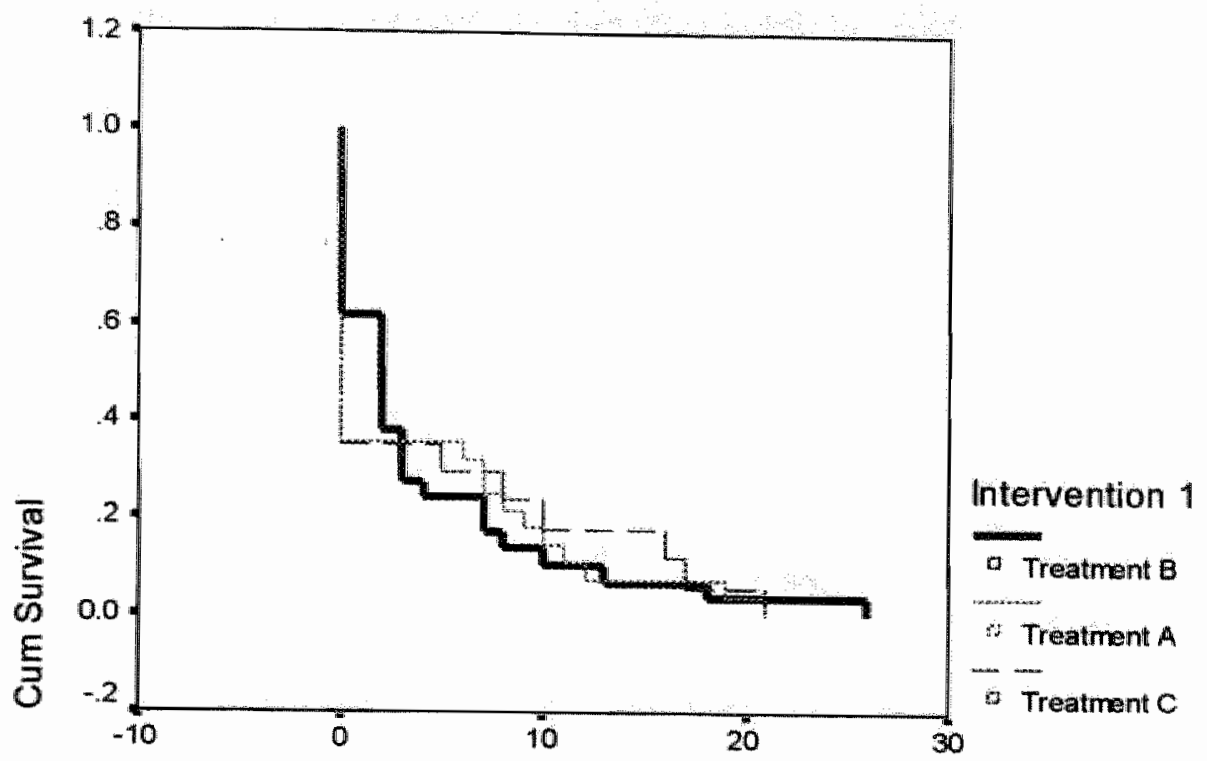

\section{Days before PU occur in treatment period 1}

Figure 1 I $K M$-curve for treatment period 1

Figure 1 shows that massaging with the indifferent cream (treatment $\mathrm{A}$ ) or only changing of positions (treatment C) seemed to result in better pres. sure ulcer-free prognosis than being massaged with the DMSO-cream (treatment B). As times goes on, the dashed and bold curves appear to grow further apart (until day 18), suggesting that the beneficial effects of only changing position relative to massaging with a DMSO-cream increase as treatment conthued for a longer period. However, beyond day 18, the three treatments tended to have the same effects. 


\section{Survival Functions}

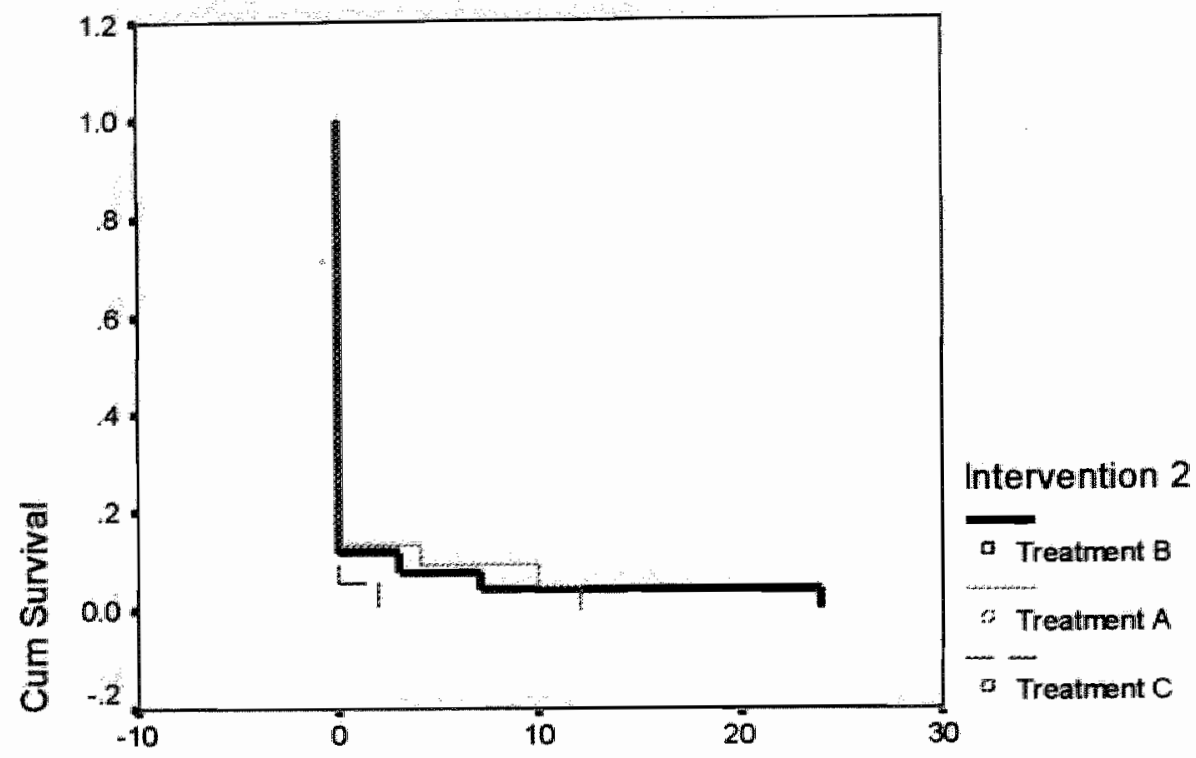

\section{Days before PU occur in treatment period 2}

Figure 2 I KM-curve for treatment period 2

Figure 2 shows that there are minimal step functions because of the relatively small $N$ and the missing values in treatment period 2. But even here, massaging with the indifferent cream (treatment $A$ ) is preferable to the use of DMSO-cream.

\section{I Dischssion}

Pressure ulcers are still a major problem, as is confirmed by our high incidence rates. This study was intended to contribute to the establishment of adequate pressure ulcer prevention by investigating the effects of massage as a preventive method.

We did not find any significant, differences between the three treatments and found no evidence of any positive influence of massaging with a DMSOcontaining cream. Although there were no significant results, we tentatively conclude that position changes alone are to be preferred to massaging the skin areas that are most at risk in high-risk patients. If massage is pre- 
ferred, a simple indifferent cream will suffice. In spite of the hopeful results of an earlier pilot study ${ }^{122}$, our study ald not confirm that the use of DMSO leads to a marked decrease in pressure ulcer development among high-risk patients. We even presume that using a larger study population, which would enlarge the 'negative' effect of the DMSO-cream, could result in (marginally) significant effects. Most of the developed pressure ulcers that developed appeared in the first two weeks, suggesting that habituation after some time decreases the occurrence or development of pressure ulcers. The most common location where pressure ulcers developed was the coccyx, followed by heel and ankle. This outcome is consistent with the assumptions made about the anatomic locations at risk. ${ }^{(4.4 .43)}$

The design irvolved a sample of 79 patients, divided over two treatment periods and three interventions. We preferred two treatment periods rather than three to shorten the trial period and to reduce the workload of the participating nurses and caregivers.

An explanation for the differences between the two treatment periods is hard to find. One possibility is that the motivation of the participants and the accuracy with which the treatments were applied in treatment period 2 was not comparable with that in treatment period 1. There were also more missing values for this second treatment period because some patients and relatives decided to end their participation, and because some of the participating health care workers got tired of applying the treatment as accurately as possible. In addition, the relatively small sample size hampered our analyses. The distribution of the population for each group sometimes became too small when splitting up covariates into several dummy variables. In such cases, we would for instance decide to use "preventive cushions", with response options 'yes/no', rather than splitting the response categories up into all the initial response options initially identified. Selecting on diagnosis or medication would make the amount of participants also smaller, so we thought pragmatically. By randomizing the wards, and so the patients, towards the treatments, we considered the different groups as homogeneous regarding their different features, such as diagnosis or used medications. 
Based on our results, it appears that massage is not as harmless the literature or guidelines sometimes suggest."(it) it is possible that the main effect of massage lies in the accompanying additional position change that accurs with every massage treatment. Since we used no 'real' control group, it must be kept in mind that this study assessed the possible added value of massage to prevent pressure ulcers, rather than the effect of massage on its own. One could also assume that the nurses" hand-contact with the patients and the extra attention this implies affected the patients" psychological well- being. However our study did not investigate this.

The findings of the present study have certain consequences for the daily practice of treating patients at risk of PU. In view of the results, it seems that neither massaging with a DMSO-cream nor massaging with an indifferent cream is to be preferred as a method to reduce the high incidence rates of PU. Indeed, the $48.8 \%$ incidence rate in treatment period 1 is still extremely high, even when we keep in mind that continuous registration easily leads to underestimation of the occurrence of pressure ulcers. Therefore, we recommend that nurses and health care workers follow the national guidelines recommending regular position changes to prevent the development of PU.

\section{Conclusion}

The outcomes of three treatments, viz. "position changes only', 'massaging with an indifferent cream' and 'massaging with a DMSO-cream' did not differ significantly. There is no reason to assume that massaging with an indifferent cream is harmful to underlying tissues when it is provided gently with small circular movements. However, it would be desirable to take some tissue biopsies before and after massage treatment of patients prone to PU, in order to confirm the conclusion that massage is not harmful to skin and underlying tissues. However, from a deontological perspective, it is questionable whether or not such approach can be justified.

On the other hand, since no benefits of massage were found either, it seems that only position changes, are an effective method to prevent pressure ulcers on condition that they are applied regularly (every 2-4 hours), as 
indeed recommended in the Dutch national guidelines. ${ }^{(5,4.44)}$ DMSO did not fulfil the expectations raised by the literature and an earlier pilot-study. If massaging, combined with position changes, is preferred, the use of an indifferent cream can be advised but one should be aware of the fact that massaging has nothing to do with PU prevention. It would be interesting to repeat this study in a larger population sample and with every patient undergoing all three treatments to improve statistical analyses. For now we conclude that regular position changes can be effective as a method to prevent pressure ulcers, and that massaging with an indifferent cream, whem applied in the right way as described above, will do no harm nor produce benefits.

\section{Acknowledgements}

We are grateful to the patients, their relatives and participating staff at the following Dutch nursing homes: Valkenheim, Valkenburg; Panhuys, Hulsberg; De Dormig/Heerenveld, Landgraaf/Kerkrade; Huize De Berg. Heerlen; Hamboskliniek, Kerkrade; Lückerheidekliniek, Kerkrade; De Riethorst, Geertruidenberg. Special thanks are due to the pharmacists at the University Hospital Maastricht, Maastricht; and especially to Mrs. Leonne Heltzel (RN) who acted as a second independent observer.

\section{References}

1. Bours, GJuW, Halfens, RJG, Huijer Abu-Saad, H, Grol, RTP M. Prevalence, prevention and treatment of pressure ulcers: A descriptive study in 89 institutions in the Netherlands. Research in Nursing and Health 2002;25(2):99-110.

2. Severens, JL, Habraken, JM, Frederiks, CMA. Kosten van decubitus in Nederland: een inventarisatie op basis van expert-opinion. WCS Nieuws = Woundcare Consultant Society Nieuws 2000;16(2):20-25.

3. Severens, JL, Habraken, JM, Duivenwoorden, S, Frederiks, CMA. The cost of illness of pressure ulcers in the Netherlands. Advances in Skin \& Wound Care 2002;15(2):72-77. 
4. AHCPR, Research, AfHCPa. Pressure ulcers in adults: prediction and pre wention Clinical Practice Guideline no. 3.U.S. Department of Health and Human Services, Public Health Service, Agency for Health Care Policy and Research;1992 May 1992. Report No:92-0047.

5. CBO, Toetsing. CBudl. (1992). Revision of pressure ulcer consensus [ln Dutch]. Utrecht: Centraal Begeleidingsorgaan voor de Intercollegiale Toetsing.

6. EPUAP. (1998b). Pressure ulcer prevention guidelines. Retrieved 20-112002 .

7. Halfens, RJG, Eggink, M. Knowledge, beliefs and use of nursing methods in preventing pressure sores in Dutch hospitals. intermational Journal of Nursing Studies 1995:32(1):16-26.

8. Buss, IC, Halfens, RJG. Knowledge of (enrolled) rurses working in Dutch nursing homes about pressure sores prevention : introduction [poster]. Paper presented at the Education: experiences we can share: 5th European Pressure Ulcer Advisory Panel open meeting: 2001 September 27-29, Le Mans, France.

9. Buss, IC, Halfens, RJG, Huyer Abu Saad, $H_{*} \&$ Kok, $G$. Pressure ulcer prevertition in mursing homes: views and beliefs of enrolled nurses and other health care workers. Journal of Clinical Nursing 2004; $13.668-676$.

10. Buss, 1C, Halfens, RJG, Huijer-Abu Saad, H. The effectiveness of massage in preventing pressure sores: a literature review. Rehab Nurs 1997:22(5): 229-234.

11. Duimelpeeters, IGP. Halfens, RJG, Berger, MPF, Snoeckx, LHEH. The Effects of Massage as a Method to Prevent Pressure Ulcers. A review of the literature. Ostomy/Wound Management $2005: 51(4): 70-80$

12. Defloor, T. Pressure relief and change of position in the prevention of pressure ulcers. [In Dutch]. (PhD-Thesis) Gent:Uniwersiteit Gent:2000.

13. Belgischewerkgroep-Kwaliteitszorg-Preventie-en-Behandeling-Decubitus. (1995). Samen kummen wij doorligwonden voorkomen! : een bondige em praktische brochure voor patiënten en hun familie (brochure) [ln Dutch]. [Brussei]: Ministerie van Volksgezondheid en Leefmilieu. 
14. CBO, Toetsing, CBval. (2002). Richtlijh Decubitus. Utrecht: Centraal Begeleidingsorgaan voor de Intercollegiale Toetsing.

15. Houwing, RH, Overgoor, M. Pressure-induced skin lesions in pigs: reperfusion injury and the effects of vitamin E. J Wound Care $2000 ; 9(1): 36-40$

16. Braden, Bu, Bergstrom, N. A conceptual scheme for the study of the etiology of pressure sores. Rehabilitation Nursing 1987;12(1): 8-12.

17. Brewer Jr. RD, Leal, JF, Mihaldzic, N. Preliminary observations on the effect of oral zinc sulfate on the healing of decubitus ulcers. Proceedings of the Annual Clinical Spinal Cord Injury Conference, 15 (November 7 1966):93-96.

18. Cerrato, PL. How diet helps the skin fight pressure sores. Rehabilitation Nursing 1986:67-68.

19. Frias Soriano, L, Lage Vazquez, M A, Maristani, C P, Xandri Graupera, $J \mathrm{M}$, Wouters-Wesseling, W, Wagenaar, L. The effectiveness of oral nutritional supplementation in the healing of pressure ulcers. Journal of Wound Care 2004;13(8):319-322.

20. Malone. AM. Supplemental zinc in wound healing: is it beneficial? Nutrition in Clinical Practice 2000;15(5):253-256.

21. Duimel-Peeters, IGP, Houwing, RH, Teunissen, CP, Berger, MPF, Snoeckx, LHEH, Halfens, RJG. A systematic review of the efficacy of topical skin application of Dimethyl Sulfoxide on wound healing and as an antiinflammatory drug. WOUNDS (A Compendium of Clinical Research and Practice) 2003:15(11):361-370.

22. Van Rossum, JP. (1997). Behandeling en preventie van decubitus met dimethulsulfoxide - verslag van een pilotstudie. (Treatment and prevention of pressure sores with Dimethyl Sulphoxide - a report of a pilotstudy).

23. Bours, GJJW, Halfens, RJG, de Winter, A. Landelijk prevalentie onderzoek decubitus: uitgebreide resultaten eerste jaarlijkse meting 1998 [In Dutch]. Maastricht: Universiteit Maastricht, Dep. Health Care Studies/Section Nursing Science, Maastricht. 
24. Bours, GJJW, Halfens, RJG, Joosten, CMC. Landelijk prevalentie onder zoek decubitus: uitgebreide resultaten tweede jaarljkse meting 1999 [in Dutch].(2e herziene dr.). Maastricht.: Universiteit Maastricht, Dep. Health Care Studies/Section Nursing Science, Maastricht.

25. Bergstrom, N, Braden, B. Kemp, M, Champagne, M, Ruby, E. Multi-site study of incidence of pressure ulcers and the relationship between risk level, demographic characteristics, diagnoses, and prescription of preventive interventions. Journal of the American Geriatrics Society $1996 ; 44(1): 22-30$.

26. Chan, WH, Chow, KW, French, P, Lail, YS, \& Tse, LK. Which pressure sore risk calculator? a study of the effectiveness of the Norton scale in Hong Kong. International Journal of Nursing Studies 1997;34(2):165-169.

27. Langemo, DK, Olson, B, Hunter, S, Hanson, D, Burd, C. CathcartSilberberg. T. Incidence and prediction of pressure ulcers in five patient care settings. Decubitus 1991;4(3):25-36.

28. Bours, GJJW, Halfens, RJG, Joosten, CMC. Landelijk prevalentie onder zoek decubitus: resultaten derde jaarlijkse meting 2000 [In Dutch]. (2e herziene druk). Maastricht: Universiteit Maastricht, Dep. Health Care Studies/Section Nursing Science, Maastricht.

29. Bours, GJJW, Halfens, RJG, Lubbers, M, Haalboom, JRE. The development of a national registration form to measure the prevalence of pressure ulcers in the Netherlands. Ostomy Wound Management 1999:45(11):28-40.

30. Long, C. (1993, 26 march 1993). The correct use of topical steroids. Paper presented at the Current topics in dermatology. Northern Europe, London.

31. Bus5, IC, Halfens, RJG. (1995). Vragenlijst Decubitus Onderzoek. (Questionnaire on Pressure Ulcer Research.). Maastricht: Rijksuniversiteit Limburg.

32. Halfens, RJG, Achterberg. TV, Ball, RM. Validity and reliability of the Braden scale and the influence of other risk factors: a multi-centre prospective. International Journal of Nursing Studies 2000;37(4):313-319. 
33. Bergstrom, N. Braden, BJ, Laguzza, A, Holman, V. The Braden scale for predicting pressure sore risk. Nursing Research 1987;36(4):205-210.

34. Derre, B. De evolutie van beginnende decubitus bij patiënten op een Intensieve Zorgeenheid. Verpleegkunde 1999;14(4):246-247.

35. EPUAP. (1998a, September 20-22). Four-grade system. Paper present ed at the European Pressure Ulcer Advisory Panel, Oxford, UK.

36. Allman. RM. Pressure ulcer prevalence, incidence, risk factors. and impact. Clinics in Geriatric Medicine 1997:13(3);421-436.

37. Bergstrom, N, Braden, B. A prospective study of pressure sore risk among institutionalized elderly. Jourmal of the American Geriatrics Society 1992;40:747-775.

38. Berlowitz, DR, Wilking, SVB. Risk factors for pressure sores: a comparison of cross-sectional and cohort-derived data. Journal of the American Geriatrics Society 1989;37(11):1043-1050.

39. Brandeis, GH, Hossain, M, Morris, JN, Lipsitz, LA. A Iongitudinal study of risk factors associated with the formation of pressure ulcers in nursing homes. Journal of the American Geriatrics Society 1994:42(4):388-393.

40. Schnelle, JF, Adamson, GM, Cruise, PA, Samarrai, NA, Sarbaugh, FC, Uman, $G$, et al. Skin disorders and moisture in incontinent nursing home residents: intervention implications. Journal of the American Geriatrics Society 1997:45(10):1182-1188.

41. Bours, GJJW, Halfens, RJG. Wansink, SW. Landelijk prevalentie onder zoek decubitus: resultaten zesde jaarlijkse meting 2003 [In Dutch]. (1e druk). Maastricht: Universiteit Maastricht, Dep. Health Care Studies/Section Nursing Science, Maastricht.

42. Langemo, DK, Hanson, D. Cathcart-Silberberg. T, Hunter, $S$.

Prevalence of pressure ulcers in five patient care settings. Journal of Enterostomal Therapy 1990:17(5):187-192.

43. Weiler, $P G$, \& Kecskes, D. Pressure sores in nursing home patient5. Aging 1990:2(3):267-275.

44.CBO, Toetsing, CBvdl. (1985). Consensus preventie van decubitus. (Consensus on pressure ulcer prevention.). Utrecht: Centraal Begeleidingsorgaan voor de Intercollegiale Toetsing. 


\section{Chapter 7}

General Discussion | 


\section{$1 \mid$ Introduction}

M

assage is often used to prevent the development of pressure ulcers. In this dissertation, the beliefs in, the knowledge of and the use of massage and its effectiveness in preventing pressure ulcers have been investigated. In this last chapter the main findings are briefly summarized, and some theoretical and methodological reflections are presented. Finally, implications for practice and recommendations for future research will be forwarded.

\section{I Main Findings}

This thesis shows that massage techniques are generally well defined and described in the literature. Only one of them, i.e. effleurage, fits for the treatment of pressure ulcers because this technique seems to be hammless for tissues underlying the skin (chapter 2). In the daily practice, opposite opinions exist regarding the effectiveness of massage for the prevention of pressure ulcer development. This is exemplified by the difference between the content of existing guidelines and the actwally performed practice of nurses and other health care givers (chapters 4 and 5 ).

One of the main conclusions of this thesis is that massage (as effleurage) does not prevent the development of pressure ulcers (chapter 6). On the other hand, massage (i.e. effleurage) does not have the expected negative effects on the humain skin and pressure ulcer development as assumed by some authors. ${ }^{(i-3)}$ Aside from that, in contrast with what is generally believed on the effectiveness of dimethyl sulfoxide (DMSO) ${ }^{(4,5)}$, this compound did not have the expected beneficial effects in patients prone to pressure ulcers (chapter 6). Our randomized clinical trial revealed that the outcome of patients treated with regular change of position on an aniti-pressure ulcer mattress was not worse or better than that of patients that were treated with massage on the body parts prone to pressure ulcer development. Thus, to reduce cost and time investment in the daily care of nursing homes, it is preferable to treat patients prone to pressure ulcers with regular changes of positions without additional massage. As such, our findings support the Dutch national guidelines for the prevention of pressure ulcers. ${ }^{(6)}$ 


\section{I Theoretical reflections}

\section{Relevance of the study}

The relevance of this thesis lies in clarifying the existing discrepancy between theory and practice regarding the use of massage as a preventive method for pressure ulcers in the Netherlands. Our detailed analysis of literature studies was inspired by the observation that massage is still widely practised to prevent the development of pressure ulcers, even when the guidelines of the European Pressure Ulcer Advisory Panel and other (inter)national guidelines no longer recommend massage as a preventive treatment for pressure ulcers. (7.1) In fact, massage is dissuaded because it is considered to cause injuries of the skin. Nevertheless, research shows that almost all Dutch hospital nurses evaluated the use of massage as a very effective method. "12-14) Objective reports of the possible beneficial effects of massage as a preventive method for pressure ulcers are scarce. The reported results in those studies are often not statistically significant. while the overall methodological quality is questionable. ${ }^{(15.16)}$ To facilitate the implementation of a (part of a) guideline it is important that it is based on sound evidence. Until now, only 5 percent of the current Dutch guidelines are evidencebased. (17) Our epidemiological research was initiated to improve the understanding of the effects of massage, all or not in combination with DMSO, on pressure ulcer development.

Theories regarding the development of pressure ulcers

As described in chapter 1, two theories regarding the development of pressure ulcers have been postulated, i.e. the top-down and the bottom-up theo$y$. The present thesis does not provide conclusive evidence to accept or reject one of the prevailing hypotheses regarding the development of pressure ulcers. Elucidating the aetiology of pressure ulcers is still an important domain for research. Until now, both theories are supported by scientific evidence. Irrespective of which theory is most acceptable, we are convinced that the scoring of the presence of pressure ulcers, as presented in chapter 6 , was well performed. Indeed, if pressure ulcers are initiated in the epidermis as the top-down hypothesis claims - our measurement of irreversible redness 
of the skin seemed to be appropriate. On the other hand, when pressure ulcers first arise in the deep muscle layers covering bony prominences, as hypothesized in the bottom-up theory, it could be argued that these ulcers do not develop fast enough towards the skin surface, i.e. within 4 weeks, so that pressure ulcers can not be measured adequately through palpation and obserwation of the skin surface. Because it has been shown that ulcers, arising in the deep muscle layers and covering bony prominences, develop at a faster rate than superficlal ulcers and yield more extensive ulceration, we assume that in this case the measurement of pressure ulcers through visible observation and palpation will also be satisfactory. ${ }^{\text {(ng) }}$ It can not be excluded however, in case ulcers would have developed in deep layers in a late phase of the investigation, that we scored some patients as false negative.

\section{Methodological Refiections and Results}

4.1 I Regarding the performed randomized contwolled trial (chapter 6)

Design

For the study as presented in chapter 6 , a randomized controlled trial (R.C.T.) conducted as a double-blind cross-over design was applied. In this design three different interventions were defined and randomized. To prevent information-bias, arising from errors in performing the assigned intervention from one patient to another, and to decrease the workload in time for the executive nurses and health care givers, only two of the three interventions were randomly assigned at each ward, and not at patient-level. The patients received these two interventions in a consecutive way with a wash-out period of two weeks between the two interventions.

It is clear that a complete statistical analysis could only have been performed if all patients were subjected to all three interventions. In that case however, we suspected that most nursing homes would not lend their cooperation because of the relatively high workload and time-investment. To avoid this situation, we anticipated with an adapted design.

The choice for changing the patients" position each 6 hours, instead of the more commonly prescribed 2-3 hours, was based on information from 
Defioor. ${ }^{(3)}$ In this study it was found that the incidence rate of pressure ulcers was lower when the patients' position was changed each 6 hours in combination with a poly-urethane mattress (15.9\%) then when the position was changed each 3 hours (24.1\%). Another advantage of a change of position each 6 hours was the decreased workload for the nurses.

\section{Inclusion criteria}

For our patient study we defined 6 inclusion-criteria of which the demand of a Braden-score of 20 orlower was repeatedly tested. Even when the study was started, patients were scored again the first day of every new week to measure their risk for developing pressure ulcers. While other studies often recommend the use of a cut-off point of 18 , we preferred a cut-off point of 20. Using this cut-off point, Halfens and colleague ${ }^{20)}$ reported a sensitivity of $73 \%$ and a specificity of $70 \%$ for scoring pressure-ulcer risk successfully. The advice for a cut-off point of 18 is mainly based on research whereby the criterion "the existence of pressure ulcers versus no pressure ulcers" as predictive outcome value has been used, and not "the risk of pressure ulcers development". The Braden scale is a summated rating scale consisting of six subscales, i.e. sensory perception, activity, mobility, moisture, nutrition, friction and shear. Five of the six subscales are rated from 1 (least favorable) to 4 (most favorable) except friction and shear, which is rated from 1 to 3 . Nursing personnel familiar to the patient can perform the rating in less than 1 minute. ${ }^{(21)}$ To avoid the problem of low inter-rater reliability, we insisted that the same nurse always performed the rating on the same patient.

\section{Data analysis of the R.C.T.}

Initially we intended a multi-level analysis because of measurements at the level institutions, wards and patients. However, because not all patients received all three interventions, multi-level analysis would hamper a proper data-analysis. Concerning the possibility of regression analysis, only logistic regression was applicable to our results because of the dichotomous outcome variable. Due to the relatively small sample size, categorical variables sometimes had to be categorized to fulfil the assumption of at least 5 observations at each cell. 
Differences between the two intervention periods in the R.C.T.

A logical explanation for the differences between the two intervention periods is difficult to provide. It is possible that the motivation of the participants and the accuracy by which the interventions were performed during the second intervention period were less than in the first intervention period. This can partly be explained by patients andior relatives that wanted to quit the study, and to some participating health care workers who got tired of performing the intervention as precisely as possible. Therefore, it is questionable if the reliability of the values is as high in the second intervention period as in the first one.

Generalizability of the R.C.T. - results

In spite of a sample population of 79 nursing home residents and some contradictory results in both intervention periods, we can conclude that the results of this study can be generalized to a general nursing home population at high risk for pressure ulcers. Because of our strict formulated inclusioncriteria, one coull assume that external valldity would be affected. However; these inclusion-criteria were strictly defined in order to include only patients at high risk for pressure ulcers and to ensure that underlying pressure ulcers were not yet developed in other institutions, and would not be a criterion causing any selection-bias. To increase the uniformity of pressure ulcer polioy and management between the different nursing homes, we deliberately selected nursing homes which are members of the same pressure ulcer commission (South-East Limburg). However, we were forced to look further than South-East Limburg in order to enlarge the population sample. Therefore, one additional nursing home from outside this region was approached.

Oum conclusion that massage does not have an additional beneficial effect in the prevention of pressure ulcers is probably valid for other institutions. As such, it provides support for the Dutch national guidelines, in so far that regular change of position is advisable while massage is not. However, we could not present evidence that' massage is definitely hamnless. It should be pointed out that our conclusion that effleurages are not harmful is only based on a literature study and on visual observations on the skin, and not on observations in underlying tissues. 


\section{2 l Regarding the cross-sectional studies of 1991 and 2003 (chapters 4 and 5 )}

\section{Ecological fallacy}

Regarding the cross-5ectional study of the 1991 survey and both crosssectional studies of 2003, we can make comparable remarks. Because of the large samples sizes of individuals participating in these 3 studies and because of the formulated research questions, a cross-sectional design would normally be most appropriate. However, in this way causal relationships can not be investigated, because correlations can only indicate possible relations. As such, only common sense can further indicate in which direction these possible relations may develop. For the two cross-sectional studies of 2003 ( see chapter 5), the two data-files were merged after aggregation at the institutional level. This was achieved by using the mean values of all included variables. After aggregation, some correlation coefficients differed from the coefficients before aggregation, although this did not cause a change in statistical outcome. Nevertheless, this should be kept in mind when interpreting aggregated results.

\section{Generalizability}

In chapter 4, we analyzed the results obtained in general and acadernic hospitals. This contrasts with the two cross-sectional studies of 2003 as presented in chapter 5 , in which only general hospitals were taken into account. Therefore, the outcome of these studies can only be generalized to general hospitals-settings. The choice for hospitals instead of nursing homes was based upon the large number of potential participants which are employed in hospitals, and because of the recurrence of the same hospitals in the different studies. Thus, a comparison between different studies was possible.

5 I implications for practice

At first, the results of our study support the Dutch CBO-guidelines regarding the use of massage in relation to pressure ulcers. This means that 
also in our opinion massage can not be considered to be an effective preventive method for the prevention of pressure ulcer development. We would like to stress the following practical recommendations:

\section{Do not use massage to prevent pressure ulcers}

We were unable to find evidence for preventive effects of massage regarding pressure ulcer development but did also not find conclusive evidence in support for rejection of massage, as the CBO-guidelines suggests. Indeed, no indications were found that massage (i.e. effleurage) was harmful to the skin and its underlying tissues.

This been said, there still exists a gap between theory and practice (chapter 4 and 5). In spite of the different motives to reject massage as a preventive method, we do hope that this research supports the implementation of the CBO-guidelines regarding the use of massage in pressure ulcer prevention.

\section{Use regular change of position}

As already described in (inter)national literature, supported by statistically significant evidence, and as recommended by several (inter)national guidelines, regular change of body position can help to prevent pressure ulcer development. In combination with this action, we recommend the use of an anti-pressure ulcer mattress. If an anti-pressure ulcer mattress is not available, a patient should be turned over more often than each 6 hours.

\section{Do not UGe DMSO as a preventive method}

In spite of the results of our literature review (chapter 3 ) and a previously performed pilot study ${ }^{(5)}$, DMSO, topically applicated in concentrations up to $5 \%$, did not show any beneficial effect at all. Therefore, we do not recommend the use of this compound in the prevention of pressure ulcer development.

6 Recommendations for future research

The fact that massage (effleurage) does not seem to harm the skin can motivate institutions to continue the practice of massage. For instance, 
massage can be experienced by the patient as a welcome theathent, and as such it could promote the patients" psychological feeling of well-being. However, one should be well aware of the fact that this has nothing to do with pressure ulcer prevention. In terms of nursing home management; we would advise to quit the practice of massage for the prevention of pressure ulcers, because it has no evident beneficial effects, it saves time, and there can also be a cost-benefit effect for management-teams.

Our results on the effects of DMSO are contradictory to those found by Van Rossum in a pilot study on patients prone to pressure ulcers. ${ }^{\text {s. }}$ Since it has been shown in earlier studies that DMSO adequately penetrates the skin and ever reaches the subcellular level - the site at which $\mathrm{HH}^{-}$-radicals are generated - it can be excluded that insufficient penetration is the cause of the inefficiency of DMSO (see chapter 3 ). Therefore, we reject DMSO as a compound first choice when considering free radicals as important mediators of the devellopment of pressure ulcers. To elucidate the possible beneficial effects of free radical scavengers, other compounds could be evaluated in detail. Besides ischemia-reperfusion mediated damage on which we focussed, the influence of cell deformation is another interesting pathway for future investigations in the domain of pressure ulcer-aetiology and prevention. The extent to which cells can deform is determined among others, by the strength of proteins belonging to the extra-cellular matrix. Products that may beneficially affect this extra-cellular matrix should be tested as well. In this context, the importance of fundamental research to understand more of the aetiology of pressure ulcers can not be accentuated enough.

Furthermore, it would be easier to analyse collected data from a R.C.T. in which all patients are subjected to all interventions so that more profoumd (multi-level) analysis can be performed. Randomization at the patient level instead of at the ward level would be an option, but in our opinion not to be advised because it increases the risk of information-bias. A larger population sample can be desirable because it would strengthen any conclusion regard. ing the absence, cq. presence of beneficial DMSO effects. Aside from that, a daily visit of the wards would be helpful in motivating. stimulating and controlling the nurses and participating health care givers. From this point of 
view, instead of a larger population a small population like 10 per group could also be advantageous. Randomization could be performed at the patientlevel, fewer participants should be needed to perform the intervention and it would be better controllable.

in order to further contribute to the evaluation of the bottom-up theory, it would be desirable to take some tissue biopsies before and after treatment of patients prone to pressure ulcers, in order to confirm the conclusion that massage (effleurage) is mot harmful to skin and underlying tissues. However, from a deontological perspective, it is questionable whether or not such approach can be justified. Last but not least, studies focussing on preventive methods to decrease pressure ulcer development are surely important for making the existing guidelines more evidence-based and to simplify the implementation-processes of only the effective proven guidelines. Intervention studies, focussing on curative aspects regarding pressure ulcer treatment should also get more attention. Based on the outcomes from fundamental research, these intervention studies must be set up to make nursing practice more evidence-based and to get more insight in the aetiology and pathogenesis of pressure ulcers.

7 Rererences

1. Braden BJ. Bryant R. Innovations to prevent and treat pressure ulcers. Geriatric Nursing 1990:182-6.

2. Dyson R. Bed sores: the injuries hospital staff inflict on patients. Nursing Mirror 1978:146(24):30-2.

3. Olson B. Effects of massage for prevention of pressure ulcers. Decubitus.1989;2(4):32-7.

4. Duimel-Peeters IGP. Houwing RH, Teunissen CP. Berger MPF, Snoeckx LHEH, Halfens RJG. A systematic review of the efficacy of topical skin application of Dimethyl Sulfoxide on wound healing and as an antiinflammatory drug. WOUNDS (A Compendium of Clinical Research and Practice) $2003 ; 15(11): 361-70$. 
5. Van Rossum JP. Behandeling en preventie van decubitus met dimethyl sufoxide - verslag van een pillotstudie. (Treatment and prevention of pressure sores with Dimethyl Sulphoxide - a report of a pilot-study). In; 1997.

6. CBO, Toetsing CBvdl. Richtlijn Decubitus (Guidelines on Pressure Ulcers): Centraal Begeleidingsorgaan voor de Intercolleglale Toetsing (Dutch Institute for Healthcare Improvement); 2002.

7. AHCPR, Research AfHCPa. Pressure ulcers in adults: prediction and prevention. Clinical Practice Guideline no. 3: U.S. Department of Health and Human Services, Public Health Service, Agency for Health Care Policy and Research: 1992 May 1992. Report No: 92-0047.

8. Belgische-Werkgroep-Kwaliteitszorg-Preventie-en-BehandelingDecubitus. Samen kunnen wij doorligwonden voorkomen! : een bondige en praktische brochure voor patiënten en hun familie. brochure. [Brussel]: Ministerie van Volksgezondheid en Leefmilleu; [1995].

9. CBO, Toetsing CBvdl. Richtlijn Decubitus. Utrecht: Centraal - Begeleidingsorgaan voor de intercollegiale Toetsing; 2002.

10. EPUAP. Pressure ulcer prevention guidelines. In: EPUAP; 1998.

11. NPUAP. Statement on pressure ulcer prevention. Silver Spring, MD: AHCPR: 1992.

12. Buss IC, Halfens RJG. Knowledge of (enrolled) nurses working in Dutch nursing homes about pressure sores prevention : introduction [poster]. In: EPUAP, editor. Education : experiences we carl share: 5th European Pressure Ulcer Advisory Panel open meeting; 2001 September 27-29, 2001: Le Mans, France: EPUAP: 2001.

13. Buss IC, Halfens RJG. Huyer Abu Saad H, Kok G. Pressure ullcer prevention in nursing homes: views and beliefs of enrolled nurses and other health care workers. Journal of Clinical Nursing 2004:13:668-676.

14. Halfens RJG. Eggink M. Knowledge, beliefs and use of nursing methods in preventing pressure sores in Dutch hospitals. International Journal of Nursing Studies 1995;32(1):16-26.

15. Buss IC, Halfens RJG, Huijer-Abu Saad $H$. The effectiveness of massage in preventing pressure sores: a literature review. Rehab Nurs 1997;22(5):229-34,242. 
16. Duimel-Peeters IGP, Halfens RJG. Berger MPF, Snoeckx LHEH. The effects of massage as a method to prevent pressure ulcers. A review of the literature. Ostomy/Wound Management 2005;51(4):70-80.

17. Lubbers M. EPUAP. (Personal Communication): 2001.

18. Bouten CV, Oomens CW, Baaijens FP, Bader DL. The etiology of pressure ulcers: skin deep or muscle bound? [commentary]. Archives of Physical Medicine and Rehabilitation 2003;84(4):616-9.

19. Defloor T. Pressure relief and change of position in the prevention of pressure ulcers. [In Dutch]. Gent: Universiteit Gent; 2000.

20. Halfens RJG, Achterberg TV, Bal RM. Validity and reliability of the Braden scale and the influence of other risk factors: a multi-centre prospective. International Journal of Nursing Studies 2000;37(4): 313-9.

21. Bergstrom N, Braden B, Kemp $M$, Champagne $M$, Ruby E. Predicting pressure ulcer risk : a multisite study of the predictive validity of the Braden scale. Nursing Research 1998:47(5):261-9. 
esearch findings published in the literature as well as practical experien-
ce show that there is great confusion over the question whether massage prevents the development of pressure ulcers (PU). Some nurses are still fully convinced of the value of massaging to prevent pressure ulcers, motwithstanding conflicting national and international guidelines. Others completely reject this method. Regardless of published guidelines, both groups consider their opimions to be based on arguments from the research literature.

This thesis reports on a reseanch project that objectively examined the effect of massage on the prevalence of pressure ulcers. The project first examined the effects of massaging in general, after which it focused on massaw ging as a method to prevent pressure ulcers. In addition, a prior study had raised the expectation that massaging with a cream containing a radical scavenger might be more effective than massaging with an indifferent cream. Hence, we studied the available literature on the effects of 5 uch a radical scawenger, dimethyl sulfoxide (DMSO), before starting an experiment to empirically compare massaging with and without DMSO.

We combined the findings of two studies assessing the knowledge of beliefs about and actual use of massage to prevent pressure ulcers among. nurses, dating from 1991 and 2003, and compared their results with the Dutch guidelines prevalent at the time. The outcome reconfirmed the existing discrepancy between theory and practice.

The Introduction to this thesis (Chapter 1) discusses the background to the problem of pressure ulcers, by outlining the physiology and blood supply system in healthy skin and the aetlology and pathogenesis of pressure ulcers. Since there is as yet no consensus on the latter, several competing explanatory models of the origin and development of pressure ulcers are dis. cussed.

Since we wanted to use one unequivocal definition of pressure ulcers, we adopted the definition proposed by the European Pressure Ulcer Advisory Panel (EPUAP), and the corresponding system of 4 degrees of severity. Chapter 1 also explains why the research centred on the effect of massage to 
prevent pressure ulcers, and why the use of DMSO was investigated. The chapter ends by stating the overall goals of the research project reported on in this thesis and surveys the content of the thesis.

Chapter 2 describes a literature study into massage in general and its use as a potential method to prevent pressure ulcers in particular. The art of massage is an ancient one: texts dating from before $2000 \mathrm{BC}$ refer to the healing effect of rubbing a person's body with one's hands. Much research has been done and published into the mechanical, psychological and relaxing effects of massage. This chapter surveys the various manual massaging techniques, with their indications and contraindications. It then goes on to discuss the clinical and physical aspects of pressure ulcers, the physiology of the skin, the extrinsic and intrinsic factors affecting the development of pressure ulcers and the relations between 'time' and 'pressure' ard their effects on the interstitial fluid compartments. Knowledge of massage techniques and of the causes and development of pressure ulcers has led to the conclusion that the only massage technique that might be appropriate is effleurage, which imposes minimal strain on the skin and underlying tissues.

Chapter 3 presents the findings of a systematic survey of the literature on the effects of topical application of dimethyl sulfoxide (DMSO) on the skin in terms of wound healing and as an anti-inflammatory agent. Pressure ulcer development involves the formation of free radicals (as indicated, for instance, in the theory of ischemia-reperfusion damage). The most important of these free radicals are the superoxide anion $\left(\mathrm{O}_{2}\right)$, hydrogen peroxide $\left(\mathrm{H}_{2} \mathrm{O}_{2}\right)$ and the rydroxyl radical (OH"). It has been suggested that radical scavengers might slow down the development of pressure ulcers or evem help prevent them, by eliminating harmful radicals. One such radical scavenger, which specifically eliminates the hydroxyl radical, is DMSO. A prior study among a population of nursing home residents at high risk of pressure ulcers had found favourable effects of DMSO on reversing pressure ulcer development. Our literature study tried to identify the potential favourable effect of DMSO on wound healing and inflammatory mechanisms, and the dosages required for such effects. Based on the literature findings, and those of the prior study, we decided that adding 5\% DMSO to an indifferent cream should be 
enough as an active ingredient. This concentration was also assumed to cause no harmful side effects like erythema and itching.

Chapter 4 surveys the existing knowedge among Dutoh nurses about massaging as a potential method to prevent pressure ulcers, as well as their bellefs about favourable effects of massage for this purpose and their actual use of massage to prevent pressure ulcer development. Data sets from two previous cross-sectional studies were compared. The first of these studies dates from 1991 and inwolved interviews with 373 nurses, while the second dates from 2003 and included 529 nurses. We assessed whether there were any differences between these two populations as regards knowledge, beliefs and practice, and whether their knowledge, beliefs and practice corresponded with the guidelines prevalent in each of these periods. The results showed that the nurses in 2003 were "doing better" than those surveyed in 1991. At the same time, it became clear that the official Dutch gui delines were still insufficiently being implemented by nurses.

Chapter 5 discusses the findings in greater detall, by linking the data from the 2003 cross-sectional study to those of another cross-sectional study from the same year, the National Prevalence Study of Pressure ulcers (Bours et al.). All data were analysed at aggregated institutional level (i.e. that of general hospitals), which we hoped would yield information on possible relations between nurses' knowledge, their behaviour in practice and the national guidelines on the one hand, and the actual prevalence data on the other. We also assessed whether an institute's pressure ulcer policy was related to nurses' knowledge and the prevalence of pressure ulcers. As expected, knowledge and practical behaviour among murses were highly correlated. However, neither knowledge nor practical behaviour appeared to be related to actual prevalence data obtained from surveys. These findings partly support those of the study reported on in Chapter 6 . Some of the quality indicators that help determine an institute's pressure ulcer policy do appear to have some impact on the prevalence rates.

Chapter 6 describes the results of a randomised controlled trial we undertook to assess two main questions:

(1) Does massaging with an indifferent cream every six hours, combined with 
repositioning on an anti-PU mattress, have a preventive effect on the development of pressure ulcers among patients at high risk of such ulcers (as indicated by a Braden score of 20 or (ower), compared with a similar group receiving only position changes every six hours?

2) Does massaging with a cream containing DMSO every six hours, in combination with repositioning on an anti-PU mattress, have a preventive effect on the development of pressure ulcers among patients at high risk of such ulcers (as indicated by a Braden score of 20 or lower), compared with a similar group receiving either massage with an indifferent cream combined with repositioning or repositioning alone (both administered every six hours)?

The results of the trial allow the unequivocal conclusion that massaging does not contribute to the prevention of pressure ulcers. On the other hand, they also show that massaging in the form of effleurage does not appear to be harmful, as has often been suggested in the literature. Contrary to our hypothesis, DMSO was found to have an unfavourable effect on pressure ulcer development.

Chapter 7 outlines the main findings of the various studies and presents some methodological and theoretical reflections on these findings. The methodological reflections focus on the RCT design we used, the justification of the Braden scale cut-off point we chose and the generalisability of our RCT results and those of the two combined cross-sectional studies. The theoretical reflections try to establish the social relevance of the studies and briefly outline existing theories on the development of pressure ulcers insofar as they are relevant to the present research. The chapter ends by discussing the implications of our findings for nursing practice and providing recommendations for further research. 


\section{somenvattingl}

1 it de literatuur én in de praktijk blijkt dat er grote verwarring bestaat over een al dan niet preventief effect van massage bij de ontwikkeling van decubitus (drukwonden). Daar waar de ene verpleegkundige, ondanks tegerstrijdige (inter)nationale richtijnen zweert bij massage ter preventie van decubitus, verwerpt de andere het helemaal. Los van de voorgeschreven richtlijnen menen beiden hun mening te kunnen baseren op argumenten aangevoerd vanuit de wetenschappelijke literatuur.

In dit proefschrift wordt het effect van massage op het voorkomen van decubitus onderzocht. Allereerst zijn de effecten vam massage in het algemeen in kaart gebracht, om vervolgens meer specifiek te kijken naar massage als preventieve activiteit bij decubitus. Naar aanleiding van een eerder verricht vaoronderzoek werd bovendien verwacht dat massage met een crème waaraan een radicaal-scavenger (= radicaal-wegvanger) was toegevoegd een meerwaarde zou kunnen hebben. Vandaar dat ook een literatuurstudie is verricht naar de effecten van de radicaal-scavenger dimethyl sulfoxide (DMSO) alvorens een experiment op te zetten waarin massage met én zonder DMSO empirisch getoetst werd.

Twee studies, respectievelijk van 1991 en 2003, die de kennis van-, het geloof in en de toegepaste praktijk van massage in decubituspreventie onder verpleegkundigen onderzachten, werden aan elkaar gekoppeld. Hun uitkomsten werden vergeleken met de geldende CBO-richtijnen. Op basis hiervan werd de bestaande discrepantie tussen theorie en praktijk nogmaals bevestigd.

In de introductie van dit proefschrift (hoofdstuk 1), wordt de achtergrond van het decubitusprobleem besproken. Daartoe wordt de fysiologie en de bloedvoorziening van de gezonde huid geschetst, om vervolgens de etiologie en pathogenese van decubitus toe te lichten. Omdat hierover geen consensus heerst zijn er verschillende verklaringsmodellen woor het ontstaan en de ontwikkeling van decubitus. Deze worden allen beschreven.

Om een eenduidige definitie van decubitus te hanteren is gekozen voor de definitie en het daarbijhorende 4-gradensysteem van het European Pressure Ulcer Advisory Panel (EPUA.P). In hoofdstuk 1 wordt verder toegelicht waarom het effect van massage in relatie tot decubituspreventie het centrale thema 
is in dit proefschrift, en waarom uiteindelijk ook voor het gebruik van dimethyl sulfoxide werd gekozen. Er wordt afgesloten met de beschrijving van het uiteindelijke doel van deze thesis en met een overzicht van de inhoud en opbouw ervan.

Hoofdstuk 2 beschrijft de literatuurstudie naar massage in zijn algemeenheid en meer specifiek naar massage als mogelijk preventief middel voor decubitus. De kunst van het masseren is niet nieuw. In geschriften van vóo 2000 voor Christus wordt er reeds melding gemaakt wan het helende effect van het wrijven met de handen. Er is heel wat onderzoek verricht en gepubliceerd over de mechanische, psychologische en relaxerende effecten van massage. De verschillende manuele technieken van massage zijn in dit hoofdstuk in kaart gebracht, evenals de indicaties en contra-indicaties van deze technieken. vervolgens worden de klinische en fysische aspecten van decubitus besproken, de fysiologie van de huid, de extrinsleke-en intrinsleke factoren van invloed op decubitusontwikkeling, en de relatie tussen 'tijd" en 'druk' en hur effect op de interstitiële voeistofcompartimenten. Op basis van de kennis over massage en de kennis omtrent het ontstaan en de ontwikkeling van decubitus is geconcludeerd dat als massage dient gebruikt te worden, men zich dient te beperken tot de effleurage-techniek teneinde de huid en onderliggende weefsels zo min mogelijk te belasten.

Hoofdstuk 3 beschrijft het systematisch onderzoek van bestaande literatuur rond de effectiviteit van dimethyl sulfoxide (DMSO) op wondheling enerzijds en als anti-inflammatoir middel anderzijds, en dit bij lokale aanbrenging op de huid.

De ontwikkeling van decubitus gaat gepaard met de vorming van vrije radicalen (zie a.a. de theorie van de ischemie-reperfusie schade). De belangrijkste vertegenwoordigers van deze radicalen zijn het superoxide anion $\left(\mathrm{O}_{2}{ }^{-}\right)$, waterstof peroxide $\left(\mathrm{H}_{2} \mathrm{O}_{2}\right)$ en het hydroxyl radicaal $\left(\mathrm{OH}^{\prime}\right)$. De idee bestaat dat radicaal-scavengers de ontwikkeling van decubitus zouden kunnen afrernmen of zelfs kunnen helpen woorkomern via het wegvangen van de schadelijke radicalen. Eén van zulke radicalen-wegvangers, specifiek inwerkend op het hydroxyl radicaal, is DMSO. Een eerder verricht vooronderzoek bij een in een verpleeghuis verblijvende hoog-risico populatie voor decubitus toonde gunstige effecten van DMSO aan op het terugdringen van decubitusontwikkeling. Met deze 
literatuurstudie is nagegaan in welke mate en in welke hoeveeheid DMSO mogelijk een inwloed heeft op wondheling en op ontstekingsmechanismen. Op basis van dit onderzoek en het voorafgaande vooronderzoek is besloten dat 5\% DMSO, toegevoegd aan een indifferente creme, voldoende moest zijn als werkzame substantie. Bovendien zou deze concentratie geen aanleiding geven tot het optreden van schadelike nevenwerkingen zoals roodheid en jeuk.

Hoofdstuk 4 brengt voor de Nederlandse verpleegkundigen de stand van zaken in kaart betreffende hun kennis omtrent mas5age als een al dan niet werkzaam preventief middel voor decubitus, hun geloof in de eventueel heilzame werking van massage als preventief middel en de effectief uitgevoerde praktijk van het masseren wan patiënten ter preventie van decubitusontwikkeling. Van twee cros5-sectionele studies die in het verleden uitgevoerd werden, werden de data-sets gekoppeld. De eerste studie dateert van $1991(373$ ondervraagde verpleegkundigen), de tweede studie van 2003 (529 ondervraagde verpleegkundigen). Er werd enerzijds getoetst op verschillen tussen beide populaties betreffende kennis, geloof en praktijk, en anderzijds op de mate van overeenkomsten met de richtijinen uit de betreffende perioden. De resultaten geven aan dat de verpleegkundigen van 2003 het "beter" doen dan deze van 1991. Desondanks blijt het duidelijk dat de CBO-richtijnen nog steeds niet voldoende zijn doorgedrongen zijn tot op de werkvloer.

Hoofdstuk 5 gaat nog dieper in op dit onderzoek. Hiertoe werd de data van de cross-sectionele studie van 2003 gekoppeld aan de data var een andere cross-sectionele studie uit 2003 , namelijk het Landelijk Prevalentie Onderzoek Decubitus (LPOD) (Bours et al.). Hierbij werden alle gegevens op geaggregeerd instellingsniveau (i.e. algemene ziekenhuizen) geanalyseerd. We hoopten hiermee inzicht te krijgen in het al dan niet bestaan van relatles tussen de kennis van verpleegkundigen, de uitgevoerde praktijk en woorgeschreven CBO-richtlijnen enerzijds en de witeindelijk gemeten prevalentie-cijfers anderzijds. Tevens werd nagegaan of het decubitusbeleid van een instelling samerhing met de kennis wan verpleegkundigen en de gemeten prevalentile van decubitus. Zoals verwacht bleek dat de kennis van- en de toegepaste praktijk door verpleegkundigen sterk met elkaar correleren. Kennis noch praktijk echter lij." ken een verband te tonen met de uiteindelike gemeten prevalentie-cijfers. Een uitkomst die de uiteindelijke resultaten van de studie in hoofdstuk 6 voor een 
stuk zal onderschrijwer. Enkelle kwalteitsindicatoren die mee het decubitusbeleid van een instelling bepalen liken wel enigzins van invloed op het gemeten prevalentieciffer.

Hoofdstuk 6 beschrift de resultaten van onze uitgevoerde R.C.T. (randomized controlled trial) waarin twee hoofdvragen centraal stonden:

1) Heeft massage met een indifferente crème, uitgevoerd om de zes uum in combinatie met wisselligging op een anti-decubitus matras, bij hoog-risico patiënten voor decubitus conform een Braden-score van 20 of lager, een preventief effect op het ontstaan van decubitus, vergeleken met éénzelfde groep die echter enkel wisselligging om de zes uur kreeg toegepast?

2) Heeft massage met een DMSO-bevattende crème, uitgevoerd on de zes uur in combinatie met wisselligging op een anti-decubitus matras, bij hoogrisico patiënten voor decubitus conform een Braden-score van 20 of lager, een preventief effect op het ontstaan van decubitus, vergeleken met énzelfde groep die echter of massage met een indifferente crème gecombineerd met wisselligging kreeg, of enkel wisselligging kreeg (beiden eveneens om de zes uur)?

De gevonden resultaten leiden tot de éénduidige conclusie dat massage niet bijdraggt aan de preventie van decubitus. Evenwel tonen zij ook aan dat massage, uitgevoerd als effleurages, niet schadelijk lijkt te zijn zoals vaak beweerd wordt in de literatuur: In tegenstelling tot de gestelde hypothese bleek DMSO echter een negatieve invloed te hebben op de decubitusontwikkeling.

In hoofdstuk 7 worden de belangrijkste bevindingen van de verschilende studies beschreven en onderworpen aan methodologische en theoretische reflecties. De methodologische reflectie spitst zich o.a. toe op de keuze van het door ons gehanteerde R.C. T.-ontwerp, de verantwoording voor het gekozen afkappunt bij de Braden-schaal, de generaliseerbaarheid van de R.C.T.resultathen en die van de gekoppelde cross-sectionele studieresultaten. De theoretische reflectie wil de maatschappelijke relevantle van de studie aantonen en belicht kort de twee bestaande theoriërn voor de ontwikkeling van decubitus in het kader van ons onderzoek. Als laatste worden de implicaties van deze studie voor de praktijk besproken en worden aanbevelinglen gegeven voor toekomstig wetenschappelijk onderzoek. 


\section{| Dankaan... |}

\section{Promotie Team}

Prof. dr. Martijn Berger

Prof dr. Luo Snoeckx

dr. Ruud Halfens, FEANS

\section{Ondersteunend Team}

Nymike de Jang

Monique Du Moulin

Gerrie Bours

Heidi Breuker

Kris Joosten

\section{Paranimfen}

Het Nederlands-Belgisch collectief:

Leonne Heltzel \& Patricia Stas

\section{Technische Ondersteuning}

Door participerende verpleeg- en

verzorgingshuizen:

Valkenheim, Valkenburg

Panhuys, Hulsberg

De Dormig (en dependances), Landgraaf

Huize De Berg, Heerlen

Hamboskliniek, Kerkrade

Lückerhelidekliniek, Kerkrade

De Riethorst, Geertruidenberg

\section{voor snelle services}

Dhr. Hardy en zilin apothekersteam van het Academisch Ziskenhuis Maastricht

Voor drulfwerken Qharkexpress-hulp

The (Bart en Koen) Adams Family

Ontwerp kaft, lay-out- en PC-hulp

Linda, Hans, Peter en Ruben

\section{Sociale Back-up}

Lode en Natalie (\& Nina en Emma)

Peter en Mara (\& Kiani en Joran)

Mario en Tamara (\& Jonas en Jente)

Jim en Patricia (\& Stef en Emma)

Geert en Katrien (\& Tristan)

Carlo en Sara

Jo en Lieve

Vera, Evi, Linda, Nynke

Fam. Kerkhofs

Wirixstraat-buren

Mijn 'reserve-ouders' Georges en

Bernadine

Mirjam, Maaike en Judith

Afwisselend: Astrid; Sabine en Filippo (\& Joyce en Shauni); Willy, Nelly en Stéphanie, dank voor alle goede zorgen \& oppas woor Berend!

\section{Left-overs}

Ton Ambergen

Michel Renierkens

Katrin Balzer

Jacques Neyens

Karin Deckers

Liliane Rouschop

Marga Doyle

Ronald Houwing

Jan Klerkx

Sjan Schroevers

Betsy Scholz

Hans van Rossum

Jan Meyers

Rob Lemmens

Coen Teunissen

Ine Smeets

Tonny wan den Pasch

Maria van der Heyden

Lia Rijswijck

Collegae ZW-WW
Bulten categorle

Hans, Berend, mama, papa. Frank 


\section{| Curriculum Vitae |}

Personal

Name

Date of birth

Place of birth

Edvcation / wark

$1995-1998$

$1998-2001$ lnge G.P. Duimel-Peeters

September 9,1974

Tongeren, Belgium
Bachelor Programme Physiotherapy

Provinciale Hogeschool Limburg. Hasselt (B)

Thesis: Research and treatment of urine-

incontinence pre- and post-partum [In Dutch].

Master Programme Health Sciences,

Main Subject: Movement Science,

Faculty of Health Sciences, Universiteit Maastricht (NL)

Thesis: The effect of two plant abstracts on the

cell cycle kinetics and induction of apoptosis by

the HCl-ll cell line.

(Department Molecular Cell Biology and

Genetics, Faculty of Medicime. UMD. 
$2001-2004$

$2001-$ May 2005
Post-doctoral Master Programme Epidemiology

EMGO-institute / Department of Clinical

Epidemiology and Biostatistics.

Medical Center, Vrije Universiteit Amsterdam (NL)

Main subjects: Cancer Epidemiology, Public

Health Epidemiology, Prevention - and Incidence

Research

PhD Programme

Faculty of Health Sciences

Department Health Care Studies / Section

Nursing Science

Universiteit Maastricht (NL)

This doctoral thesis.

May-Sept. 2005 Researcher on the 'Resultaten Scoren'-project GGZ Nederland, Amersfoort (NL)

Oct. 2005 - present Staff Advisor Methodology

Ministry of Health, Welfare and Sport

Dutch Health Care Inspectorate, Utrecht (NL) 


\section{| List of Publications |}

Papers 1

Duimel-Peeters IGP, Houwing RH, Teunissen CP, Berger MPF, Snoeckx LHEH, Halfens RJG. A systematic review of the efficacy of topical skin application of Dimethyl Sulfoxide on wound healing and as an anti-inflammatory drug. WOUNDS (A Compendium of Clinical Research and Practice) 2003:15(11):36170.

Duimel-Peeters IGP, Halfens RJG, Berger MPF, Snoeckx LHEH. The effects of massage as a method to prevent pressure ulcers. A review of the literature. Ostomy/Wound Management 2005;51(4):70-80.

Duimel-Peeters 1GP, Hulsenboom MA, Snoeckx LHEH, Berger MPF, Halfens RJG. Massage to prevent pressure ulcers: knowledge, beliefs and practice.

A cross-sectional study among nurses in the Netherlands, in 1991 and 2003. Accepted 2005 (Journal of Clinical Nursing)

Duimel-Peeters IGP, Halfens RJG, Ambergen AW. Houwing RH, Berger MPF. Snoeckx LHEH. The effectiveness of massage with and without dimethyl sulfoxide in preventing pressure ulcers: A randomized, double blind cross-over trial in patients prone to pressure ulcers. Accepted 2005 (International Journal of Nursing Studies)

Duimel-Peeters IGP. Berger MPF, Snoeckx LHEH, Halfens RJG. Policy, knowledge and practice of massage to prevent pressure ulcers in relation to the Dutch prevalence rates. Submitted 2005. 
Duimel-Peeters IGP, Halfens RJG, Berger MPF, Snoeckx LHEH. Massage zur Dekubitusprophylaxe? Teil 1: Richtlinien sind noch nicht genügend in der Praxis angekommen. Pflegezeitschrift 2005;5:318-21.

Duimel-Peeters IGP, Halfens RJG, Snoeckx, LHEH, Berger MPF. Massage zur Dekubitusprophylaxe? Teil 2: Drei Interventionen im Vergleich. Pflegezeitschrift 2005;6:364-67.

Duimel-Peeters IGP, Hulsenboom MA, Halfens RJG. Massage ter voorkoming van decubitus? Een dwarsdoorsnede onderzoek onder verpleegkundigen in Nederland, onderzocht in 1991 en 2003. Tijdschrift voor Verpleegkundigen $2005 ; 1: 43-45$.

Duimel-Peeters IGP, Halfens RJG. De effecten van massage vergeleken met wisselligging. Een gerandomiseerd gecontroleerd onderzoek in verpleeghuizen in Oostelijk-Zuid Limburg. Tijdschrift voor Verpleegkundigen 2005;1:46-49.

1421

Columns |

Duimel-Peeters IGP. Preventing Pressure Ulcers with Massage? Some say it works, others disagree. Ay, there's the rub. Wound Wise Column. Arrerican Jourmal of Nursing 2005:105(8):31-33

\section{Abstracts}

Duimel-Peeters IGP, Houwing RH, Berger, MPF, Snoeckx, LHEH, Halfens RJG. Evaluation of massage with an indifferent cream and massage with a cream that contains Dimethyl Sulphoxide as preventive methods for pressure ulcers. Nederlands-Vlaams Wetenschappelijk Tijdschrift voor Verpleegkundigen $2004: 19(4): 323$. 